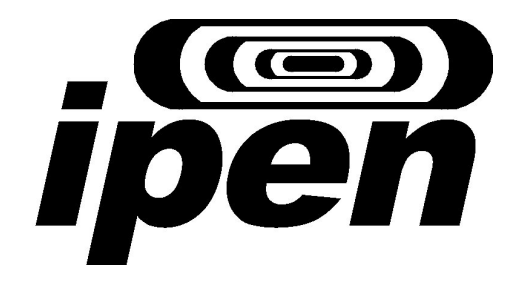

AUTARQUIA ASSOCIADA À UNIVERSIDADE DE SÃO PAULO

\title{
ESTUDO DA APLICAÇÃO DE BIOSSORVENTES NO TRATAMENTO DE REJEITOS RADIOATIVOS LÍQUIDOS CONTENDO AMERÍCIO-241
}

TANIA REGINA DE BORBA

Dissertação apresentada como parte dos requisitos para obtenção do Grau de Mestre em Ciências na Área de Tecnologia Nuclear Aplicações

Orientador:

Dr. Júlio Takehiro Marumo 
Somos responsáveis pelas imagens que criamos na mente dos outros, não apenas através do que falamos, mas igualmente através de tudo aquilo que escrevemos. "Chico Xavier" Fonte: Sinal Verde, 1972. 
Ao Marcos, meu marido, meu maior incentivador e grande apoio para a realização deste trabalho. Aos meus filhos André e Gabriel que também me apoiaram e incentivaram com muito carinho. 
Agradecimentos

Ao Dr. Júlio Takehiro Marumo pela orientação, apoio, confiança e incentivo constantes.

À Dra. Solange Kazumi Sakata pelas sugestões, discussões, auxílio, dedicação e paciência.

À Dra. Maria Helena Bellini Marumo pelas discussões, auxílio, apoio e incentivo.

Ao Marcos, meu marido, que esteve presente em todos os momentos, incentivando, apoiando, ajudando e, principalmente acreditando no meu potencial.

Ao Dr. Roberto Vicente pelo apoio, sugestões e discussões.

A amiga Maria Helena Tirollo Taddei, da CNEN de Poços de Caldas, pela colaboração e apoio técnico.

Ao MSc. Rafael Vicente de Pádua Ferreira pelo auxílio, apoio, incentivo e dedicação constantes.

Ao Dr. Durvanei Augusto Maria, do Instituto Butantan, pelo auxílio e dedicação.

Ao Dr. Ronaldo Biondo e Dra. Elisabete José Vicente do Laboratório do Genética de Micro-organismos do Instituto de Biociências da Universidade de São Paulo/SP, pela colaboração.

A todos os amigos do Laboratório de Rejeitos Radioativos, pelas gentilezas, apoio, companheirismo e bons momentos. 


\section{RESUMO}

$O$ uso da energia nuclear para as mais diversas finalidades tem se intensificado e destacado pelos benefícios que proporciona. A medicina diagnóstica e terapêutica, a agricultura, a indústria, a geração de energia elétrica, são alguns exemplos. Entretanto, o uso da energia nuclear gera rejeitos radioativos e estes requerem tratamento adequado para garantir a segurança ambiental e dos seres vivos. A biossorção e bioacumulação representam uma alternativa emergente, para 0 tratamento de rejeitos radioativos líquidos, proporcionando redução de volume e mudança de estado físico. Este trabalho teve como objetivos estudar biossorventes para promover o tratamento de rejeitos líquidos contendo Amerício-241, proporcionando redução de volume e mudando seu estado físico para sólido. Os biossorventes avaliados foram: Saccharomyces cerevisiae imobilizadas em alginato de cálcio, Saccharomyces cerevisiae livres e inativadas, alginato de cálcio, Bacillus subtilis, Cupriavidus metallidurans e Ochrobactrum anthropi. Os resultados foram bastante satisfatórios, chegando a $100 \%$ em alguns casos. Esta técnica parece viável para a implantação no Laboratório de Rejeitos Radioativos do IPEN - CNEN/SP a curto prazo, por ser simples e de baixo custo.

Palavras Chave: Amerício-241, biossorção, bioacumulação, bactérias. 


\begin{abstract}
The use of nuclear energy for many different purposes has been intensified and highlighted by the benefits that it provides. Medical diagnosis and therapy, agriculture, industry and electricity generation are examples of its application. However, nuclear energy generates radioactive wastes that require suitable treatment ensuring life and environmental safety. Biosorption and bioaccumulation represent an emergent alternative for the treatment of radioactive liquid wastes, providing volume reduction and physical state change. This work aimed to study biosorbents for the treatment of radioactive liquid wastes contaminated with americium-241 in order to reduce the volume and change the physical state from liquid to solid. The biosorbents evaluated were Saccharomyces cerevisiae immobilized in calcium alginate beads, inactivated and free cells of Saccharomyces cerevisiae, calcium alginate beads, Bacillus subtilis, Cupriavidus metallidurans and Ochrobactrum anthropi. The results were quite satisfactory, achieving $100 \%$ in some cases. The technique presented in this work may be useful and viable for implementing at the Waste Management Laboratory of IPEN - CNEN/SP in short term, since it is an easy and low cost method.
\end{abstract}

KEYWORDS: Americium-241, biosorption, bioaccumulation, bacteria. 


\section{SUMÁRIO}

PÁGINA

1. INTRODUÇÃO

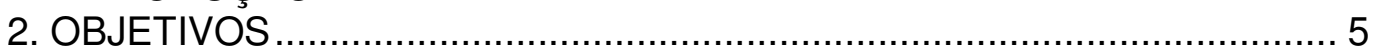

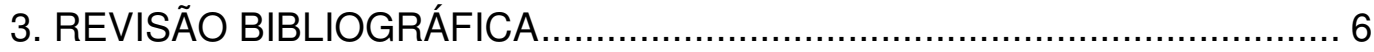

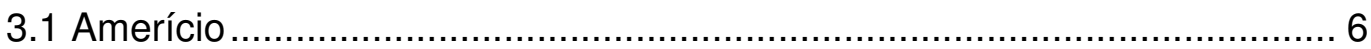

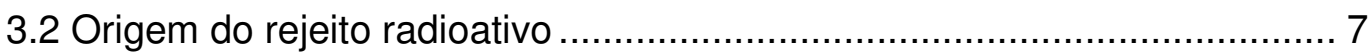

3.3 Gerenciamento de rejeitos radioativos ............................................... 9

3.4 Mecanismos de remoção de metais pesados ........................................ 10

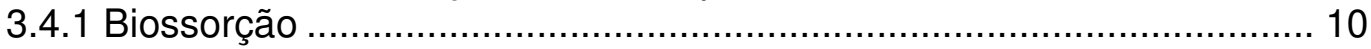

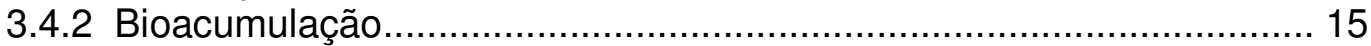

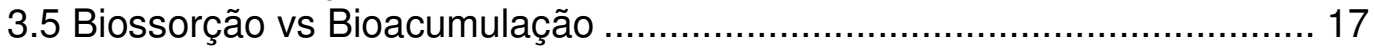

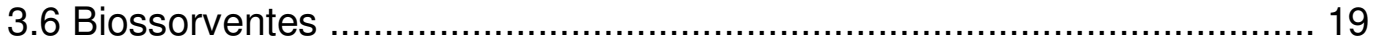

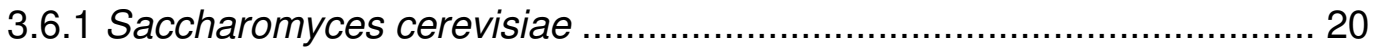

3.6.2 Alginato de sódio................................................................... 22

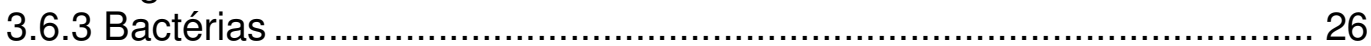

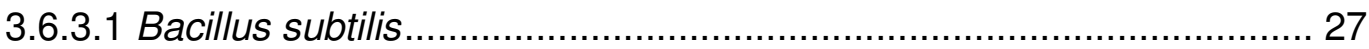

3.6.3.2 Cupriavidus metallidurans ....................................................... 29

3.6.3.3 Ochrobactrum anthropi .................................................................. 30

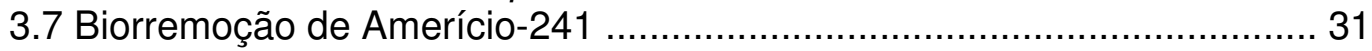

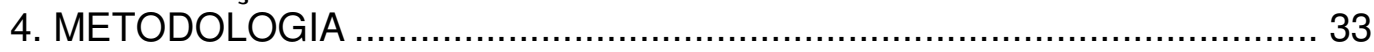

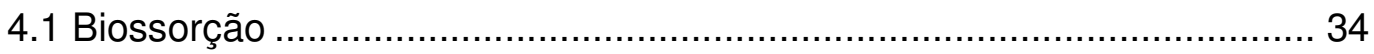

4.1.1 Biossorção por Saccharomyces cerevisiae livres ............................... 34

4.1.2 Biossorção por Saccharomyces cerevisiae imobilizadas em micro esferas de

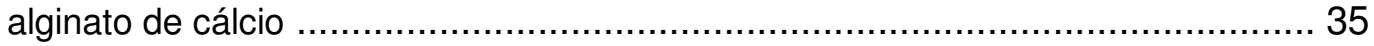

4.1.3 Biossorção por micro esferas de alginato de cálcio ............................. 36

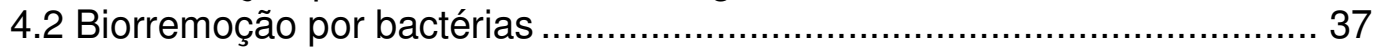

4.2.1 Cultura de bactérias ................................................................. 37

4.2.2 C.I.M. - Concentração Inibitória Mínima …………………………..... 38

4.3 Curvas de crescimento das bactérias ................................................. 40

4.4 Viabilidade celular ...................................................................... 40

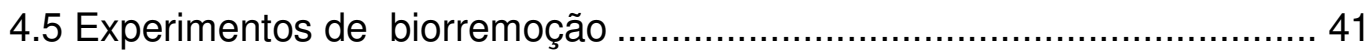

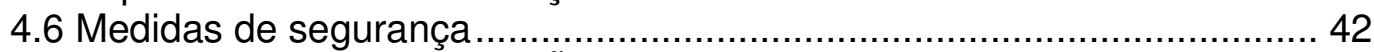

5. RESULTADOS E DISCUSSÕES ....................................................... 43

5.1 Resultados da viabilidade celular de Saccharomyces cerevisiae inativadas

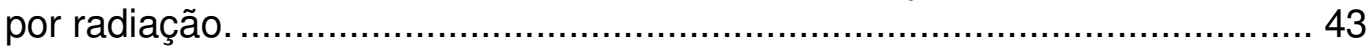

5.2Resultados de Biossorção ........................................................... 43

5.2.1Biossorção de ${ }^{241} \mathrm{Am}$ por Saccharomyces cerevisiae livres inativadas .. 43 5.2.2 Biossorção de ${ }^{241} \mathrm{Am}$ por alginato de cálcio e por Saccharomyces

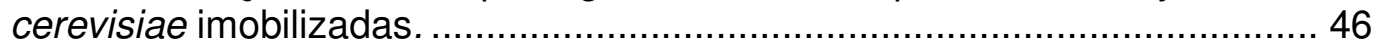

5.3 Testes preliminares realizados com bactérias ..................................... 50

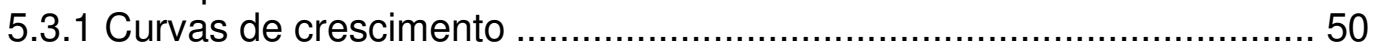

5.3.2 Concentração Inibitória Mínima....................................................... 51

5.3.3 Testes de viabilidade celular ....................................................... 52

5.4 Resultados de biorremoção ........................................................... 54

5.4.1 Biorremoção por Ochrobactrum anthropi ........................................... 54

5.4.2 Biorremoção por Cupriavidus metallidurans ………………………... 55

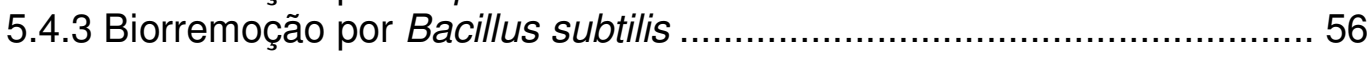


6. CONCLUSÕES

59

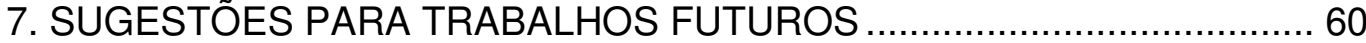

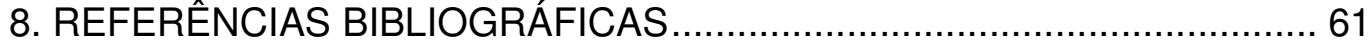




\section{INTRODUÇÃO}

O avanço da ciência e da tecnologia desde a revolução industrial tem aumentado a capacidade do ser humano em explorar os recursos naturais. A introdução repentina e frequente de compostos químicos em diferentes ecossistemas alterando a capacidade de auto-limpeza dos mesmos, resultando no acúmulo de contaminantes a níveis problemáticos e até prejudiciais.

A contaminação do ambiente com metais tóxicos e radioisótopos surge como resultado da atividade humana (CAÑIZARES-VILLANUEVA, 2000). Esses poluentes, mesmo em baixas concentrações não se degradam, e tendem a circular e permanecer por longo tempo no ambiente, além de se acumularem através da cadeia alimentar, o que cria sérios problemas de saúde pública (MACHADO, 2008).

Os radioisótopos têm sido amplamente utilizados na indústria, agricultura, medicina e, principalmente na área da pesquisa. $\mathrm{O}$ custo da utilização desta tecnologia para a sociedade é a geração de rejeitos radioativos.

Os rejeitos radioativos necessitam ser tratados apropriadamente para garantir a segurança do homem e do meio ambiente, cabendo à gerência de rejeitos radioativos esse papel. Compreende-se por gerência de rejeitos radioativos, o controle dos rejeitos radioativos que envolvem uma série de atividades operacionais e administrativas, tais como: coleta, segregação, prétratamento, tratamento, acondicionamento, armazenagem temporária, transporte e deposição final (MARUMO, 1997).

As técnicas convencionais de remoção de íons metálicos de soluções, tais como a precipitação, troca iônica e processos eletroquímicos nem sempre são adequadas para o tratamento de rejeitos radioativos devido aos grandes volumes de rejeitos, baixas concentrações de íons metálicos em soluções aquosas e por razões econômicas. Em muitos países esses rejeitos são tratados por incineração, que destrói os compostos orgânicos perigosos e os radionuclídeos 
presentes são capturados pelas cinzas volantes ou liberados com os gases (STRINGFELLOW et al., 2000).

No Brasil, não há incineradores disponíveis para a queima de rejeitos radioativos. Apesar do volume de geração anual desses rejeitos ser baixo, da ordem de 0,2 $\mathrm{m}^{3}$ numa instituição como o IPEN, é necessário desenvolver métodos de tratamento que possam ser aplicados eficientemente a um baixo custo. Dos fluxos de rejeitos, os líquidos merecem atenção especial, pois os processos de tratamento disponíveis são, muitas vezes, caros e operacionalmente difíceis. Buscar novas alternativas de tratamento desses rejeitos que aliem baixo custo e eficiência é uma tarefa importante e difícil, já que, nesse caso, cuidados adicionais devem ser considerados por se tratar de rejeitos radioativos, que estão em estado físico de fácil dispersão.

A pesquisa de novas técnicas envolvendo a remoção de radionuclídeos de rejeitos tem dirigido atenções para a biossorção (AKHTAR et al., 2008; TSEZOS, 2001 e AHALYA et al., 2003), que é um processo no qual biomassa é usada na remoção de metais tóxicos de uma solução (GADD, 1993).

Esta técnica é considerada uma alternativa biotecnológica de baixo custo para o tratamento de grandes volumes e baixas concentrações de metais, de 1 a $100 \mathrm{mg} / \mathrm{L}$ presentes em rejeitos líquidos contendo variados radionuclídeos.

Os mecanismos da biossorção de metais tóxicos são complexos e podem ser resumidos em quelação, adsorção na superfície da célula por forças físicas e acumulação extracelular e intracelular (VOLESKY e HOLAN, 1995; AHALYA et al., 2007).

Como exemplo de biossorventes pode-se citar as algas (FENG et al., 2004), bactérias (MURALEEDHARAN et al., 1991), fungos (KAPOOR et al., 1999) e leveduras (BAYAN et al., 2001). A habilidade com que, em soluções diluídas, os micro-organismos concentram os íons metálicos em sua estrutura celular fez com que estes fossem os mais estudados na remoção de vários metais, como o Cu, $\mathrm{Cd}, \mathrm{Pb}, \mathrm{U}, \mathrm{Am}, \mathrm{Ce}, \mathrm{Cs}$ e Ni, entre outros (VOLESKY, 1994).

Entre os biossorventes mais promissores para remoção de metais pesados, que foram estudados nas últimas décadas, a levedura Saccharomyces cerevisiae tem recebido uma atenção cada vez maior devido à sua natureza singular (WANG e CHEN 2006). A Saccharomyces cerevisiae, destaca-se como biossorvente por ser um subproduto das indústrias de alimento e destilarias, 
possuírem baixo custo, facilidade de manuseio, além de sequenciamento genético conhecido. A levedura Saccharomyces cerevisiae é um fungo unicelular e eucariótico com capacidade de biossorção conferida pelos componentes celulares e, segundo Brady e Dukan, (1984), pela parede celular, o que conferiria um sítio adicional em relação a outros organismos desprovidos de parede celular. Devido a esta capacidade de retirar metais da água, ela pode ser usada como bioacumulador desses metais, sendo uma ótima alternativa para a descontaminação ambiental (BASÍLIO et al., 2005).

Há diversos estudos desta levedura nas mais diferentes formas que auxiliaram na compreensão do mecanismo de retirada de diversos metais tóxicos como o $\mathrm{Pb}, \mathrm{Cu}, \mathrm{Cd}, \mathrm{Hg}, \mathrm{Am}, \mathrm{U}, \mathrm{Ni}, \mathrm{Zn}$, entre outros (WANG e CHEN, 2006, LIU et al., 2002-b). É digno de nota que estudos de biossorção/bioacumulação, demonstraram que a Saccharomyces cerevisiae pode diferenciar metais baseados na sua toxidade e que apresenta mais afinidade com $\mathrm{U}, \mathrm{Pb}, \mathrm{Hg}$ do que $\mathrm{Cu}, \mathrm{Ni}$ e outros metais. Foi demonstrado que a capacidade de acumular $\mathrm{U}$ e $\mathrm{Zn}$ em células mortas de Saccharomyces cerevisae é $40 \%$ maior quando comparada à biomassa viva (VOLESKY e PHILLIPS, 1995).

Muitos dos biossorventes são utilizados na forma imobilizada quando se trata de grande volume de efluentes contaminados por metais pesados. Um material inerte age como suporte na biomassa formando uma estrutura sólida que é quimicamente estável e facilita o processo de separação entre o biossorvente e o resíduo líquido. As técnicas mais comuns de imobilização baseiam-se na adsorção, na formação de ligações iônicas e covalentes e no enclausuramento em matrizes poliméricas (VEGLIO e BEOLCHINI, 1997; LEE, 1981).

Segundo Gomes et al. (2007) que estudaram a imobilização de Saccharomyces cerevisiae em diferentes suportes para remoção de cádmio, o melhor suporte para a imobilização desta levedura é o alginato de cálcio, por sua estabilidade e capacidade de retenção de $90 \%$ do metal.

O alginato é um copolímero linear de a-L-guloronate e a-D-mannuronate, que constitui de 10 a $40 \%$ do peso seco de todas as algas marrons e apresenta a capacidade de formar géis estáveis biodegradáveis na presença de cátions (PAPAGEORGIOU, 2006). É frequentemente utilizado para imobilização de células e, além disso, na forma de esferas, o alginato de cálcio pode ser facilmente removido de uma solução de modo semelhante ao das resinas de troca 
iônica. Sua capacidade isolada de biossorção também tem sido estudada (IBÁÑ̃EZ, 2002; OZDEMIR, 2005).

A bioacumulação caracteriza-se pelo uso da habilidade que células ou micro-organismos vivos têm de absorver metais de uma solução (KADUKOVÁ, 2005).

O uso de biomassa microbiana com a finalidade de detoxificação de efluentes industriais para proteção ambiental e recuperação de metais valiosos por meio da biossorção disponibiliza uma tecnologia alternativa potencial (GADD, 2000 e LLOYD, 2003).

Os processos microbianos para remoção de metais tóxicos de fluxos de resíduos empregam células de biomassa vivas, não vivas, ou biopolímeros como biossorventes (KOTRBA, et al., 1999).

Desta forma, a biossorção e/ou a bioacumulação podem ser considerados métodos viáveis de baixo custo, fácil aplicação e eficientes para tratamento de rejeitos radioativos líquidos armazenados na Gerência de Rejeitos Radioativos do IPEN-CNEN/SP. Esses rejeitos contêm ${ }^{137} \mathrm{Cs},{ }^{241} \mathrm{Am},{ }^{235},{ }^{238} \mathrm{U}$ e produtos de fissão e são provenientes, principalmente, de centros de pesquisa, incluem óleos lubrificantes e solventes utilizados em experimentos em geral e operações de descontaminação. A implantação destes processos para tratamento de rejeitos radioativos requer um estudo detalhado dos parâmetros que envolvem este processo. 


\section{OBJETIVOS}

Este trabalho tem como objetivos avaliar o potencial dos seguintes biossorventes: alginato de cálcio, Saccharomyces cerevisiae inativadas livres e imobilizadas em alginato de cálcio, além das bactérias Ochrobactrum anthropi, Cupriavidus metallidurans e Bacillus subtilis livres, na remoção de ${ }^{241} \mathrm{Am}$ presente em rejeito líquido, além de promover o tratamento de rejeito líquido contendo ${ }^{241} \mathrm{Am}$, reduzindo volume e transformando o rejeito líquido em sólido. 


\section{REVISÃO BIBLIOGRÁFICA}

\subsection{Amerício}

Como um elemento transurânico, o Amerício tem cerca de 20 radioisótopos ou isômeros. Entre eles, o ${ }^{241} \mathrm{Am}\left(\mathrm{T}_{1 / 2}=433\right.$ anos, $\mathrm{E \alpha}=5.468 \mathrm{MeV}, 86,6 \% ; 5.443$ Mev, 12,3\%; $E_{Y}=0,0596 \mathrm{MeV}, 35 \%$ ), é o mais importante, porém não é usado exclusivamente na indústria nuclear, mas seu uso é amplo em outros campos. Por exemplo, muitos dos alarmes de incêndios de hotéis, hospitais e outros centros de serviços contêm uma fonte de ${ }^{241} \mathrm{Am}$ (LIU et al., 2002-b).

O amerício é um elemento da série dos actinídeos, possui número atômico 95, imediatamente posterior ao plutônio. Foi isolado pela primeira vez em 1944 por Seaborg e seus colaboradores (KELLER, 1971 apud CLAIN, 1999).

O ${ }^{241} \mathrm{Am}$ é resultante de sucessivas capturas de nêutrons pelo $\mathrm{Pu}^{239}$, conforme as reações:

${ }^{239} \mathrm{Pu}(\mathrm{n}, \mathrm{y}) \rightarrow{ }^{240} \mathrm{Pu}(\mathrm{n}, \mathrm{\gamma}) \rightarrow{ }^{241} \mathrm{Pu} \quad \stackrel{\beta^{-}}{\rightarrow}{ }^{241} \mathrm{Am}$

Posteriormente, a produção deste radioisótopo foi confirmada pelo bombardeamento do ${ }^{238} \mathrm{U}$ com partículas alfa, segundo as reações:

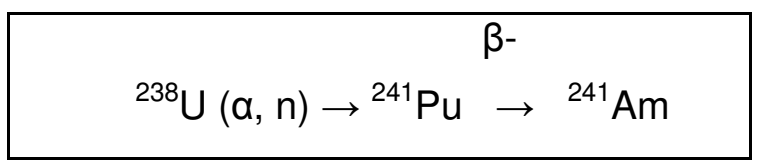

As partículas a resultantes do processo de decaimento do ${ }^{241} \mathrm{Am}$ oferecem reduzido risco por radiação externa, devido ao fato de apresentarem um alcance máximo de $4 \mathrm{~cm}$ e, no tecido humano, somente alguns milésimos de milímetro. Em relação à radiação gama, 2 a $3 \mathrm{~cm}$ de tecido do corpo humano são suficientes para reduzir em 50\% o número de fótons (MIRANDA e VICENTE, 1999 apud MARUMO, 2006). 
Infelizmente $0{ }^{241} \mathrm{Am}$ é um dos contaminantes mais perigosos devido à sua alta toxicidade e meia-vida longa. Se $0{ }^{241} \mathrm{Am}$ for absorvido pelo corpo humano, fixa-se principalmente nos ossos e fígado. A dose máxima permitida ou concentração de ${ }^{241} \mathrm{Am}$ no corpo humano ou na água é de $11,1 \mathrm{kBq}$ (aproximadamente $\left.8.76 \times 10^{-8} \mathrm{~g}\right)$ e $1,48 \mathrm{~Bq} / \mathrm{mL}\left(\sim 1.17 .10^{-6} \mathrm{~g} / \mathrm{L}\right)$, respectivamente (BENEDICT, 1981 apud LIU, 2002-b).

\subsection{Origem do rejeito radioativo}

A radioatividade é um fenômeno natural e fontes naturais de radiação são características do ambiente. Radiação e substâncias radioativas têm muitas aplicações benéficas, que vão desde a geração de energia para usos na indústria, medicina e agricultura. Os riscos da radiação para os trabalhadores, o público e ao meio ambiente que podem surgir a partir destas aplicações têm de ser avaliados e, quando necessário, controlados (IAEA, 2009).

A liberação de radionuclídeos de locais contaminados e sua subsequente mobilidade no meio ambiente é objeto de grande interesse público (MERROUN, 2008).

Significativas quantidades de radionuclídeos naturais ou artificiais/sintéticos foram liberados como consequência de testes nucleares nas décadas de 50 e 60, e também após o acidente nuclear de Chernobyl em 1986 (LLOYD e RENSHAW, 2005).

Existe a expectativa de que, no futuro, o uso da energia nuclear para a geração de eletricidade e outros propósitos aumente e substitua as fontes convencionais de energia (figura 1). De acordo com as estimativas da Agência Internacional de Energia Nuclear, até 2030, haverá um crescimento significativo do uso da eletricidade e a energia nuclear terá de expandir-se (IAEA, 2009). 


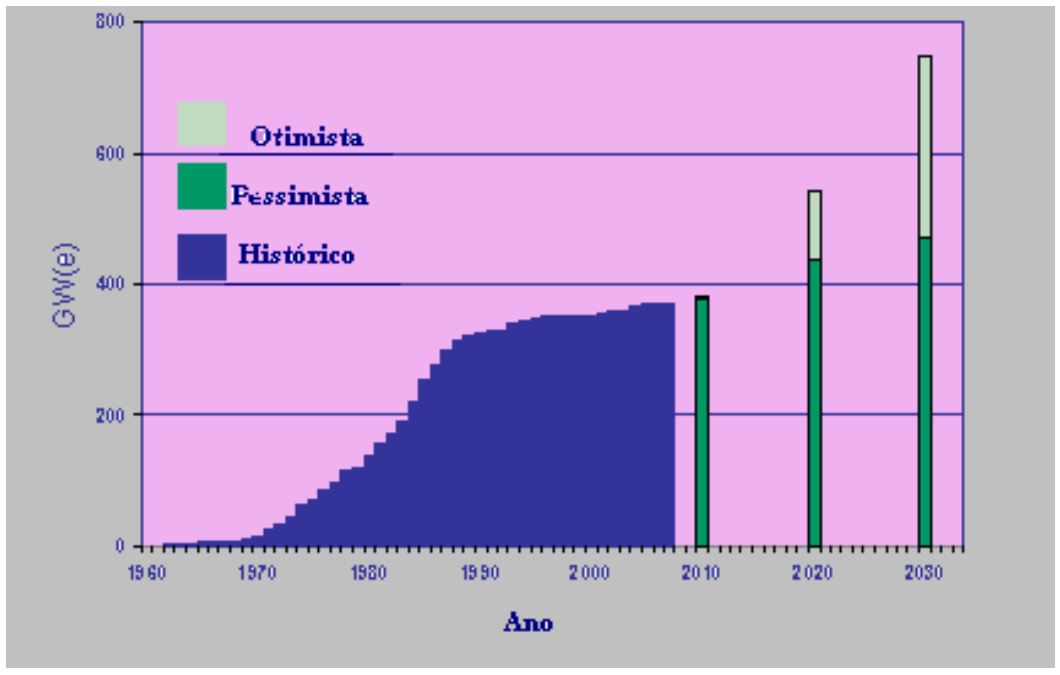

Figura 1- Gráfico: Histórico e estimativas otimista e pessimista de produção de energia elétrica a partir de usinas nucleares. Fonte: IAEA, 2009.

A produção de energia nuclear, no entanto, está inevitavelmente associada a produção de rejeitos radioativos dos vários estágios do ciclo nuclear (IAEA, 2009). Entre os rejeitos líquidos, os de altos níveis são gerados durante o processo de uso do combustível e, contém produtos de fissão e radionuclídeos emissores a de longa vida (ATBACK et al., 1992 apud VENKOBACHAR et al., 1995).

As soluções provenientes do $1^{\circ}$ ciclo do reprocessamento do combustível de usinas nucleares baseado no processo Purex, contém mais de 99,7\% de produtos de fissão não voláteis e o restante em actinídeos tais como o neptúnio, amerício e Cúrio e, também, o urânio e o plutônio residuais. Além disso, estão presentes o ferro, crômio, níquel, alumínio, zircônio e magnésio, materiais provenientes da corrosão dos equipamentos de processo e de revestimento do elemento combustível durante a dissolução do mesmo. Esse efluente líquido caracterizado pelo alto nível de radioatividade gama, alta liberação de calor e presença de nuclídeos emissores alfa de meia-vida longa é classificado como rejeito líquido de alta atividade (HLLW- High Level Liquid Waste) e contém mais de $95 \%$ da radioatividade total do combustível irradiado (YAMAURA, 1999).

Hospitais, clínicas, indústrias, institutos ou centros de pesquisa também geram rejeitos radioativos, embora, em termos de volume e peso de material, todo 
setor nuclear produza muito menos rejeito do que outras atividades industriais ou não industriais (MOURA, 2008).

A Agência Internacional de Energia Atômica define rejeito radioativo como "material que contém ou que está contaminado com radionuclídeos em concentrações ou níveis de atividade maiores que os limites de isenção estabelecidos pela autoridade competente" (IAEA, 1988). No Brasil, a Comissão Nacional de Energia Nuclear define rejeito radioativo como: "qualquer material resultante de atividades humanas, que contenha radionuclídeos em quantidades superiores aos limites de isenção especificados na Norma CNEN-NE-6.02 Licenciamento de Instalações Radioativas, e para o qual a reutilização é imprópria ou não prevista" (CNEN, 1985). Esta norma ainda estabelece os critérios de classificação dos rejeitos que são baseados no estado físico, na natureza da radiação, na concentração e na taxa de exposição (CNEN, 1985). Considerando estes critérios, os rejeitos são subdivididos de acordo com os níveis de radiação, sendo, desta maneira, classificados como rejeitos de nível baixo, médio ou alto.

O acúmulo de rejeitos radioativos é uma grande preocupação, no que diz respeito à sua disposição. A maioria dos resíduos radioativos é gerada no funcionamento dos reatores nucleares, instalações de produção/enriquecimento de combustível e instalações de reprocessamento de combustível. Além disso, os laboratórios de radioquímica envolvidos em trabalhos de pesquisa e controle de qualidade geram resíduos radiotóxicos. Os resíduos aquosos gerados contêm diversas impurezas iônicas com componentes metálicos radiotóxicos (DAS et al., 2002).

\subsection{Gerenciamento de rejeitos radioativos}

A gerência de rejeitos radioativos compreende o conjunto de atividades relativas ao rejeito, seja administrativo ou operacional, que corresponde às etapas de coleta, segregação, pré-tratamento, acondicionamento, armazenagem temporária, transporte e deposição final. Cabe à gerência zelar por estes rejeitos enquanto considerados fonte potencial de perigo. A redução do volume e o acondicionamento são duas etapas importantes da gerência porque estão 
relacionadas ao custo de armazenamento e segurança física e radiológica (MARUMO, 2006).

A estratégia de gerenciamento de rejeitos, prevê a separação de radionuclídeos de longa vida e sua transmutação para os de curta vida de modo a reduzir o risco potencial e o custo da construção de repositórios. Um grande volume de resíduos e de concentração muito baixa de metais (de 2 a $50 \mathrm{mg} \cdot \mathrm{dm}^{-3}$ ) restrito a viabilidade dos processos de separação convencionais que são caros e elaborados, requer equipamentos caros e de operação de alto custo, além de energia (DAS, et al.,2002).

\subsection{Mecanismos de remoção de metais pesados}

\subsubsection{Biossorção}

O termo biossorção é usado para descrever a remoção de metais pesados e/ou radionuclídeos independente da atividade metabólica celular e, portanto, passiva. A descoberta e o desenvolvimento da biossorção fornecem base para uma tecnologia que visa a retirada de metais pesados de soluções com concentrações metálicas diluídas no intervalo de 1 a 100 mg/L (VOLESKY e CHONG, 1995). É um processo no qual se utiliza sólidos de origem vegetal ou micro-organismos na retenção, remoção ou recuperação de metais pesados de um ambiente líquido (COSSICH et al., 2000).

O estudo de Adams e Holmes em 1935 (apud VOLESKY e HOLAN, 1995) representa não somente o limiar da troca iônica na química, como também uma tentativa inicial de biossorção. Estes autores descreveram a remoção de íons de cálcio e magnésio pela resina de tanino da casca de acácia-negra (Acácia mollissima).

Os primeiros estudos sobre biossorção foram realizados no início da década de 80 por Volesky e Tsezos quando pesquisaram sobre a biossorção do urânio e tório (VOLESKY, 2007).

Recentemente, a tecnologia da biossorção tem sido reconhecida como atrativa para a remoção de metais pesados e degradação de compostos químicos orgânicos presentes em rejeitos líquidos. De fato, no início dos anos 50 houve 
algumas tentativas de acumular metais preciosos, tais como ouro, prata e cobre por diversos micro-organismos. Mas, somente a partir década 80 que houve um crescente interesse na remoção de materiais nocivos e tóxicos presentes em águas residuais para proteção ambiental (TSEZOS, 1988 apud LIU et al., 2003).

As primeiras referências ao mecanismo de biossorção foram citadas por Rothstein et al. em 1948, eles apresentaram evidências de que o urânio age sobre a superfície celular de leveduras "por complexação de grupos desconhecidos associados ao metabolismo de glucose" (VOLESKY, 1990).

O conceito de biossorção foi usado em 1949 por Ruchhoft que obteve a remoção de ${ }^{239} \mathrm{Pu}$ em água por lodo ativado, com cerca de $60 \%$ remoção, usando uma única fase de tratamento (VOLESKY, 1990).

No início do ano de 1986, em uma reunião organizada pela Solvent Engineering Extration and Íon Exchange Group of the Society of Chemical Industry no Reino Unido, a biossorção foi reconhecida como uma tecnologia emergente.

Foi somente na década de 90 que a biossorção surge como uma nova área científica que poderia auxiliar a recuperar metais pesados e considerada como um candidato ideal para tratamento de grandes volumes de baixas concentrações de rejeitos líquidos complexos (VEGLIO et al., 1997; VOLESKY, 1990).

A pesquisa sobre biossorção tem como foco os três principais campos: os biossorventes, os mecanismos de biossorção e a sua aplicação em larga escala.

Os primeiros relatos descreveram os biossorventes como abundantes materiais biológicos que poderiam ser utilizados para remover até pequenas quantidades de metais pesados de efluentes industriais, a muito baixo custo (VIEIRA e VOLESKY, 2000), dentre eles, estão os diversos materiais naturais ou de origem biológica, incluindo bactérias, fungos, leveduras, algas, e outros.

O uso de micro-organismos inativos torna-se uma vantagem em relação ao uso de micro-organismos vivos, uma vez que não sofrem limitações devido à toxicidade do meio e não requerem renovação do meio de cultura (KIRAN et al., 2005). Esses biosorventes possuem a propriedade de sequestrar metais e reduzir a concentração de íons de metal presentes em soluções de baixas concentrações, porém, é necessário continuar pesquisando os tipos mais promissores de biomassa de uma variedade extremamente grande que possa ser 
prontamente avaliado e biomateriais de baixo custo (KRATOCHVIL e VOLESKY, 1998).

O mecanismo de biossorção não é completamente compreendido. É necessário identificar o mecanismo de remoção dos metais pelos biossorventes e entender a interação metal-biossorvente.

Embora a biossorção seja uma técnica potencialmente comprovada para a remoção de metais de soluções aquosas em escala laboratorial, sua performance sob condições industriais reais, ainda é um desafio (VIJAYARAGHAVAN e YUN, 2008).

Muitas pesquisas têm sido realizadas com o objetivo de melhorar o processo de biossorção, incluindo imobilização de biomateriais, melhoramento, reuso e otimização do processo de biossorção (WANG e CHEN, 2006).

Em relação aos biossorventes, alguns biomateriais com alta capacidade de se ligarem a metais, têm sido identificados. Entre eles, algas marinhas (ex. Sargassum natans), bactérias (ex. Bacillus subtilis), fungos (ex. Rhizopus arrhizus), leveduras (ex. Saccharomyces cerevisiae) e biomassa microbiana originada de rejeitos de indústrias alimentícias. Por razões econômicas, os pesquisadores têm dedicado muita atenção a vários subprodutos da indústria de fermentação porque sua produção ocorre em larga escala. A aplicação de microorganismos presentes nestes rejeitos como biossorventes para biossorção de metais pesados e radionuclídeos apresentaria vantagem dupla, pois utiliza resíduos para tratar resíduos (WANG e CHEN, 2006).

A biossorção de metais é baseada em mais de um mecanismo. Ela consiste de vários mecanismos que diferem quantitativa e qualitativamente de acordo com as espécies usadas, a origem da biomassa e até mesmo o seu processamento. Segundo Kapoor e Viraraghavan (1995), o sequestro de íons metálicos pelas paredes celulares ocorre por meio de dois mecanismos, um pela ligação direta nos grupos funcionais e o outro, pela interação físico-química, troca iônica e sorção química, pelo fenômeno conhecido por adsorção. Enquanto que a quelação e a adsorção dependem de processos físico-químicos entre os íons metálicos e os grupos funcionais da superfície da célula, a acumulação intracelular é associada a uma etapa não metabólica de biossorção dos íons metálicos pelos sítios ligantes da estrutura celular e, outra, na qual estes íons passam pela membrana celular através de ciclos metabólicos celulares e, 
portanto é um processo mais lento e que necessita de células viáveis (MALIK, 2004).

Existem diversos grupos funcionais que poderiam atrair e reter metais na biomassa: grupos de acetamido da quitina, polissacarídeos estruturais de fungos, grupos amino e fosfato em ácidos nucléicos, amido, sulfidril e carboxil em proteínas, grupos hidroxil em polissacarídeos, e principalmente carboxil e sulfatos em polissacarídeos de algas marinhas. Entretanto, a presença de alguns grupos funcionais não garante sua acessibilidade aos metais pesados ou radionuclídeos (VOLESKY e HOLAN, 1995).

As paredes das bactérias, algas e fungos são eficientes biossorventes metálicos. Em muitos casos, a ligação inicial pode ser seguida pela deposição inorgânica de quantidades crescentes de metais. A biossorção pode envolver ligações iônicas e covalentes, com constituintes como proteínas e polissacarídeos. As variações na composição das paredes celulares das células dos micro-organismos podem sofrer influências das condições de cultura, resultando em variações consideráveis na capacidade biossortiva e permitir algum grau de acumulação seletiva (GADD, 1990).

Os mecanismos pelos quais micro-organismos removem metais de solução são: acumulação extracelular/precipitação; sorção na superfície celular ou complexação e acumulação intracelular.

Existem basicamente duas categorias de rejeitos industriais líquidos que requerem tratamento prévio para descarte: aqueles que contêm grandes volumes de baixas concentrações (<100 mg. ${ }^{-1}$ ) e os que possuem pequenos volumes de altas concentrações de totais de sólidos dissolvidos. Para o primeiro caso, uma alta afinidade do biossorvente com o contaminante torna-se obrigatória, enquanto que no último caso, o biossorvente requer alta capacidade de captação (ATKINSON e KASAN, 1998).

Poucos são os exemplos de biossorventes comercialmente utilizados. Um deles, é o processo desenvolvido pela AMT-Bioclaim ${ }^{\mathrm{TM}}$, o qual utiliza bactérias Bacillus subtilis tratadas com solução cáustica forte, lavadas e imobilizadas em esferas porosas de polietilenoimina e glutaraldeído. Este biossorvente comercial é capaz de acumular ouro, cádmio e zinco de soluções e também poderia ser adequado para muitas operações que utilizam metais (BRIERLEY, 1990 apud VIJAYARAGHAVAN e YUN, 2008). 
O AlgaSORB $^{\mathrm{TM}}$, é outro biossorvente comercial feito com algas ( $C$. vulgaris) inativas e imobilizadas em matriz de sílica em gel, que reduz os níveis de cádmio e mercúrio a níveis abaixo dos especificados para padrões de água potável (ATKINSON e KASAN, 1998).

Dois outros biossorventes comerciais são: $M^{2 t a G e n e}{ }^{R}$ e RAHCO BioBeads, têm mostrado efetiva remoção de íons de metais pesados quando aplicados em galvanoplastia e resíduos de fluxos de mineração, embora haja pouca informação sobre a aplicação industrial de ambos (ATKINSON e KASAN, 1998).

O biossorvente BIO-FIX é composto por uma variedade de biomassas, incluindo bactérias, fungos, musgos e algas, imobilizados em polissulfona de alta densidade. Este biossorvente exibe seletividade de metais pesados tóxicos sobre metais alcalinos terrosos (VIJAYARAGHAVAN e YUN, 2008).

Atkinson e Kasan (1998) e Arief et al. (2008), relacionaram questões que deveriam ser consideradas para a viabilidade do potencial de um biossorvente para a remoção de metais de efluentes industriais. Eles incluem as características dos efluentes, tais como volume, tipo de contaminante e competitividade de íons, solução química, ajuste de $\mathrm{pH}$ e temperatura; características da biomassa, tais como disponibilidade, estabilidade mecânica, habilidade de regeneração, especificidade do contaminante e cinética da reação; e características do processo, tais como capital e custos de operação, batelada/fluxo contínuo e espaço necessário.

O sucesso da tecnologia de biossorção não depende apenas do potencial de biossorção, mas também do suprimento contínuo da biomassa para o processo (TSEZOS, 2001).

Para que a biossorção seja aplicada em escala industrial, é necessário que a biomassa tenha um custo atrativo.

Biossorventes econômicos, em larga escala, podem ser definidos como materiais que são abundantes na natureza ou que podem ser encontrados como subprodutos ou resíduos industriais e que normalmente não requerem prétratamento (ARIEF, et al., 2008).

A biossorção é uma alternativa para a remoção de íons de metais pesados, aos métodos existentes, de baixo custo e a biomassa disponível naturalmente, pode ser utilizada (SHEKHAR et al., 2003). 


\subsubsection{Bioacumulação}

Os micro-organismos se adaptaram a viver em praticamente todos os ambientes aquáticos e terrestres encontrados na Terra, incluindo os ambientes contaminados com radioatividade, e por este motivo, têm o potencial de interagir com uma ampla gama de materiais radioativos (tanto em solução quanto em fases insolúveis) através da produção de uma variedade de metabólitos e biomoléculas. Tais interações podem alterar significativamente a composição química de radionuclídeos e assim seu impacto no meio ambiente (RENSHAW et al., 2007).

A bioacumulação caracteriza-se pela acumulação ativa de metais por células vivas. Este processo é dependente da atividade metabólica da célula, a qual pode ser significativamente afetada pela presença de íons metálicos. A tolerância aos metais deve refletir a habilidade de um organismo sobreviver em ambientes com altas concentrações de metais ou de acumular metais sem resultar em sua morte (VOLESKY, 1990).

A bioacumulação de pesticidas e outras substâncias químicas em organismos aquáticos obteve atenção na década de 60. Resíduos de DDT (diclorodifeniltricloroetano), DDD (diclorodifenildicloroetano), DDE (diclorodifenildicloroetileno) e metilmercúrio foram encontrados em peixes e aves aquáticas (BEEK, 2000).

A acumulação seletiva de metais pesados por micro-organismos é determinada pela competição inter iônica, e a quantidade total de íons adsorvidos por diferentes células microbianas difere muito de espécie para espécie (NAKAJIMA \& SAKAGUCHI, 1986).

A bioacumulação tem sido tradicionalmente melhor estudada por microbiologistas devido à sua importância toxicológica, e tem sido menos utilizada em processos de eventual recuperação de metais porque a bioacumulação requer a utilização de células metabolicamente ativas (VOLESKY, 1990).

O uso de biomassa microbiana com a finalidade de detoxificação de efluentes industriais para proteção ambiental e recuperação da metais valiosos 
por meio da biossorção disponibiliza uma tecnologia alternativa potencial (GADD, 2000 e LLOYD, 2003).

Nos rejeitos radioativos, a microbiologia começou com a constatação de que os micróbios podem existir em formações relevantes para os repositórios de rejeitos e que os efeitos da atividade microbiana poderiam ter influências profundas na contenção dos rejeitos (WEST et al., 2002 apud MERROUN e SALENSKA-POBELL, 2008).

Os micro-organismos podem potencialmente afetar a migração de radionuclídeos por vários processos, sendo capazes de precipitar metais e radionuclídeos com carbonatos e hidróxidos por alcalinização localizada na superfície celular (MERROUN e SALENSKA-POBELL, 2008).

No mecanismo de bioacumulação muitos micro-organismos efetivamente ligam-se a íons metálicos perigosos e potencialmente tóxicos. Dois principais mecanismos de remoção de íons metálicos são reconhecidos. O primeiro mecanismo envolve a ligação que ocorre na superfície da membrana celular sem gasto de energia. No segundo, os íons metálicos podem entrar na célula através da membrana e participar das vias bioquímicas. A superfície de ligação de íons metálicos é muito importante e geralmente representa a principal fonte de ligação de íons metálicos (GADD et al., 1985 apud AL-SARAJ et al., 1999). Isto é possível devido à abundância de sítios de ligação como membranas compostas principalmente de proteínas, lipídios e polissacarídeos, que são ricas em sítios de ligação de íons metálicos como carboxilatos, aminas, amidas, hidroxilas, fosfatos, tióis bem como outros (AL-SARAJ et al., 1999; SAR et al., 2004; KADUKOVÁ, 2005; VELÁSQUEZ e DUSSAN, 2009; CHOJNACKA, 2010).

A parede celular é considerada um complexo trocador de íons, assim como uma resina. A capacidade de troca iônica varia de acordo com a da presença de grupos funcionais e da estrutura espacial da própria parede celular. Dentre os principais grupos funcionais responsáveis por mecanismos de captação de metais, pode-se citar a carboxila, o grupo amino, sulfato e fosfato, que são responsáveis pela captação de cátions metálicos, tanto pela atração eletrostática quanto pela formação de ligações dipolo-dipolo. Portanto, essa interação pode ser particularmente pronunciada no caso de íons metálicos devido às características aniônicas da parede celular (APARÍCIO, 2000; VEGLIÓ et al., 1997). 
Os mecanismos de transporte envolvidos na acumulação de metais pesados são pouco conhecidos. Uma das suposições seria a de que os metais pesados podem ser captados pelos sistemas de transporte de metais essenciais para o desenvolvimento microbiano (GADD, 1988). Uma vez dentro da célula, os íons metálicos podem se localizar em organelas, ou podem estar ligados a proteínas, deslocando os íons de suas posições adequadas, prejudicando as funções metabólicas (GADD, 1992).

\subsection{Biossorção vs Bioacumulação}

Dos diferentes métodos biológicos, a bioacumulação e a biossorção têm demonstrado possuir bom potencial para substituir métodos convencionais para absorção de metais/tintas (VOLESKY e HOLAN, 1995).

É possível encontrar contradições na literatura quanto ao uso dos termos biossorção e bioacumulação. Entretanto, a bioacumulação pode ser entendida como um processo em que se utiliza biomassa viva, enquanto na biossorção, utiliza-se biomassa inativa. A bioacumulação pode ser definida como absorção de substâncias tóxicas por células vivas. As substâncias tóxicas podem ser transportadas dentro das células, através da membrana celular ou do ciclo metabólico das células (MALIK, 2004). Ao contrário, a biossorção pode ser definida como absorção passiva de substâncias tóxicas por materiais biológicos inativos, ou ainda, por materiais derivados de fontes biológicas. A biossorção se deve a numerosos processos independentes do metabolismo que essencialmente ocorrem na parede celular, onde os mecanismos responsáveis pela captação dos poluentes serão diferentes, de acordo com 0 tipo de biomassa (VIJAYARAGHAVAN e YUN, 2008). A tabela 1 apresenta as principais diferenças entre a biossorção e bioacumulação. 
Tabela 1. Comparação entre biossorção e bioacumulação.

\begin{tabular}{|c|c|c|}
\hline Fatores & Biossorção & Bioacumulação \\
\hline Custo & $\begin{array}{l}\text { Normalmente baixo. Muitos } \\
\text { biossorventes são biomassas } \\
\text { resultantes de resíduos } \\
\text { industriais ou de agricultura. } \\
\text { Custo envolve o transporte ou } \\
\text { alterações de processos. }\end{array}$ & $\begin{array}{l}\text { Geralmente alto. O processo } \\
\text { envolve células vivas e o } \\
\text { custo da manutenção das } \\
\text { células vivas. }\end{array}$ \\
\hline $\mathrm{pH}$ & $\begin{array}{l}\mathrm{O} \text { pH influencia fortemente a } \\
\text { capacidade de absorção da } \\
\text { biomassa. }\end{array}$ & $\begin{array}{l}\text { As células vivas em si são } \\
\text { fortemente afetadas sob } \\
\text { condições extremas de pH. }\end{array}$ \\
\hline Temperatura & $\begin{array}{l}\text { Possível melhora da absorção } \\
\text { com o aumento da } \\
\text { temperatura. }\end{array}$ & $\begin{array}{l}\text { A temperatura afeta } \\
\text { severamente o processo. }\end{array}$ \\
\hline $\begin{array}{l}\text { Manutenção/ } \\
\text { armazenamento }\end{array}$ & Fácil de armazenar e usar. & $\begin{array}{l}\text { Energia metabólica externa é } \\
\text { necessária para a } \\
\text { manutenção da cultura. }\end{array}$ \\
\hline Seletividade & $\begin{array}{l}\text { Pobres, a seletividade pode } \\
\text { ser melhorada pela ativação } \\
\text { da biomassa. }\end{array}$ & Melhor que na biossorção. \\
\hline Versatilidade & $\begin{array}{l}\text { Razoavelmente bom. Os sítios } \\
\text { de ligação podem acomodar } \\
\text { uma variedade de íons. }\end{array}$ & $\begin{array}{l}\text { Não muito flexível. Propenso } \\
\text { a ser afetado pelas altas } \\
\text { concentrações } \\
\text { metais/sais. }\end{array}$ \\
\hline $\begin{array}{ll}\text { Grau } & \text { de } \\
\text { absorção. } & \end{array}$ & $\begin{array}{l}\text { Muito alto. Algumas } \\
\text { biomassas absorvem uma } \\
\text { quantidade de substância } \\
\text { tóxica quase tão elevado } \\
\text { como o seu peso seco. }\end{array}$ & $\begin{array}{l}\text { São sensíveis a altas } \\
\text { concentrações } \\
\text { substâncias tóxicas e a } \\
\text { remoção é geralmente baixa. }\end{array}$ \\
\hline
\end{tabular}




\begin{tabular}{|c|c|c|}
\hline Fatores & Biossorção & Bioacumulação \\
\hline $\begin{array}{l}\text { Taxa } \\
\text { absorção }\end{array}$ & Geralmente rápida. & $\begin{array}{l}\text { Geralmente mais lenta que a } \\
\text { biossorção, pois a } \\
\text { acumulação intracelular é } \\
\text { morosa. }\end{array}$ \\
\hline $\begin{array}{l}\text { Regeneração e } \\
\text { reuso. }\end{array}$ & $\begin{array}{l}\text { Alta possibilidade de } \\
\text { regeneração do biossorvente, } \\
\text { com possível reuso ao longo } \\
\text { de vários ciclos. }\end{array}$ & $\begin{array}{l}\text { Como os metais tóxicos são } \\
\text { acumuladas intracelularmen- } \\
\text { te, as chances são muito } \\
\text { limitadas. }\end{array}$ \\
\hline $\begin{array}{l}\text { Recuperação da } \\
\text { substância } \\
\text { tóxica. }\end{array}$ & $\begin{array}{l}\text { Em muitos casos soluções } \\
\text { ácidas ou alcalinas tornam-se } \\
\text { meios eficientes para a } \\
\text { recuperação das substâncias } \\
\text { tóxicas. }\end{array}$ & $\begin{array}{l}\text { A biomassa não poderá ser } \\
\text { utilizada para o próximo ciclo. }\end{array}$ \\
\hline Imobilização & $\begin{array}{l}\text { É possível utilizar a biomassa } \\
\text { em estruturas sólidas. }\end{array}$ & $\begin{array}{l}\text { Não é possível imobilizar a } \\
\text { biomassa viva. }\end{array}$ \\
\hline Reversibilidade & Possível. & Parcialmente reversível. \\
\hline Velocidade & Rápida. & Lenta. \\
\hline $\begin{array}{l}\text { Número } \\
\text { estágios. }\end{array}$ & Estágio único (só biossorção) & $\begin{array}{l}\text { Estágio duplo (biossorção + } \\
\text { bioacumulação) }\end{array}$ \\
\hline $\begin{array}{l}\text { Ligação } \\
\text { metal }\end{array}$ & $\begin{array}{l}\text { Os metais se ligam na } \\
\text { superfície celular. }\end{array}$ & $\begin{array}{l}\text { Os metais se ligam na } \\
\text { superfície celular e em seu } \\
\text { interior. }\end{array}$ \\
\hline
\end{tabular}

Adaptação de (VIJAYARAGHAVAN e YUN, 2008 ; CHOJNACKA, 2010)

\subsection{Biossorventes}

Em geral todos os tipos de biomateriais, tais como bactérias, fungos, algas, resíduos industriais e da agricultura e outros polissacarídeos têm mostrado boa capacidade de biossorção para todos os tipos de íons metálicos (VIJAYARAGHAVAN e YUN, 2008). 
O estudo das interações entre os micro-organismos e os metais pesados tem despertado grande interesse da comunidade científica. Dentre os fungos, as leveduras são as mais exploradas cientificamente, pelo fato de serem organismos eucariontes de fácil manipulação, sendo consideradas um excelente modelo para o estudo de diversos problemas de relevância dentro da biologia (BROCK et al., 1994). A levedura Saccharomyces cerevisiae tem sido bastante utilizada para biossorção de metais presentes de soluções aquosas (LIU et al., 2002-b, BRADY e DUNCAN; 1984; BAYAN et al., 2001; ADAMIS et al., 2003; EIDE, 1998; GOMES et al., 2006; KEDARI et al., 2001; MACHADO et al., 2008; VOLESKY, 1994; VOLESKY e MAY-PHILLIPS, 1995).

A técnica de imobilização é um dos elementos chave para a aplicação prática da biossorção, especialmente por biomassa inativada. Vários tipos de materiais de imobilização para Saccharomyces cerevisiae têm sido estudados (VEGLIO e BEOLCHINI, 1997), como por exemplo, géis de alginato de cálcio (MEENA e RAJA, 2006; BUSTARD e MCHALE, 1997; WANG e CHEN, 2006; LIU et al., 2003).

O alginato, biopolímero disponível comercialmente, há muito usado na indústria para diversas finalidades e, mais recentemente na imobilização de células (MARTINSEN et al., 1991), tem sido também estudado como biossorvente na remoção de íons de metais e radionuclídeos (GOMES et al., 2006; BANERJEE e NAYAK, 2007; IBÁÑEZ e UMETSU, 2002; MIMURA et al., 2001; MIMURA et al., 2002; PAPAGEORGIOU et al., 2006; GOK e AYTAS, 2009).

O emprego de biomassa bacteriana para remoção de metais no tratamento de efluentes é uma perspectiva sugerida por muitos pesquisadores que estudam a interação das bactérias com os metais. A relevância dessas interações nos ciclos geoquímicos é amplamente reconhecida, pois as bactérias podem afetar muito a mobilidade dos metais por diversos mecanismos como solubilizações e precipitações (EHRLICH, 1990 apud VECCHIO, 1998).

\subsubsection{Saccharomyces cerevisiae}

Saccharomyces cerevisiae são fungos unicelulares eucarióticos com capacidade de biossorção conferida pelos componentes celulares (BREIEROVÁ 
et al. 2002) e, segundo Brady e Duncan (1984), pela parede celular, o que conferiria um sítio adicional em relação a outros organismos desprovidos de parede celular.

A parede celular de Saccharomyces cerevisiae é uma estrutura elástica que proporciona proteção osmótica e física e determina a forma da célula. A camada interna da parede é, em grande parte, responsável pela resistência mecânica da parede e também fornece os locais de ligação para as proteínas que formam a camada exterior da parede. A camada externa de proteína também limita a permeabilidade da parede celular, protegendo a membrana plasmática de um ataque por enzimas de membrana externa e compostos perturbadores. As principais características da organização molecular da parede celular de levedura são conhecidas. É importante salientar que a composição e organização molecular da parede celular podem variar consideravelmente. Por exemplo, a incorporação de muitas proteínas da parede celular é temporal e especialmente controlada e depende fortemente das condições ambientais. Do mesmo modo, a formação de proteínas específicas na parede celular de polissacarídeos complexos é fortemente afetada por condições externas (KLIS et al., 2002).

A Saccharomyces cerevisiae é facilmente cultivada em larga escala, esta levedura cresce sem técnicas sofisticadas e o meio de cultura não é de alto custo (KAPOOR e VIRARAGHAVAN, 1995).

A biomassa de Saccharomyces cerevisiae pode ser obtida em indústrias de bebidas e alimentos. É um subproduto da indústria de fermentação e, portanto, pode ser obtida facilmente se comparada com outras biomassas microbianas. Micro-organismos utilizados na indústria enzimática e na indústria farmacêutica, estão geralmente envolvidos em seus segredos de produção industrial, o que faz com que as indústrias relutem em disponibilizar os resíduos de biomassa microbiana da produção. (WANG e CHEN, 2006)

Saccharomyces cerevisiae, é considerado o modelo preferido para estudos de estresse em células eucarióticas. É um organismo útil para a identificação de mecanismos moleculares que controlam a sensibilidade a metais. A utilização de organismos inferiores, como as células de levedura, como sistemas modelo é particularmente atraente, devido à facilidade de manipulação genética, disponibilidade da sequência do genoma completo da Saccharomyces cerevisiae 
e a aparente conservação dos mecanismos moleculares entre leveduras e células humanas (ADAMIS et al., 2003).

Entre os diferentes tipos de biomassa disponível, as células de levedura Saccharomyces cerevisiae constituem boa alternativa de tratamento rejeitos líquidos, principalmente porque é geralmente reconhecida como um microorganismo seguro e pode ser usado sem preocupação, tem capacidade para acumular uma vasta gama de metais pesados em uma variedade de condições externas (VOLESKY e MAY-PHILLIPS, 1995; WANG e CHEN, 2006). Adamis et al. (2003) estudaram a remoção de Cd em solução aquosa com concentração inicial de $10 \mu \mathrm{g} / \mathrm{mL}$ e obtiveram 97\% de remoção em 24 horas de contato.

A levedura Saccharomyces cerevisiae é um organismo ideal para decifrar o mecanismo e regulação do transporte de íons metálicos. Estudos recentes de levedura mostraram que a acumulação de qualquer íon metálico único é mediada por dois ou mais substratos de sistemas de transporte específicos (EIDE, 1998).

\subsubsection{Alginato de sódio}

O alginato de sódio é um copolímero linear obtido a partir da extração do ácido algínico encontrado em algas marrons e algumas bactérias, utilizando-se álcali diluído (LIMA, 2006).

Os alginatos, sais de copolímeros não ramificados de ligações $1 \rightarrow 4$ de ácido $\beta$-D- manurônico e ácido $\alpha$-L-gulurônico, (figura 2) são polissacarídeos de origem principalmente algal (constituindo até cerca de $40 \%$ do peso seco de algas marrons)(ÖNAL et al., 2007, LIMA, 2006; MIMURA et al., 2001). Entre suas características principais está a de formar géis termicamente irreversíveis com a maioria dos cátions bivalentes, com exceção do magnésio (TEIXEIRA e ARAÚJO, 1996; NAYAK e LAHIRI, 2005). 


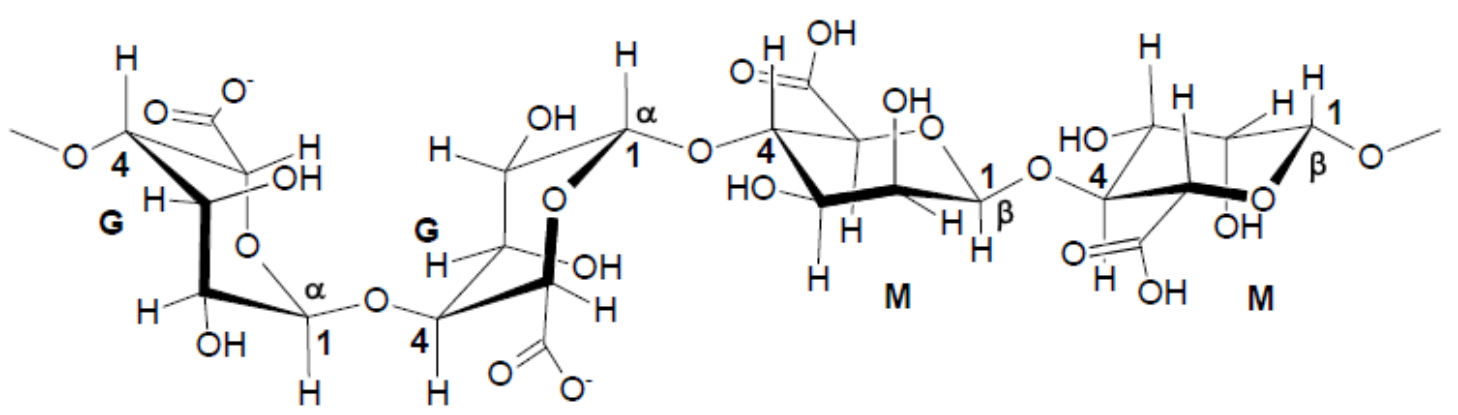

Figura 2. Estrutura e disposição alternadas dos blocos de $M$ e $G$ ao longo da cadeia de algínico. Fonte: LIMA, 2006.

Quando uma solução de alginato de sódio é gotejada numa solução contendo íons metálicos bivalentes, são formadas esferas de alginato de cátions insolúveis em água. O cálcio é o cátion mais utilizado na preparação de esferas para uma ampla aplicação: principalmente para imobilizar células que são utilizadas em biocatalisadores ou para imobilizar biomoléculas como pesticidas, drogas, e outras (VELINGS e MESTDAGH, 1995; IBAÑEZ e UMETSU, 2004). Após a formação das esferas de alginato com íons de cálcio, a estrutura particular deste biopolímero deixa livre grupos carboxílicos que reagem com os íons metálicos (IBÁÑEZ e UMETSU, 2002).

Os íons metálicos interagem com as regiões dos blocos $\mathrm{G}$, assim, os íons de cálcio ficam ligados à cadeia de polissacarídeo, como se fosse uma caixa de ovos, o chamado modelo "egg-box". (Figura 3)

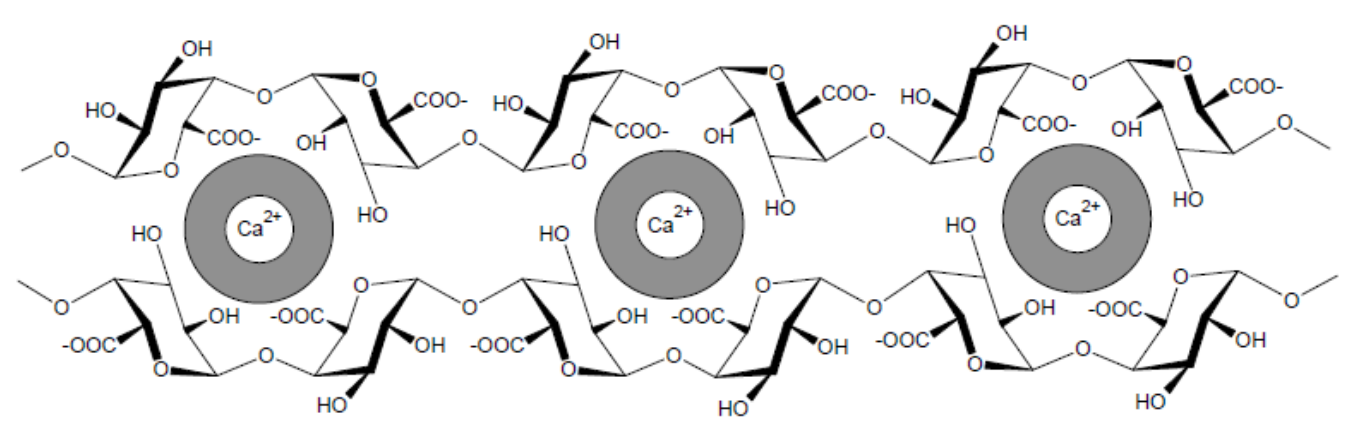

Figura 3. Modelo "egg-box" proposto para o alginato de sódio. Fonte: LIMA, 2006. 
O fator que controla a formação de um gel é a quantidade de blocos $G$ presentes no alginato de sódio e também a concentração de íons de cálcio adicionados à solução. Assim, existe uma classificação dos alginatos ricos em blocos $\mathrm{G}$ ou M, dependendo da espécie de alga da qual foi obtido (LIMA, 2006).

$O$ alginato apresenta vantagens sobre outros materiais, como biodegradabilidade, hidrofilicidade, presença de grupos carboxílicos e origem natural (KAÇAR et al., 2002; NAYAK e LAHINI, 2005; GOK e AYTAS, 2009).

A presença de grupos carboxílicos na sua estrutura favorece a ligação com íons metálicos e por este motivo, os alginatos em forma de esferas têm sido estudados para a remoção de metais presentes em soluções aquosas em baixas concentrações (MIMURA et al., 2001; MIMURA et al., 2002; IBAÑEZ e UMETSU, 2004; NAYAK e LAHIRI, 2005; GOK e AYTAS, 2009).

$O$ alginato pode ser utilizado como adsorvente para a remoção de metais e também de radionuclídeos presentes em rejeitos líquidos (MIMURA et al., $2001 \mathrm{e}$ MIMURA e AKIBA, 2002; VEGLIÓ et al., 2002; ÖNAL et al., 2007; PAPAGEORGIOU et al., 2008).

Banerjee et al. (2007), estudaram a capacidade da biossorção de $\mathrm{Cu}, \mathrm{Zn}$, $\mathrm{Ga}, \mathrm{Ge}$ e As por micro esferas de alginato de cálcio e constataram que a remoção é melhor em $\mathrm{pH} 4$ para todos os metais estudados, exceto para o $\mathrm{Ge}$, que é removido até $100 \%$ em pH 7 em 6 horas de contato. Göksungur et al. (2003) estudaram a biossorção do $\mathrm{Cu}^{2+}$ em solução aquosa de concentração inicial de $10-50 \mathrm{mg} / \mathrm{mL}$ com pH 4 e obtiveram $100 \%$ de remoção para as maiores concentrações entre 30 e 60 minutos.

$O$ alginato de cálcio tem sido utilizado como matriz de imobilização de células microbianas através da técnica de aprisionamento (KAÇAR et al., 2002). A imobilização serve para melhorar as características físicas da biomassa para uso em reatores, permite a reutilização das substâncias (VOLESKY, 1990) e facilita o processo de separação das células do rejeito líquido (DAS et al., 2002).

Existem quatro formas de imobilização (figura 4), imobilização na superfície de um carreador sólido por ligação covalente, aprisionamento em matriz porosa, agregação celular obtida por floculação natural e retenção celular entre membranas micro porosas (KOURKOUTAS et al., 2004). 


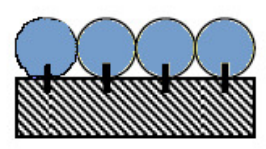

a) Imobilização na superfície de um carreador sólido por ligação covalente.

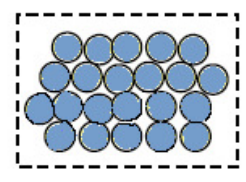

c) Agregação celular obtida por floculação natural

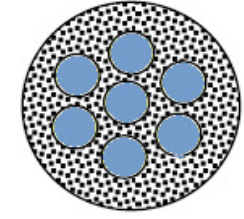

b) Aprisionamento em matriz porosa.

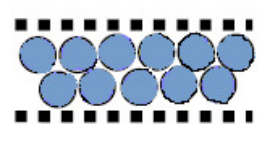

d) Retenção celular entre membranas microporosas.

Figura 4. Métodos básicos de imobilização celular. Adaptado de Kourkoutas et al., 2004.

O alginato de cálcio na forma de esferas (figura 5) é utilizado para encapsular células a serem utilizadas como biocatalisadores (OLIVEIRA, 2006).

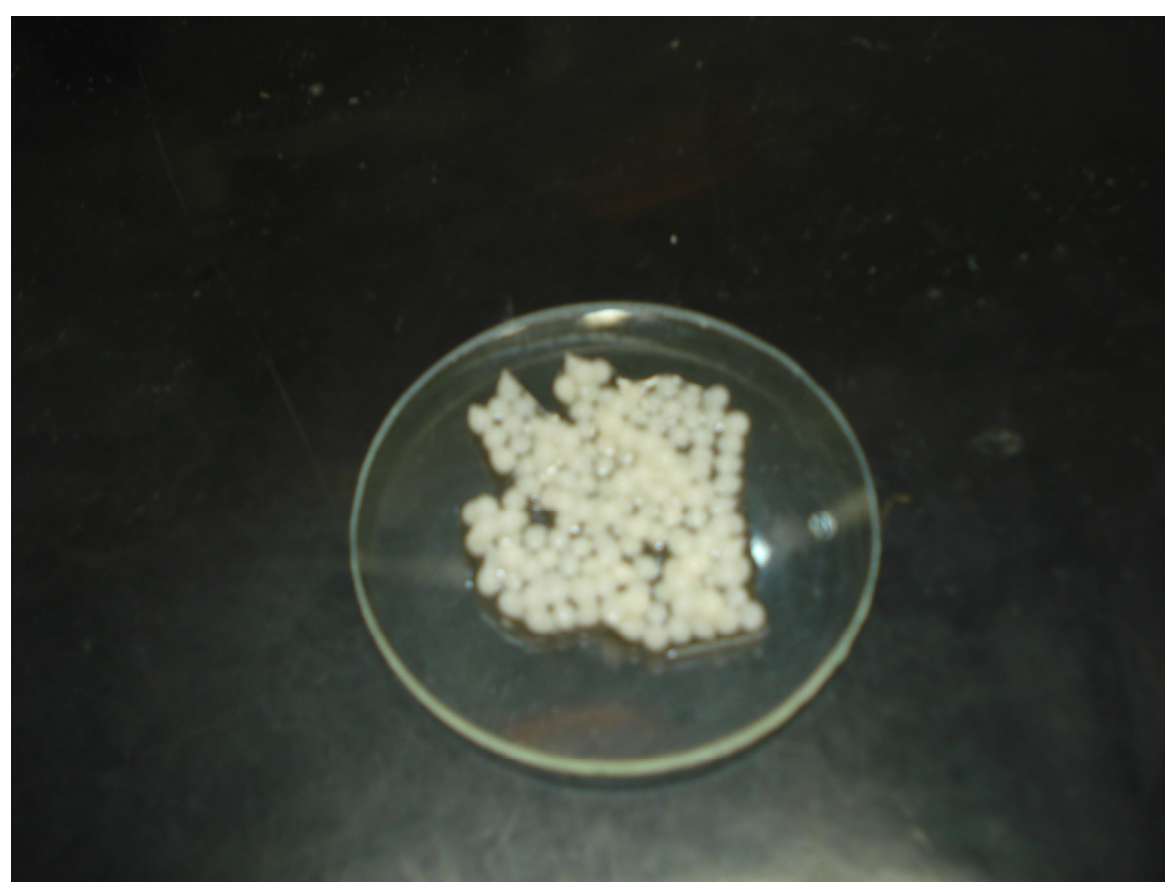

Figura 5 - Micro esferas de alginato de cálcio com células de Saccharomyces cerevisiae inativadas. 


\subsubsection{Bactérias}

As bactérias são seres unicelulares procariontes, com grande variedade de tipos morfológicos e fisiológicos. Algumas bactérias podem ser diferenciadas pelo uso do método de coloração Gram (figura 6). A linhagem Gram-positiva contém espécies que apresentam filogenia e estrutura de parede celular em comum (MADIGAN et a, 2008).

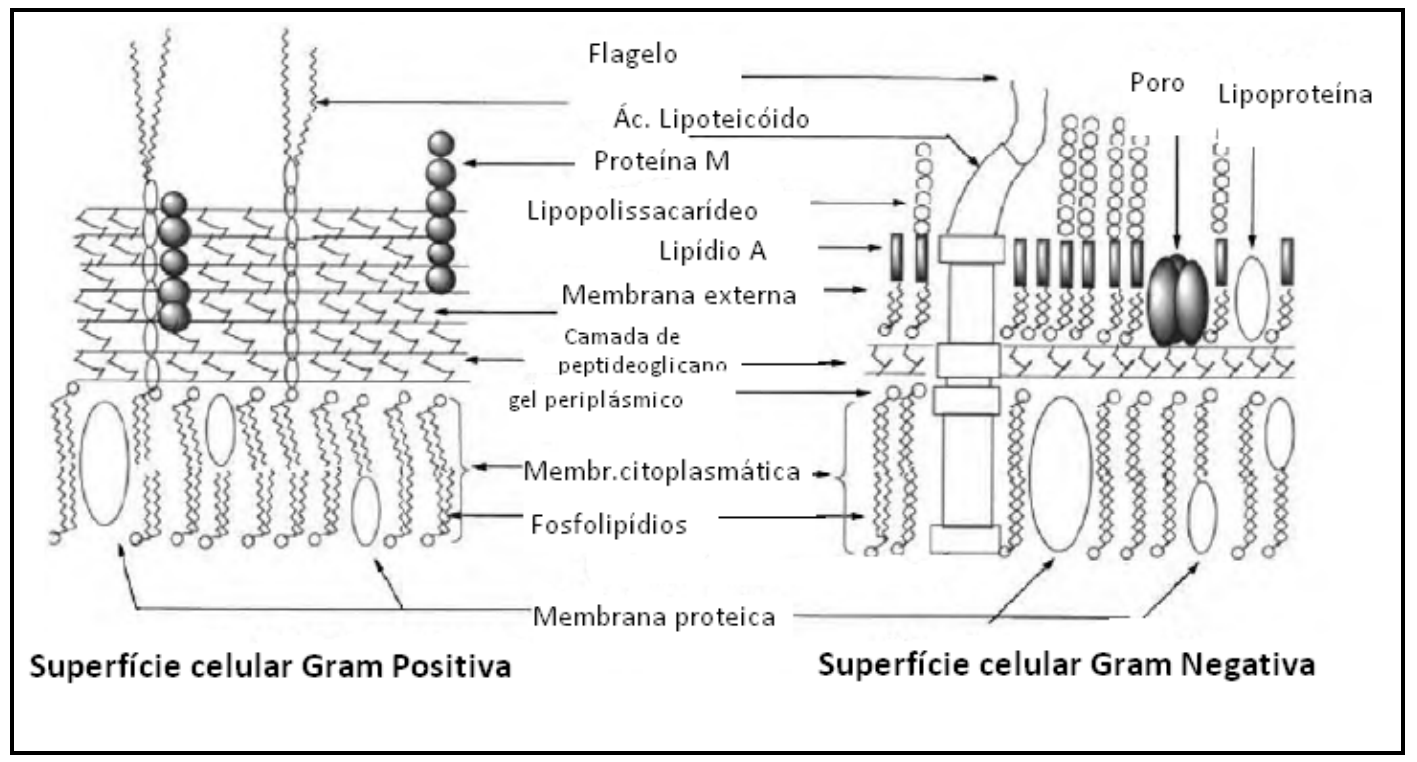

Figura 6: Composição da superfície celular de bactérias Gram-positiva e Gram-negativa. Fonte: (WANG, 2009).

A parede celular das bactérias fornece a integridade estrutural da célula, mas distingue-se de todos os outros organismos, devido à presença de peptideoglicano (poli-N-acetilglicosamina e ácido $\mathrm{N}$-acetilmurâmico), que está localizado imediatamente fora da membrana citoplasmática. O peptideoglicano é responsável pela rigidez da parede celular bacteriana e determina a forma da célula. Também é relativamente poroso e considerado como uma barreira impermeável a substratos de pequeno porte. As paredes celulares de todas as bactérias não são idênticas. Na verdade, a composição da parede celular é um dos fatores mais importantes na análise e diferenciação de espécies bacterianas. Assim, dois tipos gerais de bactérias existem: as Gram-positivas que são 
compostas por uma camada espessa de peptideoglicano (cerca de 90\%) e, as Gram-negativas, que possuem uma camada de peptideoglicano mais fina (entre 10 e 20\%), figura 6, além disso, a parede celular contém uma membrana externa adicional formada de fosfolipídeos e lipopolissacarídeos (VIJAYARAGHAVAN e YUN, 2008).

\subsubsection{Bacillus subtilis}

A Bacillus subtilis (figura 7) é uma bactéria Gram-positiva, habitante natural do solo, produtora de antibióticos, enzimas e fito-hormônios que proporcionam benefícios para as plantas. Essa espécie microbiana é também descrita como rizobactéria promotora de crescimento de plantas (RPCP) (ARAÚJO, 2008).

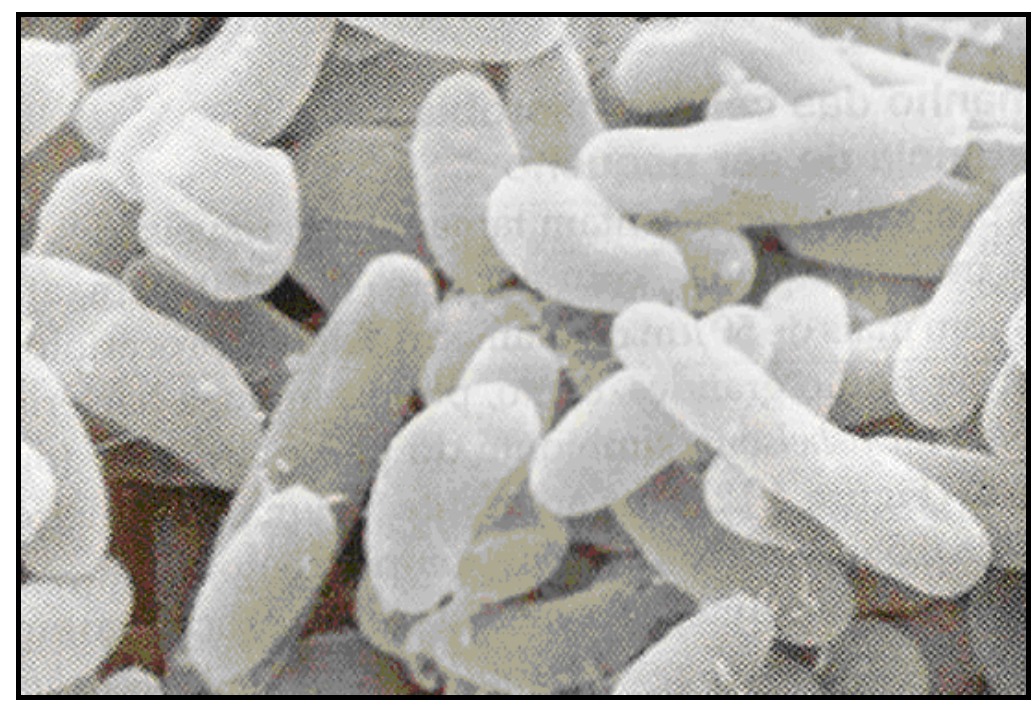

Figura 7. Bacillus subtilis Fonte: MADIGAN, 2008.

Nas últimas décadas, foram encontradas diversas aplicações de Bacillus subtilis, incluindo produção industrial de proteases, preparação de alimentos por fermentação alcalina e como produto probiótico para prevenção de infecções entéricas tanto em humanos quanto em animais. O conhecimento da fisiologia e da genética do Bacillus subtilis, associado ao desenvolvimento de ferramentas genéticas tem trazido maior interesse para se fazer modificações genéticas com objetivos diversos. Seus esporos podem permanecer dormentes e viáveis por longos períodos de tempo, talvez por milhões de anos (PACCEZ et al., 2007). 
A parede da bactéria Bacillus subtilis, como as de outras bactérias Grampositivas é composta principalmente uma espessa camada de peptideoglicano que apresenta grupos carboxílicos de ácido teicóicos associados (figura 8) (COSTA e DUTA, 2001).

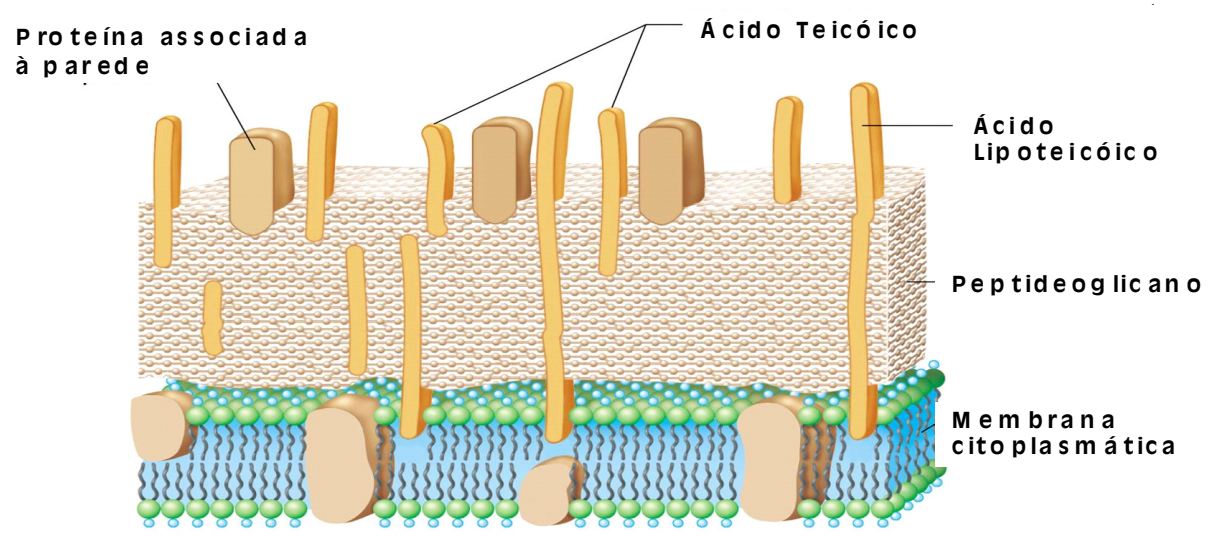

Figura 8. Diagrama da parede celular da bactéria Bacillus subtilis. Fonte: MADIGAN, 2008.

A elucidação dos sítios ativos de ligação da parede da Bacillus subtilis revelou a contribuição dos grupos carboxila, amina, hidroxila e fosforila. O grupo amina é positivamente carregado e deve estar envolvido à ligação com ânions, tais como silicatos, os demais grupos são negativamente carregados e, portanto, devem estar relacionados a ligação com cátions (HUANG, 2002).

Existem diversos estudos da aplicação de Bacillus subtilis na remoção de metais como cobre, prata zinco e cádmio (COSTA e DUTA, 2001), magnésio, cobre, ferro, sódio, potássio, manganês, zinco, cálcio, ouro, níquel, mercúrio, estrôncio, chumbo, prata, cobalto, lítio, bário e alumínio (BEVERIDGE e MURRAY, 1976). 


\subsubsection{Cupriavidus metallidurans}

Cupriavidus metallidurans (figura 9) é uma $\beta$-proteobactéria, Gramnegativa, não patogênica, capaz de crescer em elevadas concentrações de, pelo menos, treze diferentes íons de metais pesados (MONCHY et al., 2006; MERGEAY et al., 2003 ). Cupriavidus (ex. Ralstonia) metallidurans CH34 é uma bactéria hidrogenotróficas facultativa resistente a metais, bactéria isolada do lodo de um tanque de decantação de zinco na Bélgica, que foi contaminado com altas concentrações de vários metais pesados (MONCHY et al., 2007).

Esta bactéria tem ganhado interesse crescente como um organismo modelo para detoxificação de metais pesados e para fins biotecnológicos. A resistência da bactéria aos cátions de metais de transição é predominantemente baseada na resistência devida aos genes para RND (resistência, a nodulação e a família de proteínas de células de divisão) proteínas (ROZYCKI e NIES, 2009).

Estão relatadas na literatura resistências da bactéria Cupriavidus metallidurans $\mathrm{CH} 34$ a arsenito (AsO4-3), bismuto $\left(\mathrm{Bi}^{+3}\right)$, gadolínio $\left(\mathrm{Gd}^{+3}\right)$, ouro $(\mathrm{Au}+)$, prata $(\mathrm{Ag}+)$, selenito $(\mathrm{SeO}-2)$, tálio $(\mathrm{Tl}+)$ e urânio $\left(\mathrm{U}^{+2}\right)$, entretanto, a maioria dos mecanismos ainda não está totalmente esclarecida (BIONDO, 2008).

$\mathrm{Na}$ bactéria Cupriavidus metallidurans foram identificados os genes envolvidos na resistência aos metais pesados Co (II), $\mathrm{Cr}$ (VI), $\mathrm{Hg}$ (II) e Ni (II) que estão concentradas em uma região de $34 \mathrm{~kb}$ no plasmídeo pMOL28, e os genes envolvidos na resistência a $\mathrm{Ag}$ (I), Cd (II), Co (II), Cu (II), Hg (II), Pb (II) e Zn (II) ocorrem em uma região de $132 \mathrm{~kb}$ do plasmídeo pMOL30. Foram identificadas três supostas ilhas genômicas operons contendo resistência a metais, ladeados por elementos genéticos móveis, um em pMOL28 e dois no pMOL30 (MONCH, 2007). 


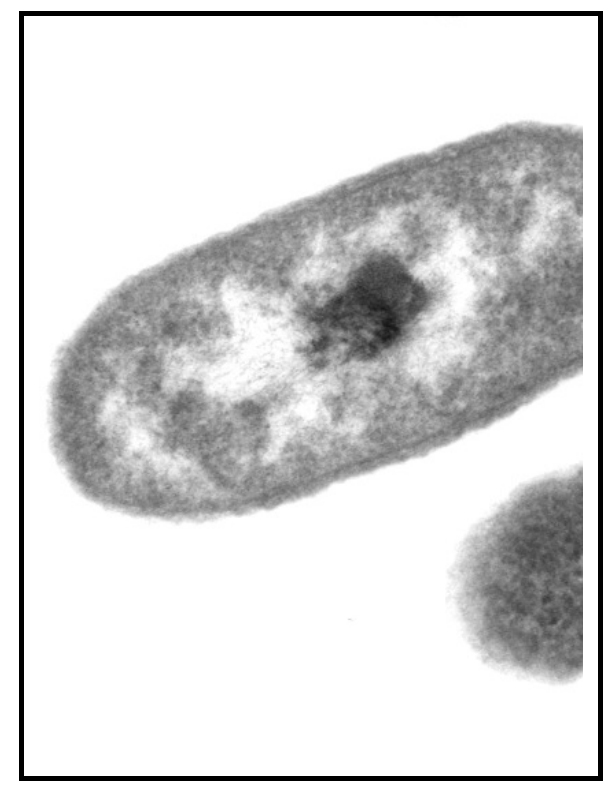

Figura 9 - Cupriavidus metallidurans. Fonte: BIONDO, 2008.

\subsubsection{Ochrobactrum anthropi}

A bactéria Ochrobactrum anthropi (figura 10) é um bacilo Gram-negativo, classificado como Achromobacter e atualmente reconhecido como pertencente ao gênero Ochrobactrum. Este organismo tem distribuição ambiental ampla, sendo encontrado na água, no solo, em plantas, entre outros ambientes. Embora seja considerado um agente patogênico oportunista em pacientes imunocomprometidos, é crescente o reconhecimento de que seja um agente causal de hospedeiros saudáveis (OZDEMIR et al., 2006).

Cepas Ochrobactrum apresentam interesse particular para biorremediação. São capazes de degradar pesticidas organofosforados, solventes tóxicos, resíduos de petróleo (SELEEM et al., 2006) e, também são capazes de remover cromo, cádmio, cobre e outros metais tóxicos do ambiente (OZDEMIR, et al., 2003, CHENG et al., 2010).

Li et al. (2008) estudaram a remoção de $\mathrm{Cr}(\mathrm{IV})$ por Ochrobactrum anthropi viáveis e obtiveram remoção de $95 \%$ do $\operatorname{Cr}(\mathrm{IV})$ em solução com concentração inicial de $400 \mathrm{mg} / \mathrm{L}^{-1}$. 
Ochrobactrum anthropi é uma das bactérias isoladas por Ferreira et al. (2009), de amostras de chorume obtido de lisímetros contendo fonte de ${ }^{241} \mathrm{Am}$ e, portanto, resistente ao ${ }^{241} \mathrm{Am}$. Por este motivo foi uma das bactérias escolhidas para o presente estudo.

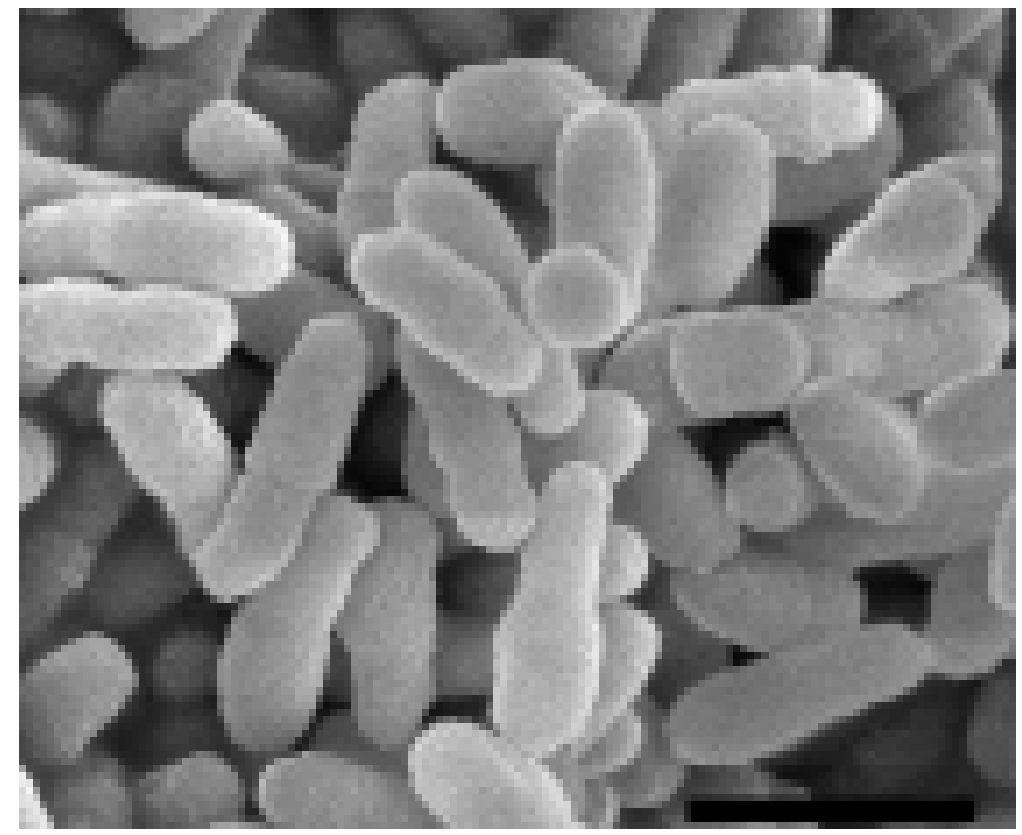

Figura 10. Ochrobactrum anthropi. Fonte: LI, 2008.

\subsection{Biorremoção de Amerício-241}

A literatura apresenta diversos estudos de remoção de ${ }^{241} \mathrm{Am}$ em solução aquosa, utilizando-se materiais biológicos, tanino (MATSUMURA, 1998), alginato de cálcio (MIMURA, 2001; MIMURA et al., 2002), Saccharomyces cerevisiae (DAS, 2002; KEDARI, 2001 e LIU et a.l, 2002-b), Rhizopus arrihizus (LIAO et al., 2004; LIU et al, 2002-a; DHAMl et al., 2004) e Candida sp (LOU, 2003).

Matsumura et al. (1998) estudaram a aplicabilidade do tanino insolúvel para o tratamento de rejeitos contendo amerício e concluíram que é aplicável a utilização do tanino para este fim, embora a cinética de adsorção encontrada tenha sido lenta. A capacidade de adsorção de ${ }^{241} \mathrm{Am}$ por tanino foi de $7 \times 10^{-3}$ $\mathrm{mmol} / \mathrm{g}$.

A utilização da Saccharomyces cerevisiae imobilizada é descrita na literatura como método prático de remoção de radionuclídeos em soluções. Das et al. (2002), realizaram o estudo de biossorção de ${ }^{241} \mathrm{Am}$ com a levedura imobilizada em agentes floculantes, e verificaram, entre outros parâmetros, os 
efeitos do $\mathrm{pH}$, da temperatura e do tempo de contato. Observou-se que a biossorção do ${ }^{239} \mathrm{Pu},{ }^{241} \mathrm{Am},{ }^{144} \mathrm{Ce},{ }^{137} \mathrm{Cs},{ }^{103,106} \mathrm{Ru}$ e ${ }^{90} \mathrm{Sr}$, em pH de 1-2 chegou em $95 \%$ independente do ânion, após 60 minutos e, no caso do ${ }^{233} \mathrm{U}$, em 100 minutos de contato.

Nos estudos de biossorção de ${ }^{241} \mathrm{Am}$ em solução aquosa por fungos Liu et al. (2002-a) constataram a remoção por Rhizopus arrihizus livres de mais de 99\% do amerício presente em soluções de concentrações entre 5,6 e $111 \mathrm{MBq} / \mathrm{l}$ em 1 hora de contato em pH entre 1 e 3 com temperatura de 10 a $45^{\circ} \mathrm{C}$.

Dhami et al. (2004), também estudaram a utilização de Rhizopus arrihizus livres na biossorção de ${ }^{241} \mathrm{Am}$ em solução aquosa e concluíram que esta biomassa é um excelente e econômico biomaterial para a biossorção de ${ }^{241} \mathrm{Am}$ em meio ácido $\left(\mathrm{pH}\right.$ 2) com 3 horas de contato e concentração de $5676 \mathrm{~Bq}^{241} \mathrm{Am}$ $/ \mathrm{mL}$ em $\mathrm{HNO}_{3}$.

Liao et al. (2004) utilizaram Rhizopus arrihizus imobilizado em alginato de cálcio para remover ${ }^{241} \mathrm{Am}$ de solução aquosa e estudaram os seguintes parâmetros: tempo de contato, $\mathrm{pH}$ e temperatura. Em 2 horas de contato, mais de $97 \%$ do ${ }^{241} \mathrm{Am}$ foi removido da solução com atividade inicial de $1,08 \mathrm{MBq} / \mathrm{lcom} \mathrm{pH}$ entre 1 e 7 e, a temperatura não teve influência no processo.

Candida $s p$ foi utilizada como biossorvente em estudos de biossorção de ${ }^{241} \mathrm{Am}$ em soluções de concentrações que variavam de 5,6 a $111 \mathrm{MBq} / \mathrm{l}$. Além da concentração inicial, outros parâmetros foram estudados, como $\mathrm{pH}$, tempo de contato e temperatura. Estes estudos demonstraram que Candida $s p$ removeu $98 \%$ do amerício presente nas soluções com pH 2 em 4 horas de contato, sendo que a temperatura não influenciou o processo (LOU, 2003).

Takenaka et al. (2007) utilizaram Pseudomonas fluorescens como biossorvente e obtiveram remoção de $100 \%$ de Am-241 em solução de concentração inicial igual a $10^{-10} \mathrm{M}$ em pH 2 e 3. Luk'yanova et al. (2007) estudaram a sorção de radionuclídeos por micro-organismos isolados de um repositório de rejeitos líquidos de baixo nível e constataram que bactérias do gênero Pseudomonas exibiram capacidade de remoção de $77 \%$ de $\mathrm{Pu}, 92 \%$ de $\mathrm{Np}, 76 \%$ de $\mathrm{U}, 72 \%$ de Am e, $33 \%$ de Sr. Foram usadas soluções com concentrações iniciais de $1 \times 10^{-10} \mathrm{M}$ de ${ }^{90} \mathrm{Sr}, 10^{-9} \mathrm{M}$ de ${ }^{137} \mathrm{Cs}, 6 \times 10^{-10} \mathrm{de}$ ${ }^{238} \mathrm{Pu}(\mathrm{IV}), 10^{-9} \mathrm{M}$ de ${ }^{241} \mathrm{Am}, 10^{-7} \mathrm{M}$ de ${ }^{233} \mathrm{U}$ (VI) e $1,02 \times 10^{-6} \mathrm{de}{ }^{237} \mathrm{~Np}(\mathrm{~V})$, com pH entre 5 e 6. 


\section{METODOLOGIA}

O presente trabalho foi desenvolvido em duas etapas fundamentais: biossorção e bioarremoção por bactérias.

Na primeira etapa, foram utilizadas micro esferas de alginato de cálcio, células livres de Saccharomyces cerevisiae inativadas por radiação e imobilizadas em alginato de cálcio. Na segunda etapa, foram utilizadas as bactérias Ochrobactrum anthropi, Cupriavidus metallidurans e Bacillus subtilis.

A avaliação do potencial de remoção de ${ }^{241} \mathrm{Am}$ por biossorção e biorremoção, foi realizada pelo método de batelada, colocando-se uma solução de ${ }^{241} \mathrm{Am}$ de concentração conhecida em contato com os biossorventes e, estudados os seguintes parâmetros: $\mathrm{pH}$, tempo de contato e concentração.

Antes de serem realizados os experimentos de biorremoção com as bactérias, foram feitos os estudos de: curva de crescimento e C.I.M. (Concentração Inibitória Mínima) e viabilidade celular para dose letal 50\% (DL$50)$.

A quantificação do ${ }^{241} \mathrm{Am}$ residual da primeira etapa, foi realizada por espectrômetro de radiação gama, marca Canberra, modelo GX2518 e, para os experimentos de biorremoção, as análises do amerício residual foram feitas em aparelho Tri-carb 2100 TR - Liquid Scintillation Analyzer da Packard-Canberra.

A determinação da viabilidade celular foi realizada em Citômetro de fluxo FACScalibur, Bencton-Dickinson.

Foram utilizados materiais básicos para o trabalho com micro-organismos como peneira Tyler 200, frascos de polietileno $220 \mathrm{~mL}$, frascos de $22 \mathrm{~mL}$, Erlenmeyers, Béqueres, filtro de papel, bureta, pipetas e ponteiras descartáveis, agitador magnético, espectrômetro, espectrofotômetro Ultrospec 3000 UV/Visible Spectrophotometer - Pharmacia Biotech, pHmetro, balança semi-analítica, mesa agitadora marca Itasul, autoclave marca Phoenix modelo AV18, cronômetro, microscópio, pipetadores automáticos, bomba peristáltica, estufa agitadora, centrífuga, bico de Bunsen, luvas descartáveis, tubos Falcon $15 \mathrm{~mL}$ e $50 \mathrm{~mL}$. 


\subsection{Biossorção}

\subsubsection{Biossorção por Saccharomyces cerevisiae livres}

A Saccharomyces cerevisiae utilizada é da marca comercial Lassaffre, SAF Argentina. A solução de amerício é da marca Amersham. A inativação celular foi feita com radiação gama (5kGy) e, a verificação da morte celular, feita pelos testes de coloração com azul de metileno (LEE, 1981), figuras 11 e 12, e inoculação em meio sólido de YEPD (1\% de Extrato de Levedura, 1\% de Peptona, 2\% de Dextrose e 2\% de Ágar).

A concentração de biomassa aplicada na biossorção foi baseada na literatura (ITOH et al., 1975; VOLESKY et al., 1993; KEDARI et al., 2001), ou seja, $2 \%$ de massa/volume de solução. As células livres de Saccharomyces cerevisiae inativadas foram colocadas em frascos de polietileno contendo $60 \mathrm{~mL}$ de solução

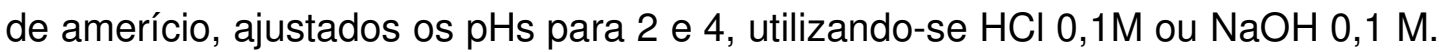
Os frascos foram mantidos sob agitação constante à temperatura ambiente por 30, 60, 120 e 240 minutos. As concentrações das soluções foram de 75, 150 e $300 \mathrm{~Bq} / \mathrm{mL}$. Após os tempos de contato, as soluções foram centrifugadas durante 15 minutos a 2500 giros/min., coletados $50 \mathrm{~mL}$ do sobrenadante e colocados em frascos de polietileno de $220 \mathrm{~mL}$ para contagem da radiação residual em espectrômetro de radiação gama. Todos os experimentos foram realizados em duplicata.

A figura 11 apresenta o fluxograma dos experimentos de biossorção. 


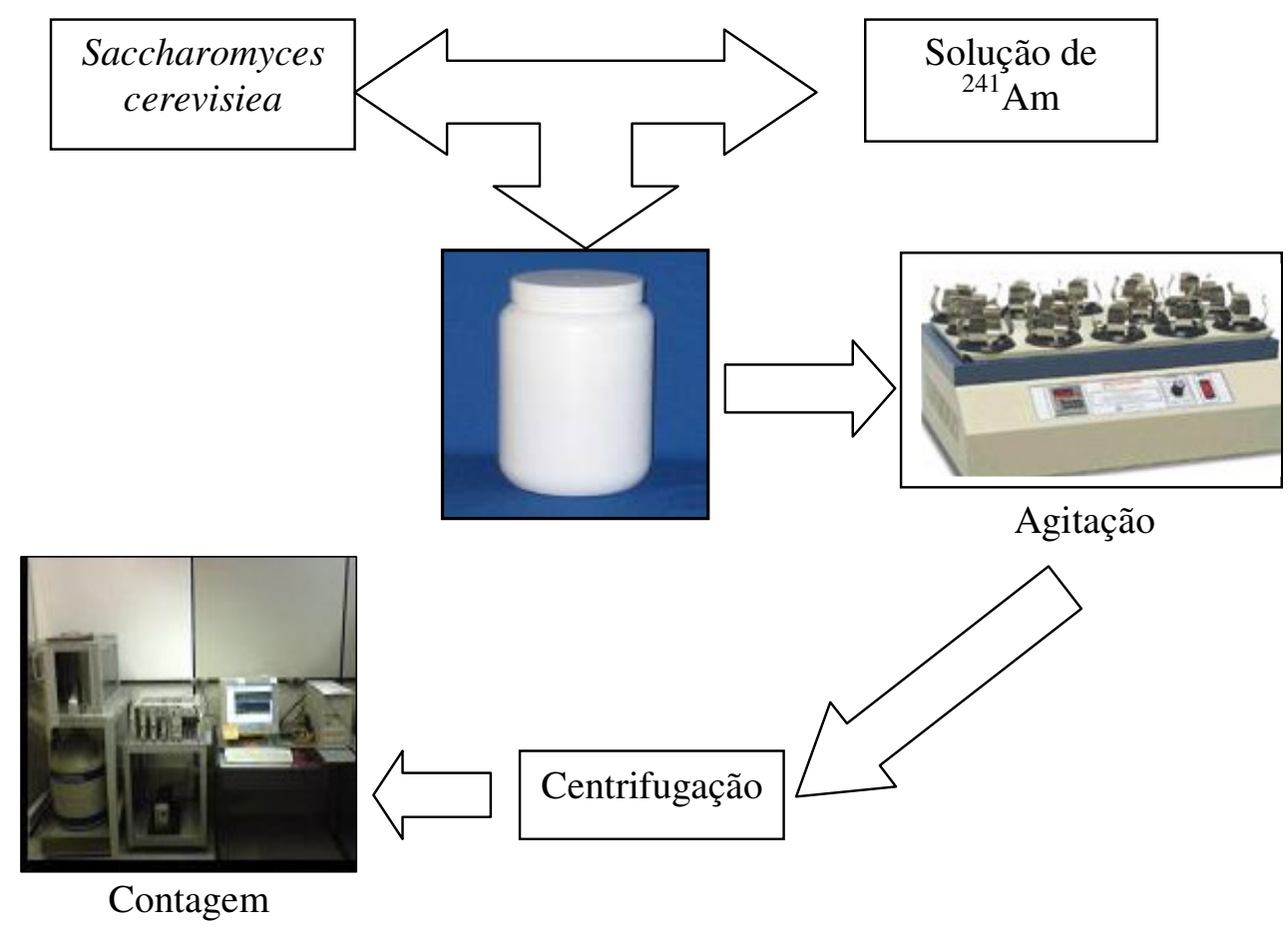

Figura 11 - Fluxograma dos experimentos de biossorção.

\subsubsection{Biossorção por Saccharomyces cerevisiae imobilizadas em micro esferas de alginato de cálcio}

Saccharomyces cerevisiae foram imobilizadas em micro esferas de alginato de cálcio, seguindo a metodologia proposta por GÖKSUNGUR et al. 2003.

As micro esferas foram preparadas com $100 \mathrm{~mL}$ de água deionizada em um Béquer e acrescentados $2 \mathrm{~g}$ de alginato de sódio. Após a homogeneização, foram acrescentados $2 \mathrm{~g}$ de células de Saccharomyces cerevisiae e, novamente a solução foi homogeneizada. Em outro Béquer foi preparada uma solução com 400 $\mathrm{mL}$ de água deionizada adicionando-se $16 \mathrm{~g}$ de cloreto de cálcio.

A solução de alginato de sódio com Saccharomyces cerevisiae foi adicionada lentamente na solução de cloreto de cálcio com o auxílio de uma bomba peristáltica.

Ao final, as micro esferas foram separadas da solução de cloreto de cálcio utilizando-se uma peneira Tyler 200 e lavadas por 4 vezes com água deionizada para a remoção total dos íons de cálcio livres. 
Os experimentos de biossorção com Saccharomyces cerevisiae inativadas e imobilizadas em alginato de cálcio foram realizados como descrito no item 4.1, acrescentando-se em substituição à Saccharomyces cerevisiae, 1,2 g de micro esferas de alginato de cálcio contendo a levedura inativa.

\subsubsection{Biossorção por micro esferas de alginato de cálcio}

As micro esferas de alginato de cálcio foram preparadas como descrito no item anterior, apenas sem o acréscimo de Saccharomyces cerevisiae (figura 12).

A concentração de biomassa aplicada na biossorção e todos os demais procedimentos foram mantidos.

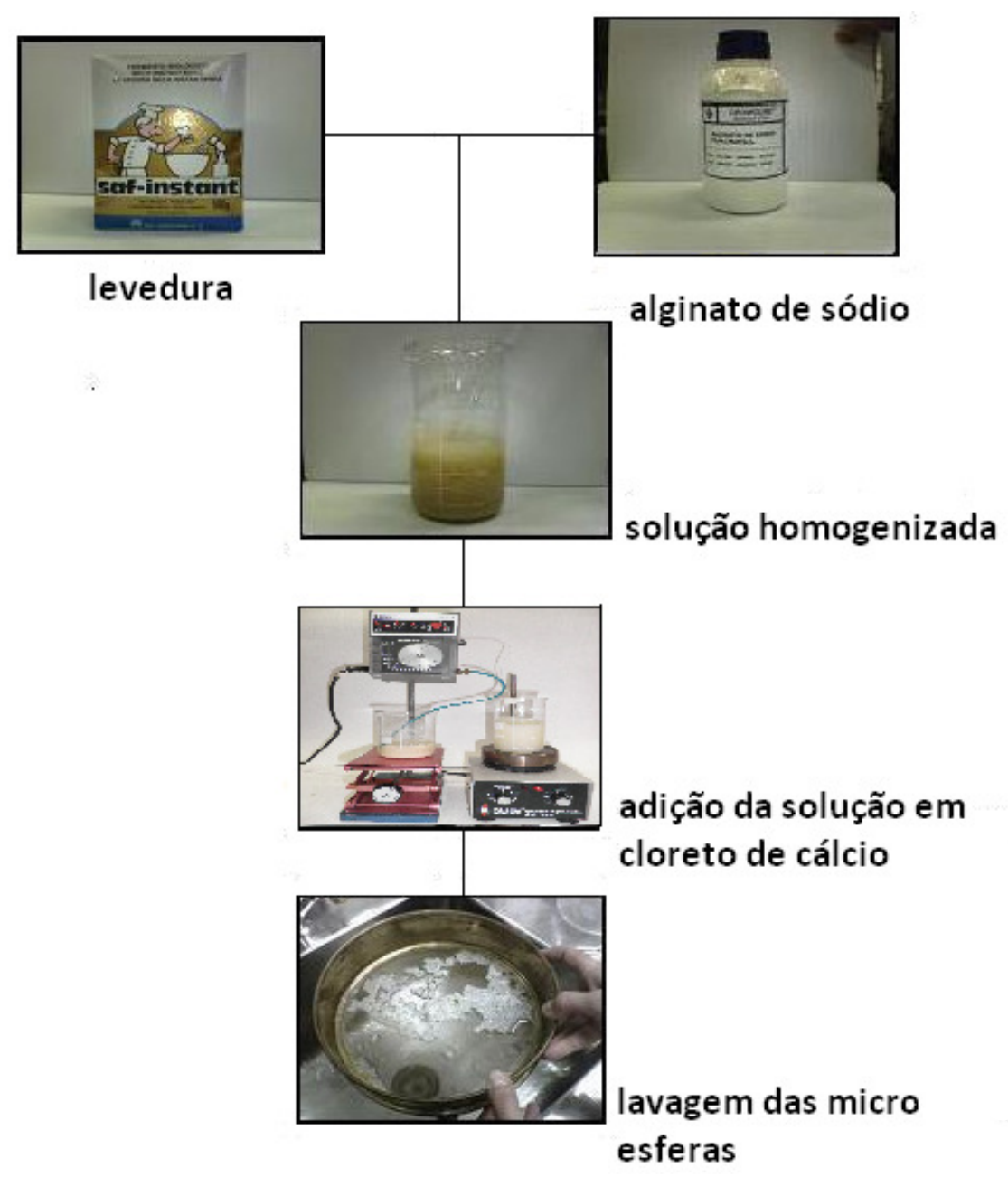

Figura 12 - Fluxograma imobilização de Saccharomyces cerevisiae em micro esferas de alginato de cálcio . 


\subsection{Biorremoção por bactérias}

\subsubsection{Cultura de bactérias}

\section{Ochrobactrum anthropi}

Ochrobactrum anthropi foi isolada do chorume coletado dos lisímetros montados para a realização dos experimentos de "Avaliação da contaminação provocada por pára-raios radioativos de Amerício-241" (MARUMO, 2006), por (FERREIRA et al., 2009), realizados no Laboratório de Rejeitos Radioativos do Instituto de Pesquisas Energéticas e Nucleares - IPEN/SP.

A bactéria Ochrobactrum anthropi foi cultivada em meio rico cérebrocoração (Difco) durante 24 horas em estufa a $37^{\circ} \mathrm{C}$ sob agitação constante.

\section{Bacillus subtilis}

Uma cepa de Bacillus subtilis foi fornecida pelo Instituto de Biociências da Universidade de São Paulo e cultivada no Laboratório de Rejeitos Radioativos do IPEN/CNEN-SP, em meio rico cérebro-coração (Difco) durante 24 horas em estufa a $37^{\circ} \mathrm{C}$ sob agitação constante.

\section{Cupriavidus metallidurans}

Esta bactéria foi fornecida e cultivada pelo Instituto de Biociências da Universidade de São Paulo. A cepa de Cupriavidus metallidurans foi cultivada sob condições aeróbias em caldo nutriente $(\mathrm{CN})$ a $28 \stackrel{\circ}{ } \mathrm{C}$, conforme especificado pela coleção de culturas, segundo Mergeay et al. (1985). 


\subsubsection{C.I.M. - Concentração Inibitória Mínima}

O estudo do C.I.M. (Concentração Inibitória Mínima), ou M.I.C. ("Minimum Inhibitory Concentration") em inglês, foi realizado para as três bactérias estudadas com o objetivo de determinar a quantidade mínima de ${ }^{241} \mathrm{Am}$ capaz de inibir o crescimento dos micro-organismos, seguindo a metodologia descrita em NCCLS,2003.

Foi utilizado o método de diluições sucessivas, e todos os experimentos foram plaqueados em triplicata.

\subsubsection{Cultura de bactérias para o C.I.M.}

Para cada uma das bactérias, foi preparado um pré-inóculo em Béqueres de $250 \mathrm{~mL}$ de capacidade, com $100 \mathrm{~mL}$ de meio de cultura cérebro-coração (BHIBrain Heart Infusion) e autoclavados. Com uma alça de platina esterilizada por flambagem de chama direta, foi inoculada uma pequena porção do microorganismo a ser cultivado .

Os pré-inóculos foram mantidos em estufa a $37^{\circ} \mathrm{C}$ sob agitação constante por 24 horas e, $1 \mathrm{~mL}$ de cada pré-inóculo foi transferido, em condições estéreis, para Béqueres de $1000 \mathrm{~mL}$ de capacidade, contendo $500 \mathrm{~mL}$ de meio de cultura cérebro-coração previamente autoclavados. Os meios foram mantidos em estufa a $37^{\circ} \mathrm{C}$ sob agitação constante por 24 horas.

\subsubsection{Preparo da solução de ${ }^{241} \mathrm{Am}$ em meio TSM}

O meio mínimo TSM-Tris Médium, foi preparado de acordo com o procedimento descrito por Mergeay et al, 1985.

Para $1 \mathrm{~L}$ de meio líquido.

Tris $6,06 \mathrm{~g}$

$\mathrm{MgCl}_{2}$ $0,20 \mathrm{~g}$

$\mathrm{CaCl}_{2}$ $0,03 \mathrm{~g}$

$\mathrm{NaCl}$ $4,68 \mathrm{~g}$ 

$\mathrm{KCl}$.
$1,49 \mathrm{~g}$
$\mathrm{NH}_{4} \mathrm{Cl}$
$1,07 \mathrm{~g}$
$\left(\mathrm{NH}_{4}\right)_{2} \mathrm{Fe}$ citrato
$0,005 \mathrm{~g}$
$\mathrm{Na}_{2} \mathrm{SO}_{4}$
$0,43 \mathrm{~g}$
$\mathrm{Na}_{2} \mathrm{HPO}_{4} .12 \mathrm{H}_{2} \mathrm{O}$
$0,23 \mathrm{~g}$
Gluconato. $2,00 \mathrm{~g}$
S. E. T.(1X) $1 \mathrm{~mL}$
$\mathrm{O}$ pH foi ajustado e a solução foi autoclavada. Em seguida foi adicionada a solução de elementos traços.
SOLUÇÃO DE ELEMENTOS TRAÇOS (S.E.T.) 10X
$\mathrm{HCl} 25 \%$ $1,3 \mathrm{~mL}$
$\mathrm{ZnSO}_{4} \cdot 7 \mathrm{H}_{2} \mathrm{O}$ $144 \mathrm{mg} / \mathrm{L}$
$\mathrm{MnCl}_{2}$. $4 \mathrm{H}_{2} \mathrm{O}$. $100 \mathrm{mg} / \mathrm{L}$
$\mathrm{H}_{3} \mathrm{BO}_{3}$ $62 \mathrm{mg} / \mathrm{L}$
$\mathrm{CoCl}_{2} \cdot 6 \mathrm{H}_{2} \mathrm{O}$ $190 \mathrm{mg} / \mathrm{L}$
$\mathrm{CuCl}_{2} \quad .2 \mathrm{H}_{2} \mathrm{O}$ $17 \mathrm{mg} / \mathrm{L}$
$\mathrm{NiCl}_{2} \cdot 6 \mathrm{H}_{2} \mathrm{O}$ $24 \mathrm{mg} / \mathrm{L}$
$\mathrm{Na}_{2} \mathrm{MoO}_{4} \cdot 2 \mathrm{H}_{2} \mathrm{O}$ $36 \mathrm{mg} / \mathrm{L}$

\subsubsection{Preparo das soluções de ${ }^{241} \mathrm{Am}$ para o C.I.M.}

Foram preparadas soluções de ${ }^{241} \mathrm{Am}$ em meio mínimo TSM, com atividades de 20, 40, 80, 120, 150, 175, 200, 225, 250, 300, 350, 400, 450, 800, $1000,1200,1400$ e 1800 e $2000 \mathrm{~Bq} / \mathrm{mL}$, a partir da solução padrão de 2450,50 $\mathrm{Bq} / \mathrm{mL}$. As faixas de tolerância estudadas foram de $7 \times 10^{-4}(20)$ a $6 \times 10^{-2}(2000) \mu \mathrm{M}$ $(\mathrm{Bq} / \mathrm{mL}) \mathrm{AmCl}_{3}$.

\subsubsection{Experimentos de C.I.M.}

Foram retirados $50 \mathrm{~mL}$ de cada cultura e centrifugados, o sobrenadante foi desprezado e os pellets foram ressuspendidos com meio TSM. Este procedimento 
foi realizado por mais duas vezes a fim de eliminar o meio de cultura. A densidade óptica (D.O.) das bactérias em meio TSM foi ajustada para 1.

Em frascos de quartzo de $22 \mathrm{~mL}$ de capacidade, previamente autoclavados, foram colocados $9 \mathrm{~mL}$ de Meio TSM $(\mathrm{pH} 7$ para Ochrobactrum anthropi e Bacillus subtilis e $\mathrm{pH} 5$ para Cupriavidus metallidurans) e, acrescentados $1 \mathrm{~mL}$ de TSM contendo bactérias. As diluições foram feitas até $10^{-8}$ de acordo com National Committee for Clinical Laboratories Standards (NCCLS, 2003).

Essas amostras foram mantidas em estufa por 24 horas sob agitação constante. Após este período, foi feito o plaqueamento e observado após 24 horas de incubação em estufa a $37^{\circ} \mathrm{C}$. Os resultados dos experimentos do C.I.M. estão representados na tabela 4.

\subsection{Curvas de crescimento das bactérias}

Foram preparadas as culturas das três cepas bacterianas, para o estudo da curva de crescimento, do mesmo modo descrito nos experimentos de C.I.M. Para cada cepa foram feitas culturas em triplicatas.

Após a inoculação do pré-inóculo nos meios de cultura, as concentrações celulares foram estimadas densidade óptica em comprimento de onda de $600 \mathrm{~nm}$. A absorbância foi verificada a cada 1 hora, até 10 horas. (MADIGAN, 2008).

\subsection{Viabilidade celular}

O teste de viabilidade celular foi realizado por meio da técnica de citometria de fluxo ${ }^{1}$. Utilizou-se rodamina 123 para detectar a viabilidade celular por meio da atividade respiratória (JEPRAS, 1995). Este teste foi realizado para confirmação

\footnotetext{
${ }^{1}$ A citometria de fluxo é uma técnica analítica quantitativa que fornece resultados rápidos sobre algumas características estruturais e funcionais de células e organelas em suspensão. A técnica emprega um aparelho que avalia a emissão de fluorescência das células por meio do uso da radiação laser, fluxo hidrodinâmico, óptica, substâncias fluorescentes e recursos de informática (FALDYNA, 2001; WILKERSON, 2004). O funcionamento dos citômetros baseia-se na aspiração de uma suspensão de células e formação de um fluxo contínuo que passa por feixes perpendiculares de lasers. Uma vez interceptada pelo laser, fenômenos físicos ocorrem e uma parte da luz sofre dispersão, que é detectada diretamente por fotodiodos. A avaliação da dispersão da luz permite obter dados importantes como dimensões celulares, granulosidade/complexidade, morfologia e atividade respiratória. A citometria de fluxo permite análise simultânea de diversas características celulares por um grande número de eventos e, além disso, avalia concomitantemente os aspectos morfológicos, fenotípicos e funcionais, conferindo significado estatístico mesmo em fenômenos raros não detectáveis por outras metodologias (GRINDEM, 1996). Bactérias viáveis acumulam rodamina 123 e, as não viáveis não têm essa capacidade. Sob condições apropriadas elas absorvem rodamina 123 e, refletem quantitativamente a extensão da sua viabilidade (JEPRAS et al., 1995).
} 
do C.I.M. e avaliação do processo de remoção do amerício, uma vez que a bioacumualção só ocorre com células viáveis.

\subsection{Experimentos de biorremoção}

Para cada experimento, em condições assépticas e, utilizando-se materiais esterilizados, uma alíquota de cada cultura de bactérias foi coletada em tubo Falcon, centrifugada por 15 minutos a 2500 giros $/ \mathrm{min}$. O sobrenadante foi desprezado e, em seguida, os pellets foram ressuspendidos em meio TSM em pH 7 para Ochrobactrum anthropi e Bacillus subtilis e TSM em pH 5 para Cupriavidus metallidurans e centrifugados durante 15 minutos a 2500 giros $/ \mathrm{min}$., por duas vezes, a fim de remover o meio de cultura. Foi feito o ajuste da D.O. para 2,5.

As soluções de ${ }^{241} \mathrm{Am}$ foram preparadas com meio TSM em pH 7 e pH 5, nas concentrações $600 \mathrm{~Bq} / \mathrm{mL}, 300 \mathrm{~Bq} / \mathrm{mL}$ e $150 \mathrm{~Bq} / \mathrm{mL}$, a partir da solução padrão com atividade de $23.229,4 \mathrm{~Bq} / \mathrm{mL}$, certificado pelo IRD - Instituto de Radioproteção e Dosimetria CNEN-RJ.

Os experimentos de biorremoção foram realizados com $1,5 \mathrm{~mL}$ de solução de TSM contendo ${ }^{241} \mathrm{Am}$ nas concentrações desejadas e $1,5 \mathrm{~mL}$ de solução de TSM contendo bactérias.

As soluções foram colocadas em frascos de quartzo de $22 \mathrm{~mL}$ de capacidade, previamente autoclavados, em condições estéreis. Os frascos foram acondicionados em sacos plásticos, colocados dentro de frascos de polietileno e mantidos sob agitação constante, a temperatura ambiente por 1, 2, 4, 6, 12 e 24 horas para Cupriavidus metallidurans, por 2, 5, 30, 60, 120, 240, 360, 720 e 1440 min. para Ochrobactrum anthropi e, para os experimentos com Bacillus subtilis, o tempo de contato foi de 6, 12 e 24 horas.

Após os tempos de contato, as soluções foram centrifugadas a 2500 giros/min. por 15 minutos e, $1 \mathrm{~mL}$ do sobrenadante foi separado para análise por cintilação.

A metodologia desta etapa foi realizada com adaptações de Li et al., 2008. 


\subsubsection{Preparo das amostras para análise}

O ${ }^{241} \mathrm{Am}$ residual foi analisado pela técnica de cintilação. Em frascos de quartzo de $22 \mathrm{ml}$ foram adicionados $1 \mathrm{~mL}$ da solução a ser analisada e $19 \mathrm{~mL}$ de líquido cintilador (PERRIER, 2004). A amostra foi agitada em vórtex por 1 minuto e colocada no cintilador durante 30 minutos.

\subsection{Medidas de segurança}

Todos os cuidados de proteção radiológica foram observados, utilizando-se os Equipamentos de Proteção Individual e o laboratório apropriado para o trabalho com materiais radioativos. As bancadas foram forradas e todo rejeito sólido gerado foi devidamente descartado após monitoração. 


\section{RESULTADOS E DISCUSSÕES}

\subsection{Resultados da viabilidade celular de Saccharomyces cerevisiae inativadas por radiação.}

A figura 13 mostra Saccharomyces cerevisiea vivas e a figura 14 demonstra a coloração azulada de Saccharomyces cerevisiae, indicando que as paredes celulares foram danificadas, favorecendo a entrada do corante azul de metileno, o que comprova a morte celular.

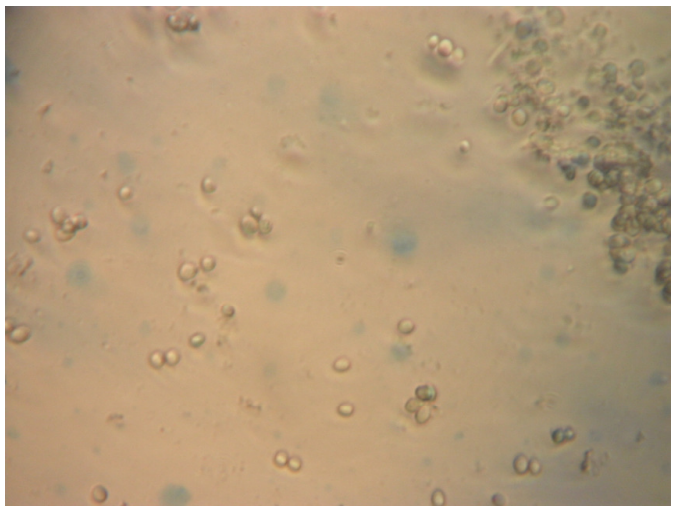

Fig. 13 Saccharomyces cerevisiae viva

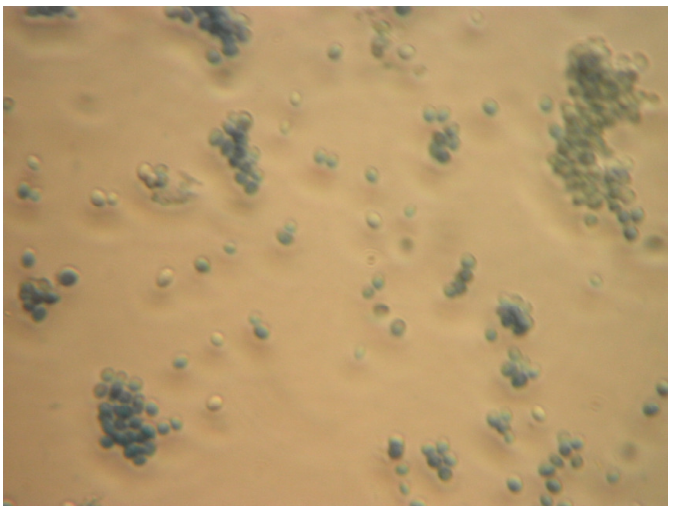

Fig. 14 Saccharomyces cerevisiae inativada por radiação

\subsection{Resultados de Biossorção}

\subsubsection{Biossorção de ${ }^{241} \mathrm{Am}$ por Saccharomyces cerevisiae livres inativadas}

As figuras 15, 16 e 17 apresentam os resultados dos experimentos de biossorção de ${ }^{241} \mathrm{Am}$ realizados com Saccharomyces cerevisiae livres e inativadas com as atividades de 75, 150 e $300 \mathrm{~Bq} / \mathrm{mL}$ em pH 2 e 4 .

Os experimentos com Saccharomyces cerevisiae livres em $\mathrm{pH} 2$ demonstraram remoção de $96,7 \%$ em 30 minutos de contato para solução de ${ }^{241} \mathrm{Am}$ com concentração inicial de $75 \mathrm{~Bq} / \mathrm{mL}$ (figura 15).

O processo de biossorção de amerício por Saccharomyces cerevisiae livres e inativadas com atividade de $150 \mathrm{~Bq} / \mathrm{mL}$ (figura 16) apresentou resultados muito semelhantes aos dos experimentos com atividade de $300 \mathrm{~Bq} / \mathrm{mL}$ (figura 17). 
A tabela 2 apresenta o resumo dos resultados obtidos dos experimentos realizados com Saccharomyces cerevisiae livres e inativadas.

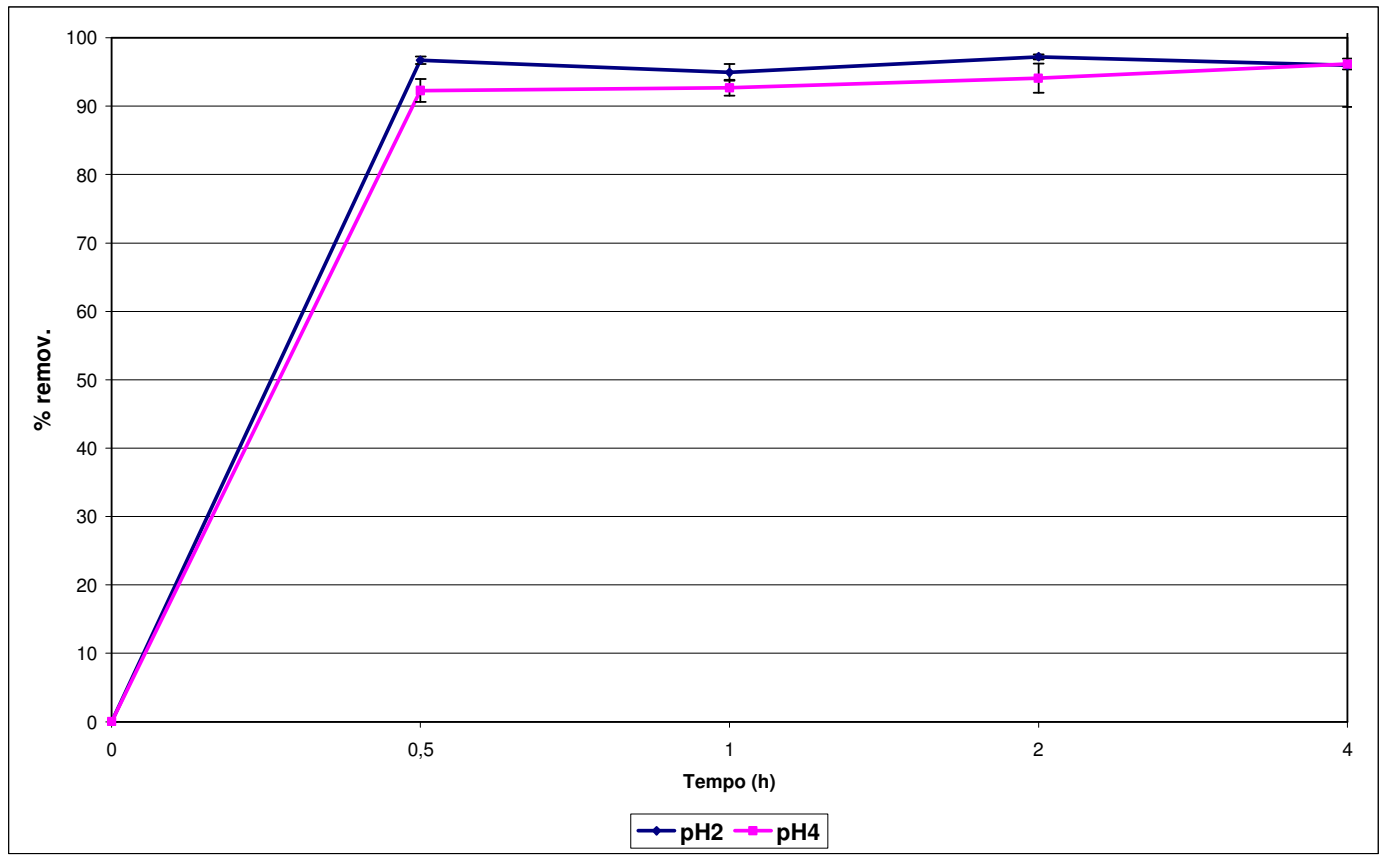

Figura 15 - Biossorção de ${ }^{241} \mathrm{Am}$ com concentração inicial de 75 Bq/mL, pH 2 e 4, por Saccharomyces cerevisiae livres inativadas.

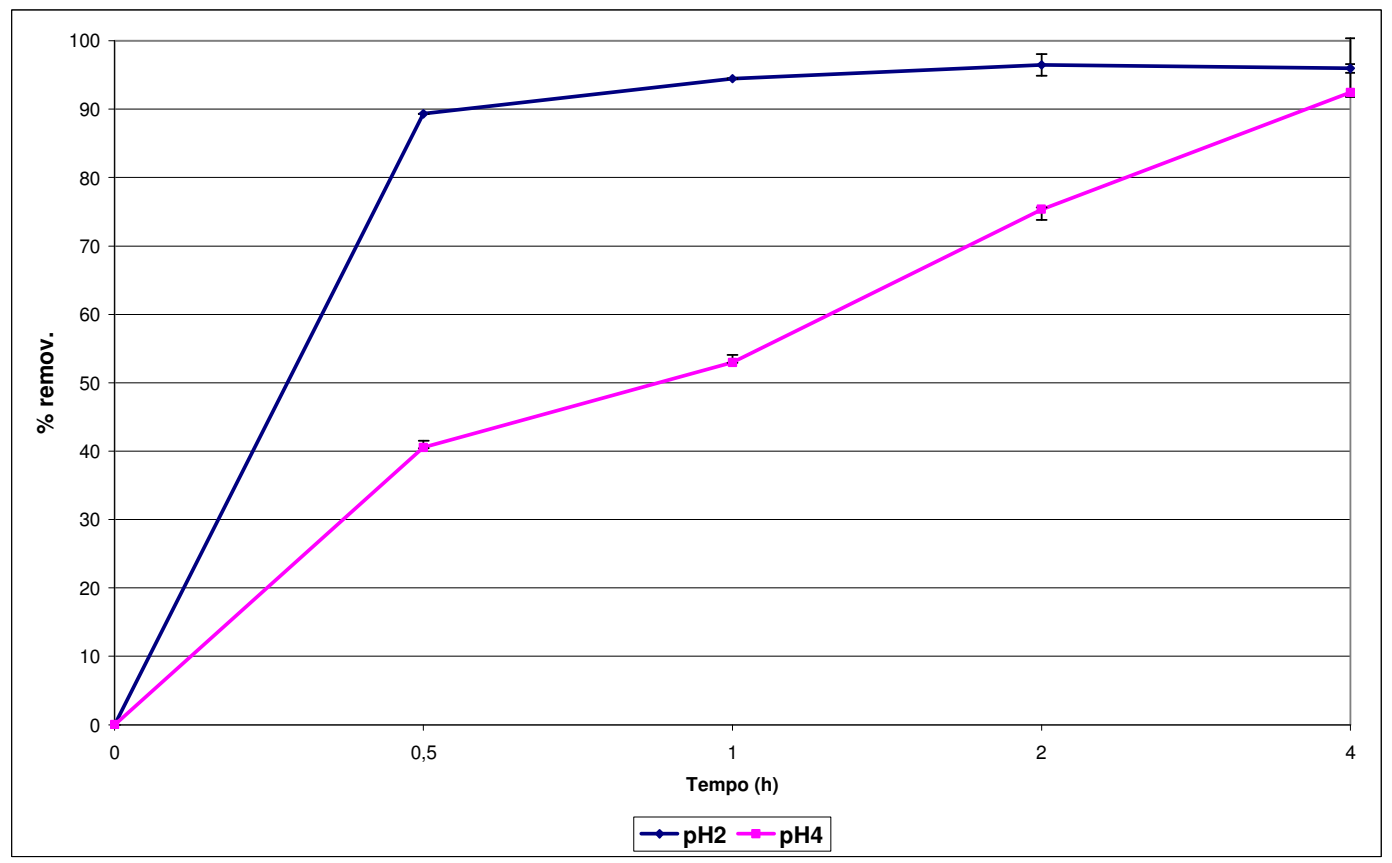

Figura 16 - Biossorção de ${ }^{241} \mathrm{Am}$ com concentração inicial de 150 Bq/mL, pH 2 e 4, por Saccharomyces cerevisiae livres e inativadas. 
Os resultados dos experimentos de biossorção realizados com Saccharomyces cerevisiae livres e inativadas em solução de ${ }^{241} \mathrm{Am}$ com concentração inicial de $300 \mathrm{~Bq} / \mathrm{mL}$ em pH 2 demonstraram que em 30 minutos de contato ocorreu remoção de $80,3 \%$, evoluindo até $97 \%$ após 240 minutos de contato (figura 17). A tabela 2 apresenta todos os resultados obtidos dos experimentos de biossorção de ${ }^{241} \mathrm{Am}$ por Saccharomyces cerevisiae livres e inativadas nas três concentrações estudadas.

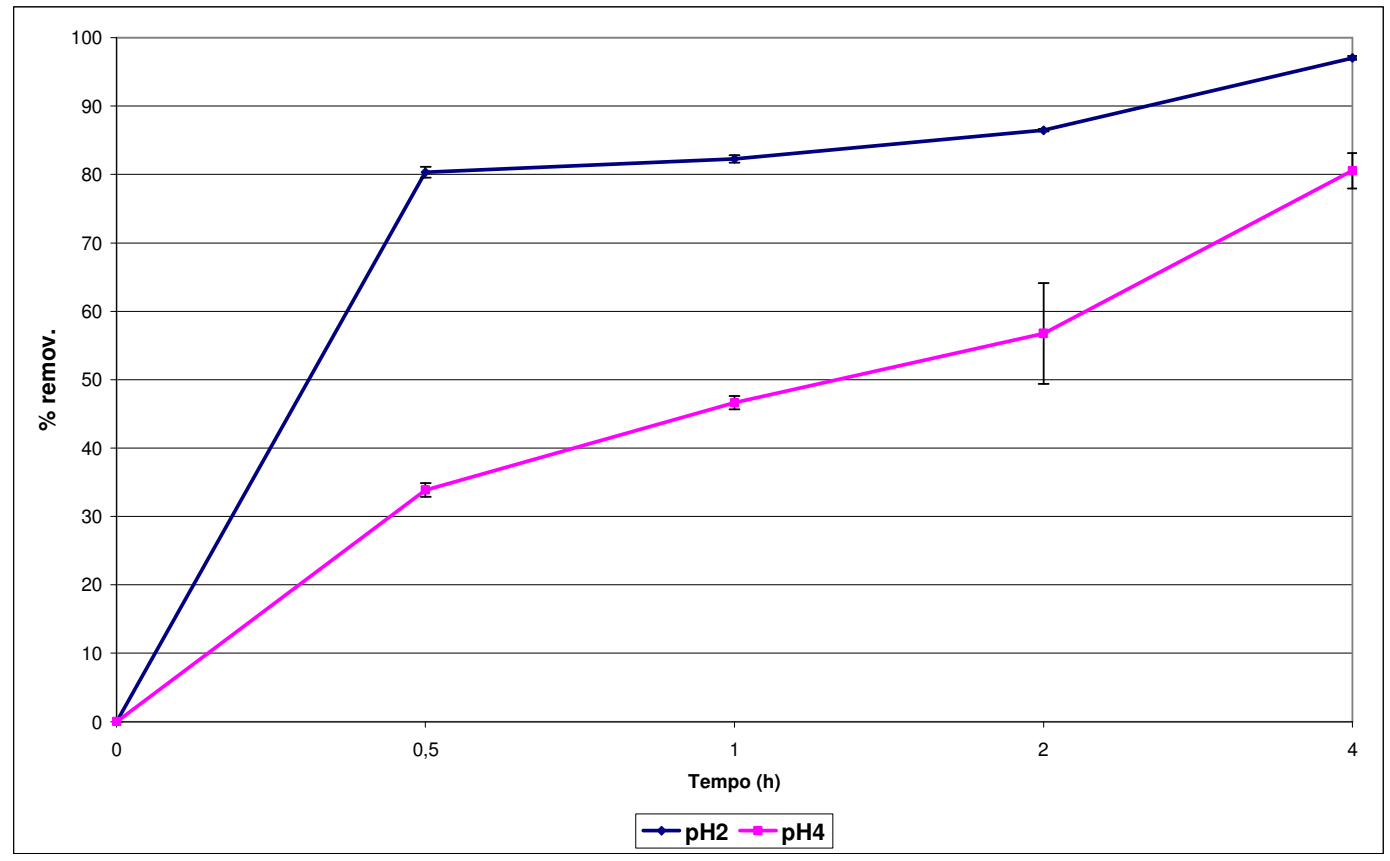

Figura 17 - Biossorção de ${ }^{241} \mathrm{Am}$ com concentração inicial de 300 Bq/mL, pH 2 e 4, por Saccharomyces cerevisiae livres e inativadas.

Tabela 2 - Biossorção de ${ }^{241} \mathrm{Am}$ por Saccharomyces cerevisiae livres e inativadas.

\begin{tabular}{ccccccc}
\hline \hline & & & & & \\
Tempo & $75 \mathrm{~Bq} / \mathrm{mL}$ & $75 \mathrm{~Bq} / \mathrm{mL}$ & $150 \mathrm{~Bq} / \mathrm{mL}$ & $150 \mathrm{~Bq} / \mathrm{mL}$ & $300 \mathrm{~Bq} / \mathrm{mL}$ & $300 \mathrm{~Bq} / \mathrm{mL}$ \\
$(\mathrm{h})$ & $\mathrm{pH} 2$ & $\mathrm{pH} 4$ & $\mathrm{pH} 2$ & $\mathrm{pH} 4$ & $\mathrm{pH} 2$ & $\mathrm{pH} 4$ \\
0,5 & $96,7 \pm 0,56$ & $92,3 \pm 1,68$ & $89,3 \pm 0,04$ & $40,5 \pm 0,98$ & $80,3 \pm 0,79$ & $33,9 \pm 0,99$ \\
1 & $94,9 \pm 1,22$ & $92,7 \pm 1,14$ & $94,4 \pm 0,06$ & $52,9 \pm 1,10$ & $82,3 \pm 0,53$ & $46,6 \pm 0,97$ \\
2 & $97,2 \pm 0,38$ & $94,1 \pm 2,14$ & $96,5 \pm 1,60$ & $75,4 \pm 0,28$ & $86,5 \pm 0,16$ & $56,8 \pm 7,37$ \\
4 & $96,0 \pm 6,07$ & $96,2 \pm 0,78$ & $95,9 \pm 0,61$ & $92,4 \pm 7,92$ & $97,0 \pm 0,28$ & $80,6 \pm 2,58$ \\
\hline \hline
\end{tabular}


Os resultados obtidos corroboram os descritos na literatura por Liu et al. (2002-b) que utilizaram Saccharomyces cerevisiae livres para biossorção de ${ }^{241} \mathrm{Am}$ em solução aquosa com concentrações iniciais de 2,22 MBq/l a 555,0 $\mathrm{MBq} / \mathrm{l} \mathrm{e}$, verificaram os efeitos do $\mathrm{pH}$, tempo de contato e temperatura. Os resultados demonstraram remoção de cerca de $99 \%$ do amerício após 60 minutos de contato em solução com pH entre 1 e 3 e temperatura entre 10 e $45^{\circ} \mathrm{C}$.

Ferreira et al. (2007) estudaram o uso de Saccharomyces cerevisiae para o tratamento de rejeitos radioativos contendo ${ }^{241} \mathrm{Am}$ e, constataram que em solução aquosa com concentração inicial de $15 \mathrm{~Bq} / \mathrm{mL}$, ocorre remoção de $99,9 \%$ de ${ }^{241} \mathrm{Am}$ após 15 minutos de contato em $\mathrm{pH} 2$.

\subsubsection{Biossorção de ${ }^{241} \mathrm{Am}$ por alginato de cálcio e por Saccharomyces cerevisiae imobilizadas.}

Os resultados obtidos nos experimentos de biossorção realizados com Saccharomyces cerevisiae inativadas imobilizadas em micro esferas de alginato de cálcio e somente com alginato de cálcio são apresentados nas figuras 18, 19 e 20. Os resultados demonstram alta capacidade de biossorção em pH 4, em ambas as condições.

Em todos os tempos estudados e atividades estudadas, a biossorção demonstra ser mais eficiente em pH 4. Em 60 minutos, a remoção média do ${ }^{241}$ Am por alginato de cálcio com Saccharomyces cerevisiae foi de $97,5 \%$. A partir de 120 minutos, os resultados revelaram média de remoção de $97 \%$ tanto para alginato de cálcio com quanto sem Saccharomyces cerevisiae (figura 18). 


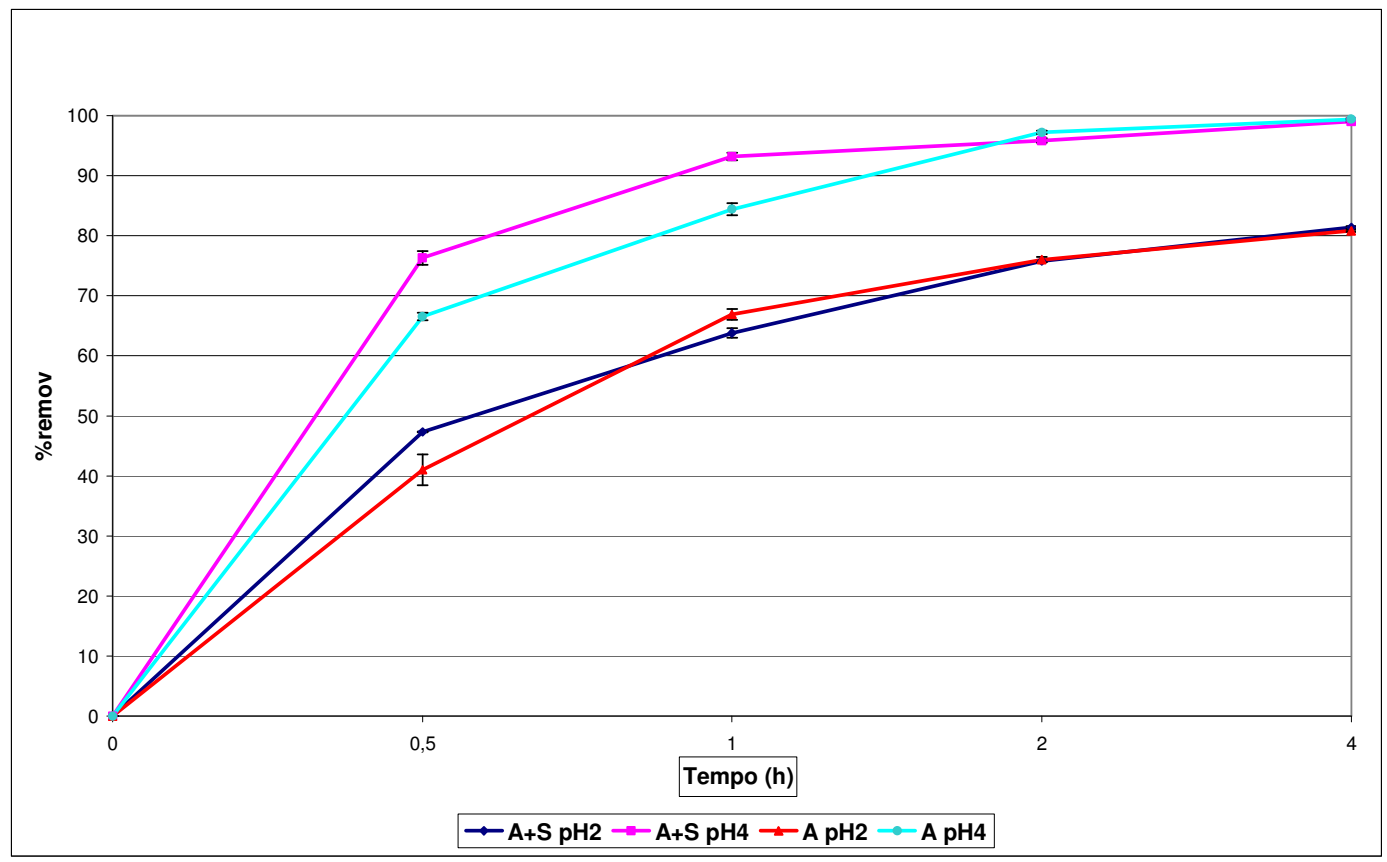

Figura 18 - Biossorção de ${ }^{241} \mathrm{Am}$ com concentração inicial de $75 \mathrm{~Bq} / \mathrm{mL}$ em pH 2 e 4 por A + S (alginato de cálcio com Saccharomyces cerevisiae) e A (alginato de cálcio).

Observa-se que em concentração de $150 \mathrm{~Bq} / \mathrm{mL}$ com pH 4 (figura 19), a biossorção apresenta resultados muito semelhantes quando realizada por alginato de cálcio com e sem Saccharomyces cerevisiae. Em 4 horas de contato, ocorre biossorção de 98,8 \% de Am-241 para solução em pH 4.

Nos experimentos com solução de amerício em pH 2, a biossorção máxima observada foi de $60,2 \%$ em 4 horas de contato. 


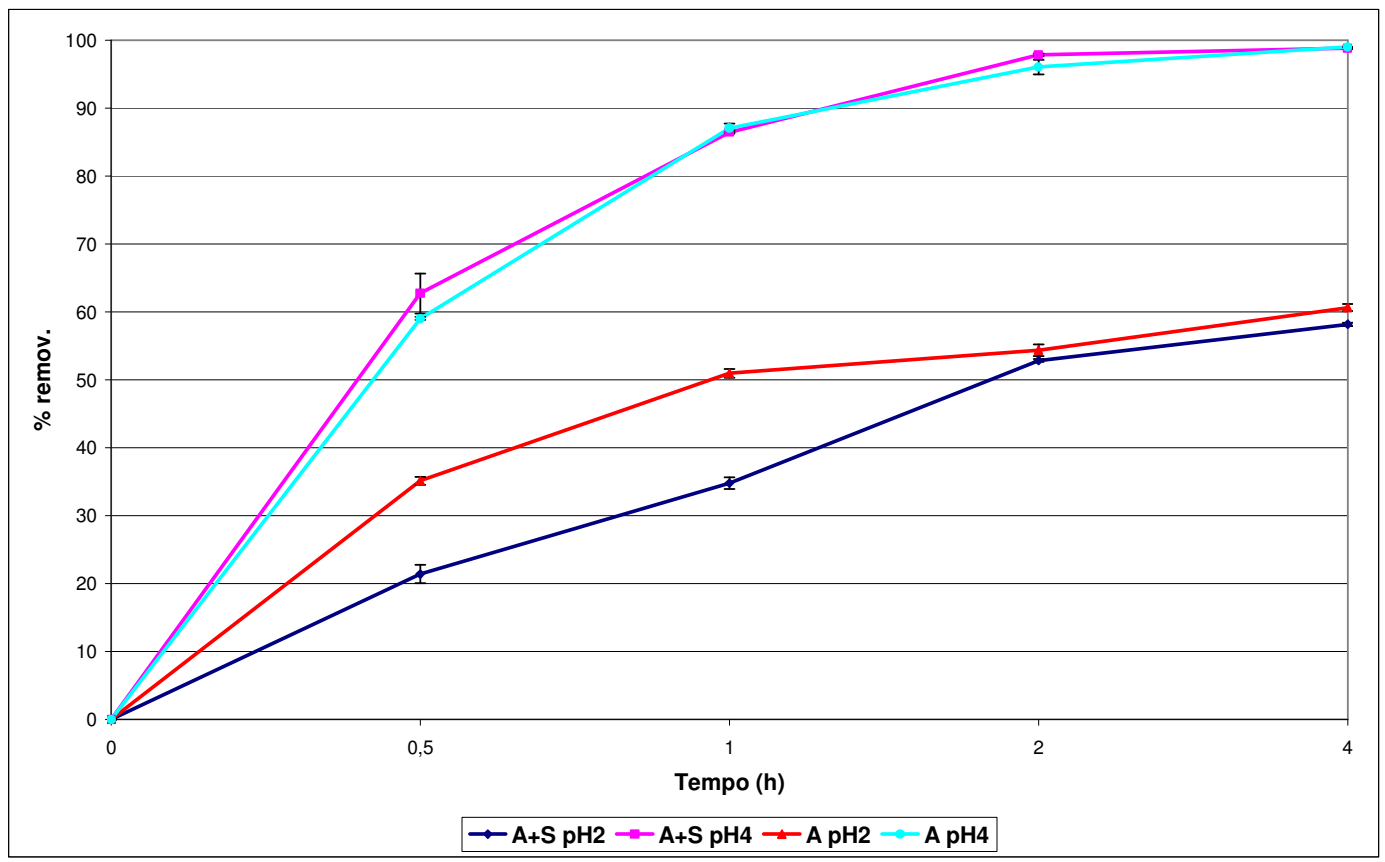

Figura 19 - Biossorção de ${ }^{241} \mathrm{Am}$ com concentração inicial de $150 \mathrm{~Bq} / \mathrm{mL}, \mathrm{pH} 2$ e 4, por A + S (alginato de cálcio com Saccharomyces cerevisiae) e A (alginato de cálcio).

Observa-se que em 60 minutos de contato em pH 4, somente o alginato de cálcio, Saccharomyces cerevisiae, 97,4\% do ${ }^{241} \mathrm{Am}$ com concentração inicial de $300 \mathrm{~Bq} / \mathrm{mL}$ e, o alginato com a levedura apresentam menor capacidade de biossorção $(81,7 \%)$ no mesmo tempo e pH (Figura 20).

A tabela 3 apresenta o resumo dos resultados obtidos de biossorção de ${ }^{241} \mathrm{Am}$ por $\mathrm{A}$ (alginato de cálcio) e por $\mathrm{A}+\mathrm{S}$ (Saccharomyces cerevisiae imobilizada em alginato de cálcio). 


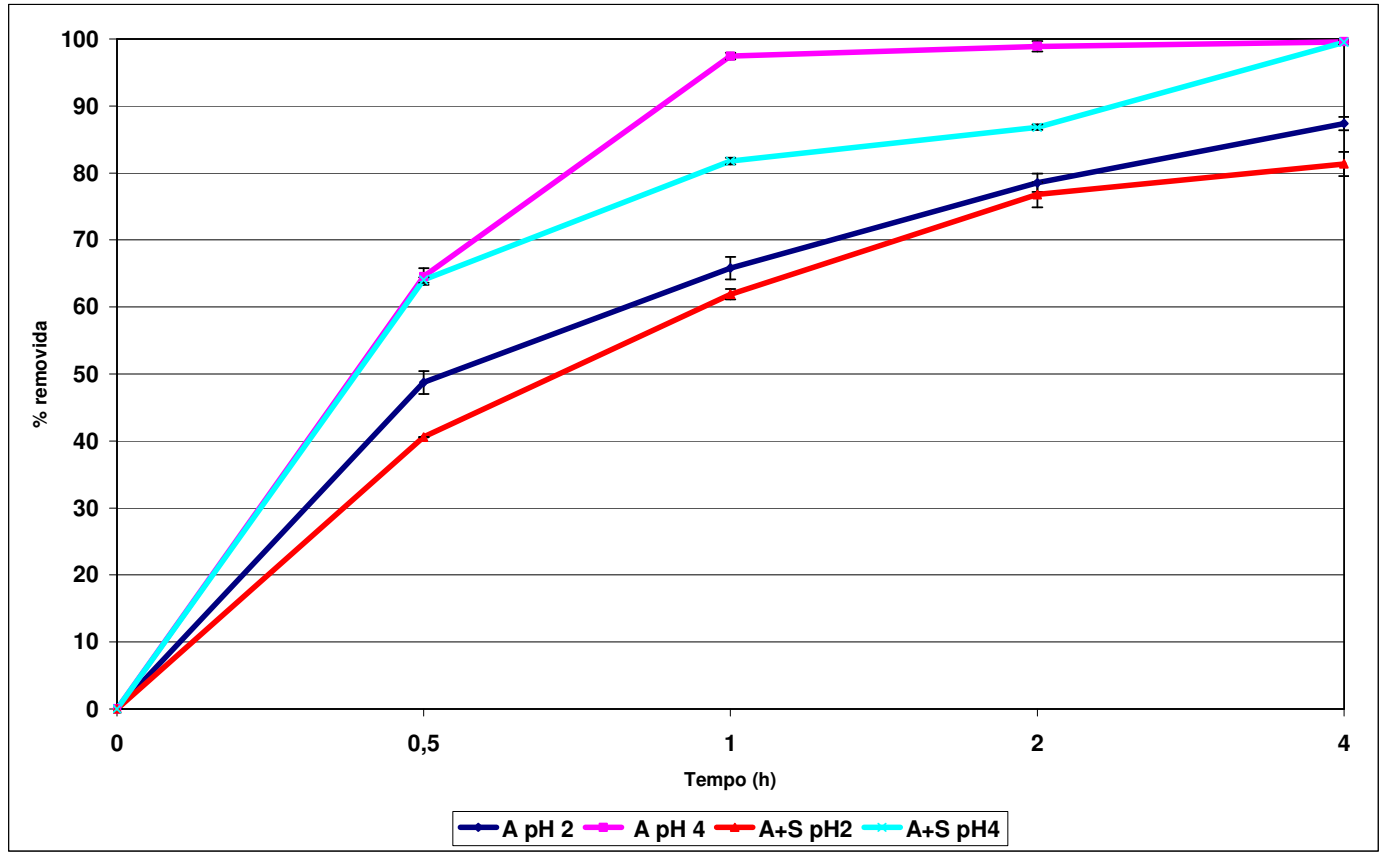

Figura 20 - Biossorção de ${ }^{241} \mathrm{Am}$ com concentração inicial de $300 \mathrm{~Bq} / \mathrm{mL}, \mathrm{pH} 2$ e 4, por A + S (alginato de cálcio com Saccharomyces cerevisiae) e A (alginato de cálcio).

Tabela 3. Biossorção de ${ }^{241} \mathrm{Am}$ por A(alginato de cálcio) e A+S (Saccharomyces cerevisiae imobilizada em alginato de cálcio)

\begin{tabular}{ccccc}
\hline \hline \multicolumn{5}{c}{$\mathbf{7 5 ~ B q / m L}$} \\
\hline Tempo (h) & $\mathrm{A} \mathrm{pH} 2$ & $\mathrm{~A} \mathrm{pH} \mathrm{4}$ & $\mathrm{A}+\mathrm{S} \mathrm{pH} 2$ & $\mathrm{~A}+\mathrm{S} \mathrm{pH} 4$ \\
0,5 & $47,3 \pm 0,09$ & $76,3 \pm 1,15$ & $41,0 \pm 2,6$ & $66,5 \pm 0,65$ \\
1 & $63,8 \pm 0,81$ & $93,2 \pm 0,64$ & $66,9 \pm 0,92$ & $84,4 \pm 0,98$ \\
2 & $75,8 \pm 0,18$ & $95,8 \pm 0,35$ & $76,0 \pm 0,47$ & $97,2 \pm 0,28$ \\
4 & $81,4 \pm 0,18$ & $99,0 \pm 0,07$ & $80,8 \pm 0,16$ & $99,4 \pm 0,13$ \\
\hline \hline \multicolumn{5}{c}{$\mathbf{1 5 0} \mathrm{Bq} / \mathbf{m L}$} \\
\hline 0,5 & $21,4 \pm 1,35$ & $62,7 \pm 2,96$ & $35,1 \pm 0,59$ & $59,0 \pm 0,22$ \\
1 & $34,8 \pm 0,87$ & $86,5 \pm 0,23$ & $50,9 \pm 0,64$ & $87,1 \pm 0,62$ \\
2 & $52,8 \pm 0,19$ & $97,8 \pm 0,20$ & $54,4 \pm 0,83$ & $96,0 \pm 1,07$ \\
4 & $58,1 \pm 0,25$ & $98,8 \pm 0,11$ & $60,6 \pm 0,51$ & $99,0 \pm 0,00$ \\
\hline \hline \multicolumn{5}{c}{$\mathbf{3 0 0} \mathrm{Bq} / \mathbf{m L}$} \\
\hline 0,5 & $48,7 \pm 1,70$ & $64,5 \pm 1,23$ & $40,5 \pm 0,01$ & $64,0 \pm 0,38$ \\
1 & $65,8 \pm 1,68$ & $97,4 \pm 0,49$ & $61,9 \pm 0,78$ & $81,7 \pm 0,49$ \\
4 & $78,5 \pm 1,33$ & $98,9 \pm 0,79$ & $76,7 \pm 1,86$ & $86,8 \pm 0,38$ \\
4 & $87,4 \pm 0,99$ & $99,6 \pm 0,05$ & $81,3 \pm 1,79$ & $99,5 \pm 0,33$ \\
\hline \hline
\end{tabular}

Os resultados obtidos dos experimentos com esferas de alginato de cálcio demonstraram que este biopolímero apresenta alta capacidade de remoção de ${ }^{241} \mathrm{Am}$, o que corrobora os resultados obtidos por Mimura et al. (2001), que 
obtiveram $90 \%$ de remoção de ${ }^{241} \mathrm{Am}$ de concentração inicial de $2,1 \cdot 10^{-9} \mathrm{M}$ em 24 horas de contato.

Em 2002 Mimura et al. verificaram que somente o alginato de cálcio remove simultaneamente cerca de $90 \%$ de vários radionuclídeos (Cs, Y, Co, Eu e Am) presentes em uma solução com concentração de $10 \mu \mathrm{g} / \mathrm{mL}$ após 19 horas de agitação, atingindo equilíbrio em 1 dia.

\subsection{Testes preliminares realizados com bactérias}

\subsubsection{Curvas de crescimento}

A figura 21 apresenta os resultados obtidos das curvas de crescimento e a tabela 4 demonstra os resultados obtidos da Concentração Inibitória Mínima (C.I.M.) das três bactérias utilizadas nos experimentos de bioacumulação.

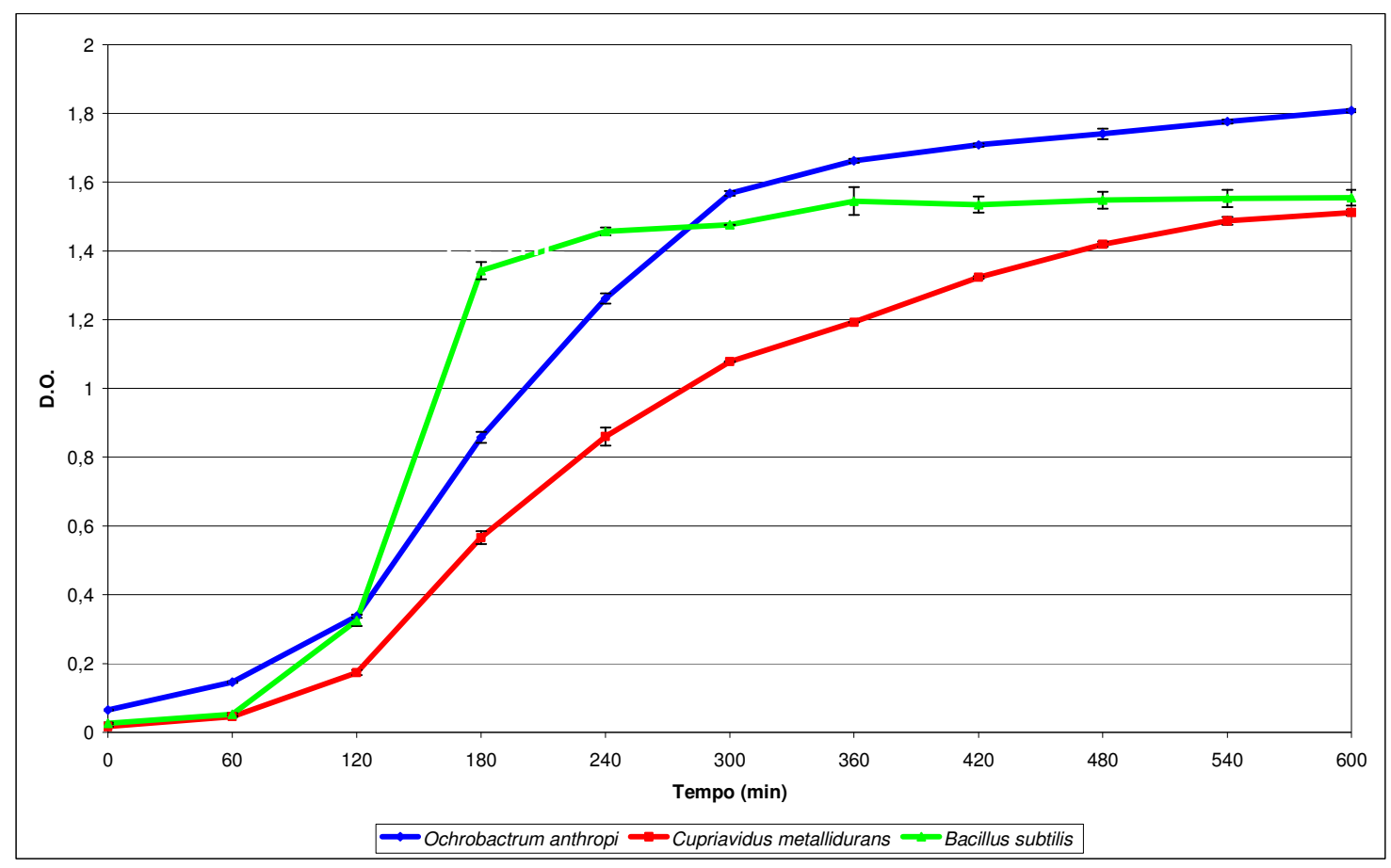

Figura 21 - Curvas de crescimento das bactérias Ochrobactrum anthropi, Cupriavidus metallidurans e Bacillus subtilis. 
Foi possível observar que a Bacillus subtilis foi a que teve o crescimento mais rápido e a Cupriavidus metallidurans a de crescimento mais lento das três bactérias estudadas.

\subsubsection{Concentração Inibitória Mínima}

Tabela 4 - Concentração Inibitória Mínima (C.I.M.) (+ = crescimento de bactérias/ - = ausência de crescimento de bactérias)

\begin{tabular}{cccc}
\hline \hline \multirow{2}{*}{ Atividade(Bq/mL) } & \multicolumn{4}{c}{ Resultado } \\
\cline { 2 - 4 } & $\begin{array}{c}\text { Cupriavidus } \\
\text { metallidurans }\end{array}$ & $\begin{array}{c}\text { Ochrobactrum } \\
\text { anthropi }\end{array}$ & $\begin{array}{c}\text { Bacillus } \\
\text { subtilis }\end{array}$ \\
\hline \hline 40 & + & + & + \\
80 & + & + & + \\
120 & + & + & + \\
150 & + & + & + \\
200 & + & + & + \\
250 & + & + & + \\
300 & + & + & + \\
350 & + & + & + \\
400 & + & + & + \\
500 & - & + & + \\
700 & - & + & + \\
800 & - & + & - \\
900 & - & + & - \\
1000 & - & + & - \\
1200 & - & + & - \\
1400 & - & - & - \\
\hline \hline
\end{tabular}

Os resultados dos experimentos para a determinação do C.I.M. das três bactérias em contato com ${ }^{241} \mathrm{Am}$ revelaram que a Ochrobactrum anthropi apresenta maior resistência ao amerício, ocorrendo crescimento de colônias quando as bactérias tiveram contato com a solução de amerício com $1200 \mathrm{~Bq}$ de atividade. Este comportamento pode ser explicado pelo fato desta bactéria ter tido contato prévio com o amerício no lisímetro de onde foi retirada (MARUMO, 2006).

A bactéria que apresentou maior sensibilidade ao ${ }^{241} \mathrm{Am}$ foi a Cupriavidus metallidurans com crescimento de colônias de bactérias em até $400 \mathrm{~Bq} \mathrm{de}{ }^{241} \mathrm{Am}$ e, a Bacillus subtilis apresentou crescimento de colônias de bactérias em até 700 Bq., provavelmente devido a formação de esporos. 


\subsubsection{Testes de viabilidade celular}

As figuras 22, 23 e 24 apresentam os resultados dos testes de viabilidade celular feitos a partir das bactérias que tiveram 5 horas de contato com DL-50 (dose letal para $50 \%$ da população) de amerício, analisados por da técnica de citometria de fluxo.

O resultado da avaliação de viabilidade celular por citometria de fluxo utilizando-se rodamina-123, que determina o potencial respiratório das bactérias, demonstrou que após 5 horas de contato da Cupriavidus metallidurans com a DL$50 \mathrm{de}{ }^{241} \mathrm{Am}(200 \mathrm{~Bq}), 49,66 \%$ das bactérias são viáveis (figura 20).

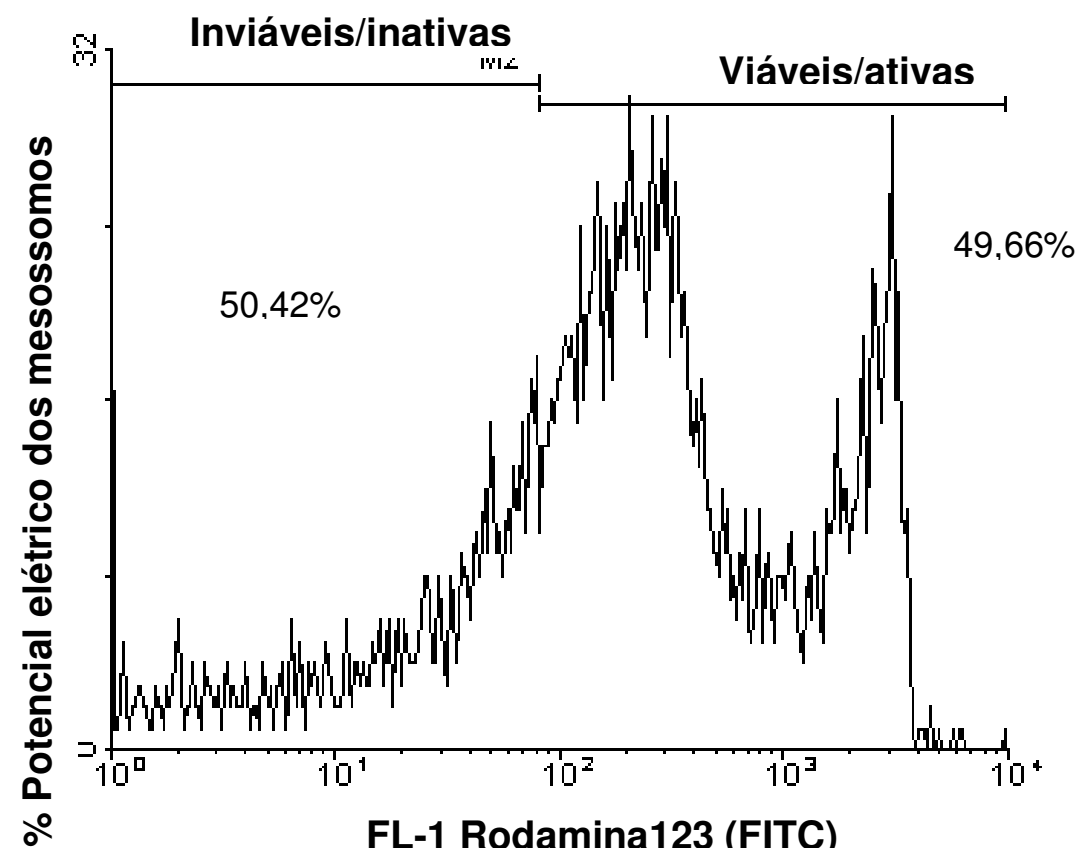

Figura 22 - Viabilidade da Cupriavidus após 5 h em contato com ${ }^{241} \mathrm{Am} / \mathrm{DL}-50$.

Através do resultado do teste de viabilidade celular da Ochrobactrum anthropi, constatou-se que $40,11 \%$ das bactérias permaneceram viáveis, após 5 horas de contato com solução DL-50 de ${ }^{241} \mathrm{Am}$ (600Bq) (figura 23). 


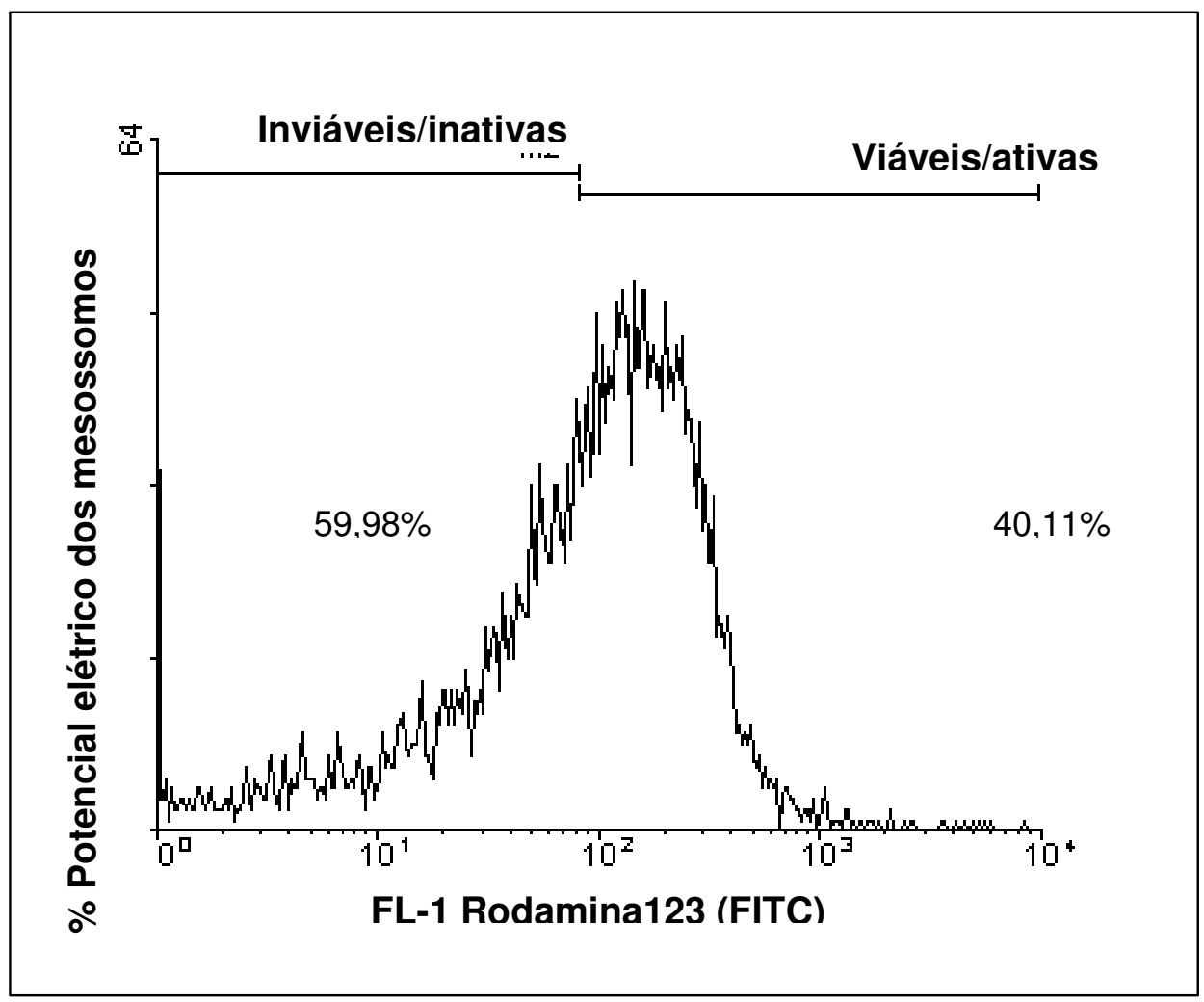

Figura 23 - Viabilidade da Ochrobactrum anthropi em contato com DL-50/ ${ }^{241} \mathrm{Am}$ por $5 \mathrm{~h}$.

O resultado do teste de viabilidade celular Bacillus subtilis demonstrou que $48,39 \%$ das bactérias expostas à DL-50 de ${ }^{241} \mathrm{Am}$ (350 Bq) permaneceram viáveis (figura 24). 


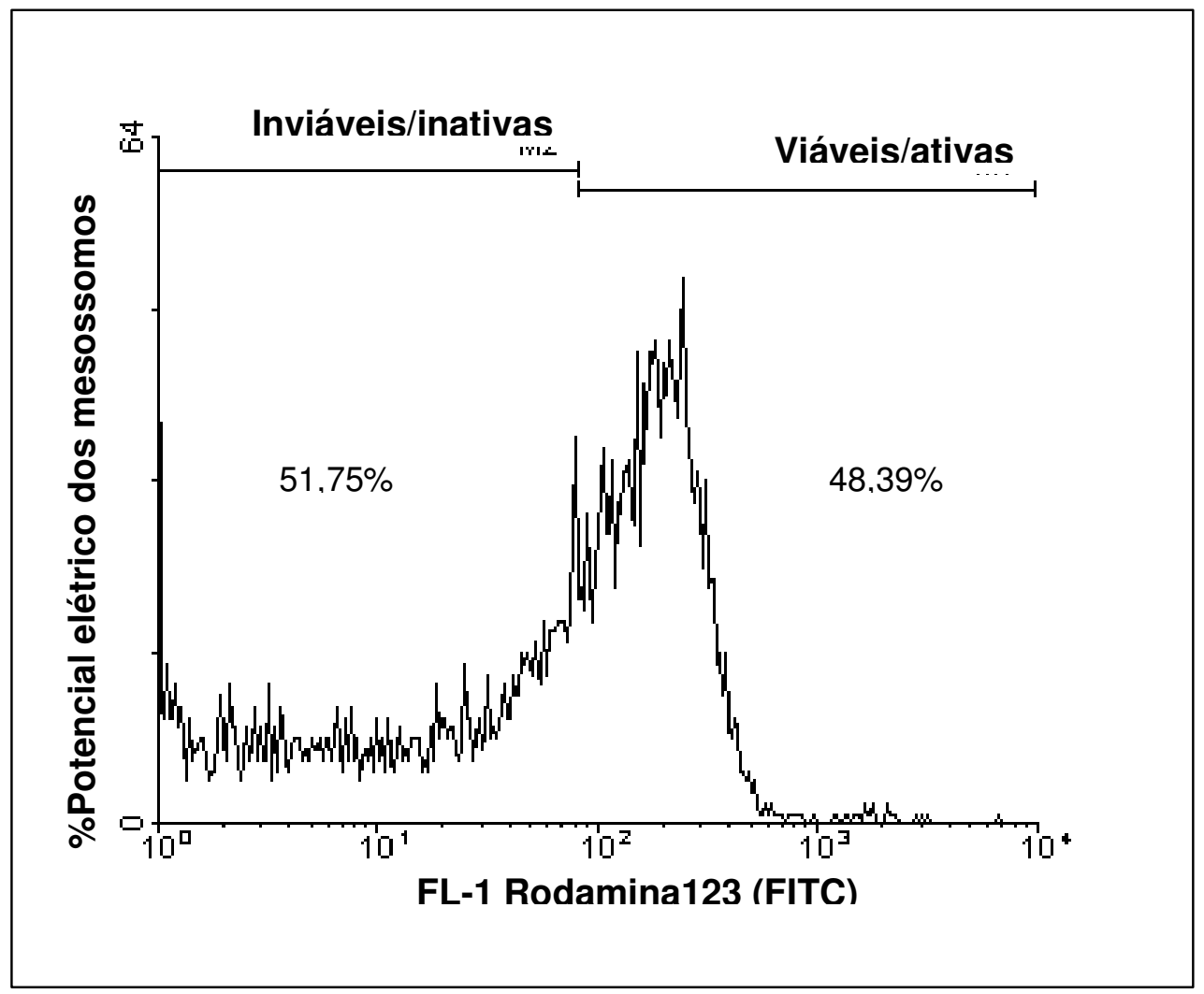

Figura 24 - Viabilidade da bactéria Bacillus subtilis de contato com DL-50/241 Am por $5 \mathrm{~h}$.

\subsection{Resultados de biorremoção}

\subsubsection{Biorremoção por Ochrobactrum anthropi}

As figuras 25, 26 e 27 apresentam os resultados dos experimentos de biarremoção realizados com Ochrobactrum anthropi, Cupriavidus metallidurans e Bacillus subtilis, respectivamente.

Os experimentos com Ochrobactrum anthropi, figura 25, revelaram um processo de biorremoção muito eficiente e rápido, pois foi observada remoção média de $95 \%$ já a partir de 2 minutos de contato e em todas as concentrações estudadas. Este comportamento se manteve praticamente constante até 24 horas. A tabela 5 apresenta os resultados obtidos dos experimentos de biorremoção com Ochrobactrum anthropi. 


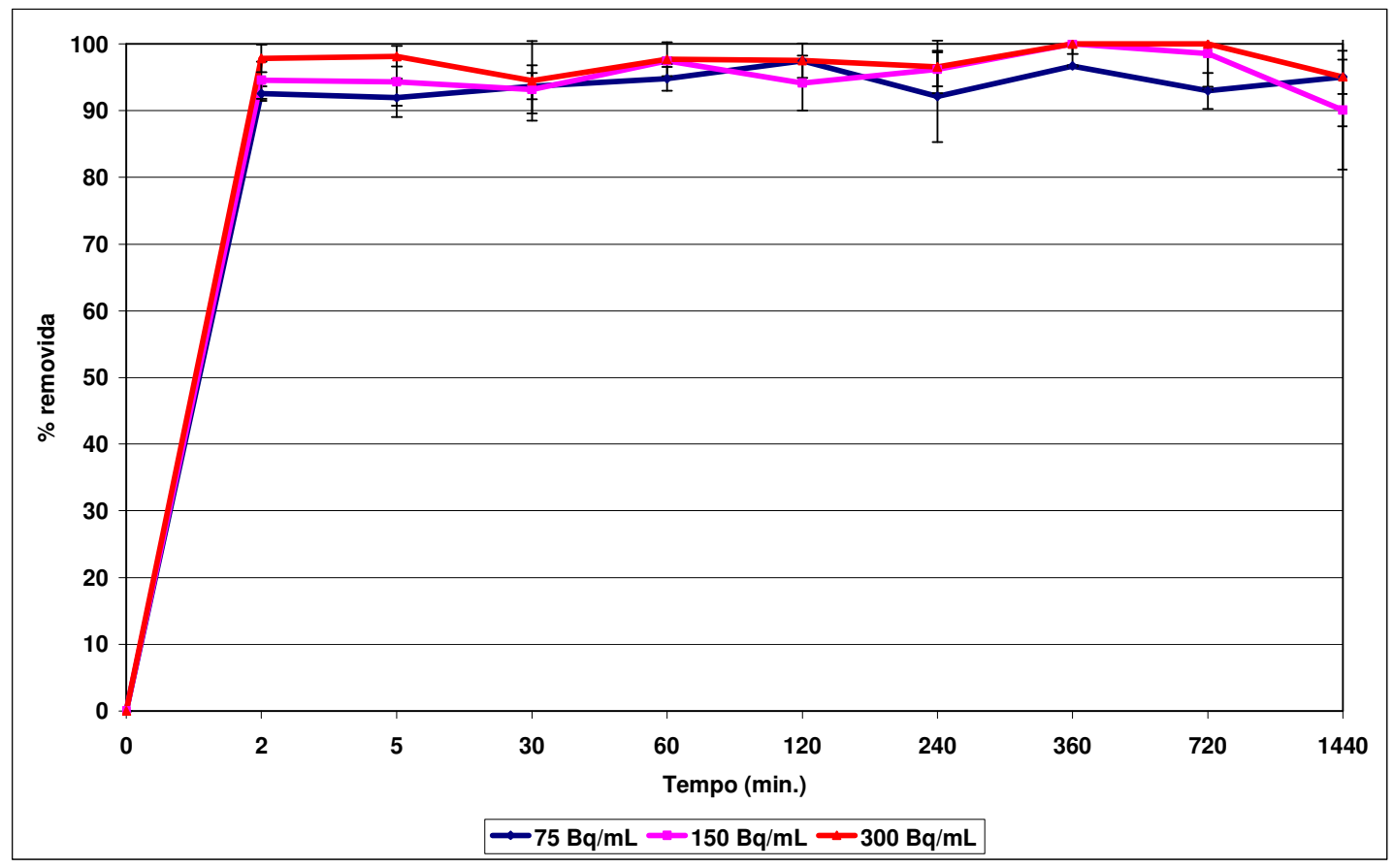

Figura 25. Biorremoçãode ${ }^{241}$ Am com concentrações iniciais de 75, 150 e 300 $\mathrm{Bq} / \mathrm{mL}$ por Ochrobactrum anthropi.

\begin{tabular}{|c|c|c|c|}
\hline $\begin{array}{c}\text { Tempo } \\
\text { (min.) }\end{array}$ & $75 \mathrm{Bg} / \mathrm{mL}$ & $150 \mathrm{Bg} / \mathrm{mL}$ & $300 \mathrm{Bg} / \mathrm{mL}$ \\
\hline 2 & $92,5+1,0$ & $94,5+2,7$ & $97,8+2,0$ \\
\hline 5 & $91,9+2,8$ & $94,3+3,5$ & $98,2+1,5$ \\
\hline 30 & $93,6+1,9$ & $93,2+3,6$ & $94,5+5,9$ \\
\hline 60 & $94,8 \pm 1,7$ & $97,5 \pm 0,5$ & $97,7 \pm 2,5$ \\
\hline 120 & $97,5 \pm 0,2$ & $94,1 \pm 4,1$ & $97,5 \pm 2,5$ \\
\hline 240 & $92,1 \pm 6,8$ & $96,2 \pm 2,5$ & $96,6 \pm 3,9$ \\
\hline 360 & $96,7 \pm 0,1$ & $100 \pm 1,5$ & $100 \pm 3,3$ \\
\hline 720 & $92,9 \pm 2,7$ & $98,6 \pm 5,4$ & $100 \pm 6,3$ \\
\hline 1440 & $95,1 \pm 2,6$ & $90,1 \pm 8,9$ & $95,1 \pm 7,4$ \\
\hline
\end{tabular}

\subsubsection{Biorremoção por Cupriavidus metallidurans}

Nos experimentos de biorremoção de ${ }^{241} \mathrm{Am}$ com concentrações de 75, 150 e $300 \mathrm{~Bq} / \mathrm{mL}$, por Cupriavidus metallidurans CH34 (figura 26), foram removidos, em média, $90 \%$ do ${ }^{241} \mathrm{Am}$ na primeira hora de contato e, em 6 horas de contato a remoção a média chega a 99,6\% para todas as concentrações de ${ }^{241} \mathrm{Am}$ estudadas. A tabela 6 apresenta os resultados obtidos dos experimentos de biorremoção de ${ }^{241} \mathrm{Am}$ por Cupriavidus metallidurans. 


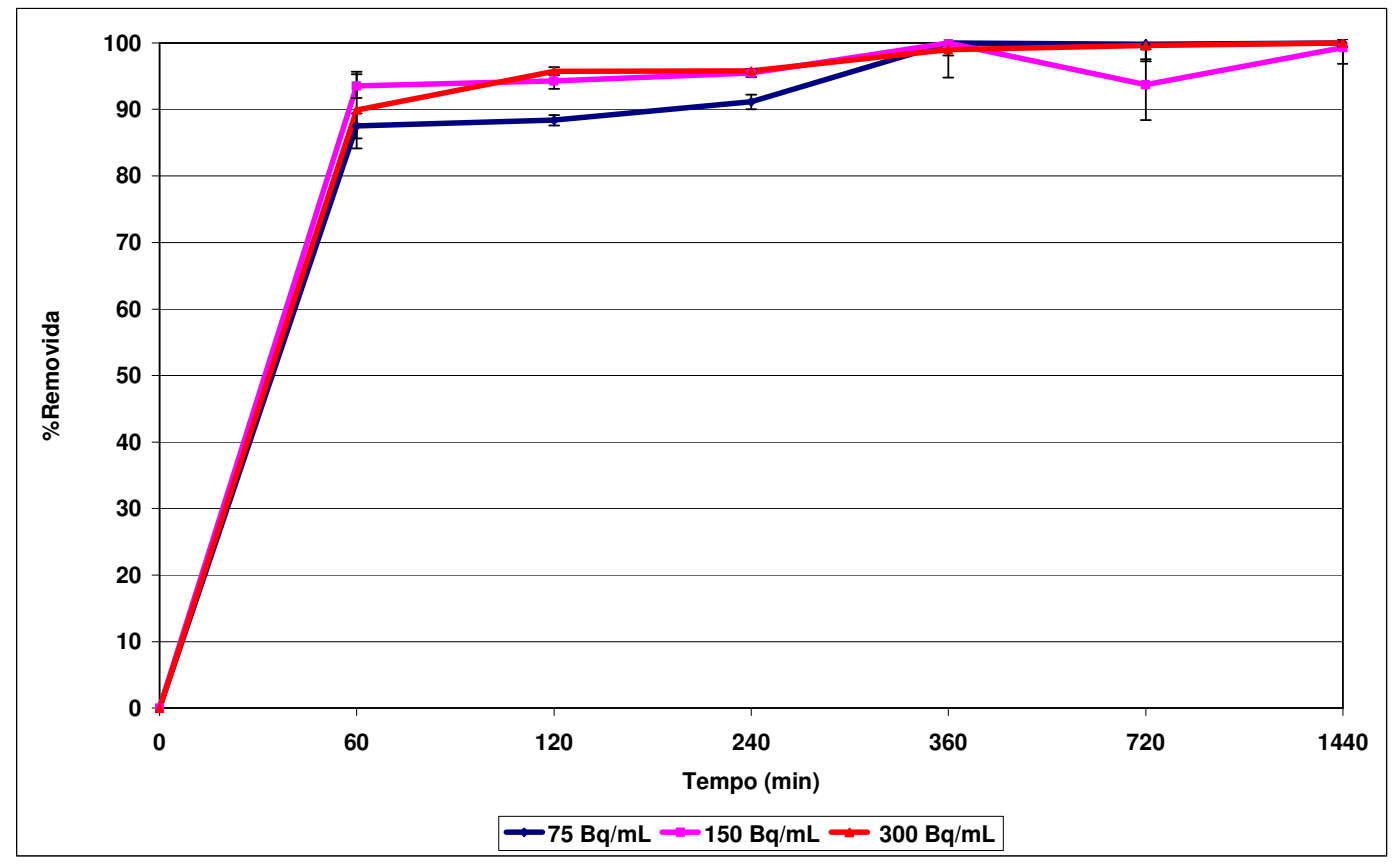

Figura 26. Biorremoção de ${ }^{241}$ Am com concentrações iniciais de 75, 150 e 300 $\mathrm{Bq} / \mathrm{mL}$ por Cupriavidus metallidurans.

Tabela 6 - Biorremoção de ${ }^{241}$ Am por Cupriavidus metallidurans.

\begin{tabular}{cccc}
\hline \hline $\begin{array}{c}\text { Tempo } \\
(\min )\end{array}$ & $75 \mathrm{~Bq} / \mathrm{mL}$ & $150 \mathrm{~Bq} / \mathrm{mL}$ & $300 \mathrm{~Bq} / \mathrm{mL}$ \\
60 & $87,5 \pm 1,9$ & $93,5 \pm 1,8$ & $89,9 \pm 5,8$ \\
120 & $88,4 \pm 0,8$ & $94,2 \pm 1,7$ & $95,7 \pm 0,6$ \\
240 & $91,1 \pm 1,1$ & $95,4 \pm 0,6$ & $95,8 \pm 0,3$ \\
360 & $100 \pm 1,8$ & $100 \pm 0,8$ & $98,9 \pm 4,2$ \\
720 & $99,8 \pm 2,6$ & $93,7 \pm 5,3$ & $99,5 \pm 2,0$ \\
1440 & $100 \pm 0,6$ & $99,2 \pm 2,4$ & $100 \pm 0,5$ \\
\hline \hline
\end{tabular}

\subsubsection{Biorremoção por Bacillus subtilis}

Os resultados obtidos com os experimentos de biorremoção de ${ }^{241} \mathrm{Am}$ por Bacillus subtilis mostraram que em 6 horas de contato, a biorremoção foi de 25,4\%, em média e, em 12 horas de contato a remoção subiu, atingindo o máximo $52,3 \%$ de remoção para solução com $150 \mathrm{~Bq} / \mathrm{mL}$. Após este período, houve um decréscimo de remoção, sugerindo um processo de dessorção (figura 27). A 
tabela 7 apresenta os resultados obtidos dos experimentos de biorremoção de ${ }^{241}$ Am por Bacillus subtilis.

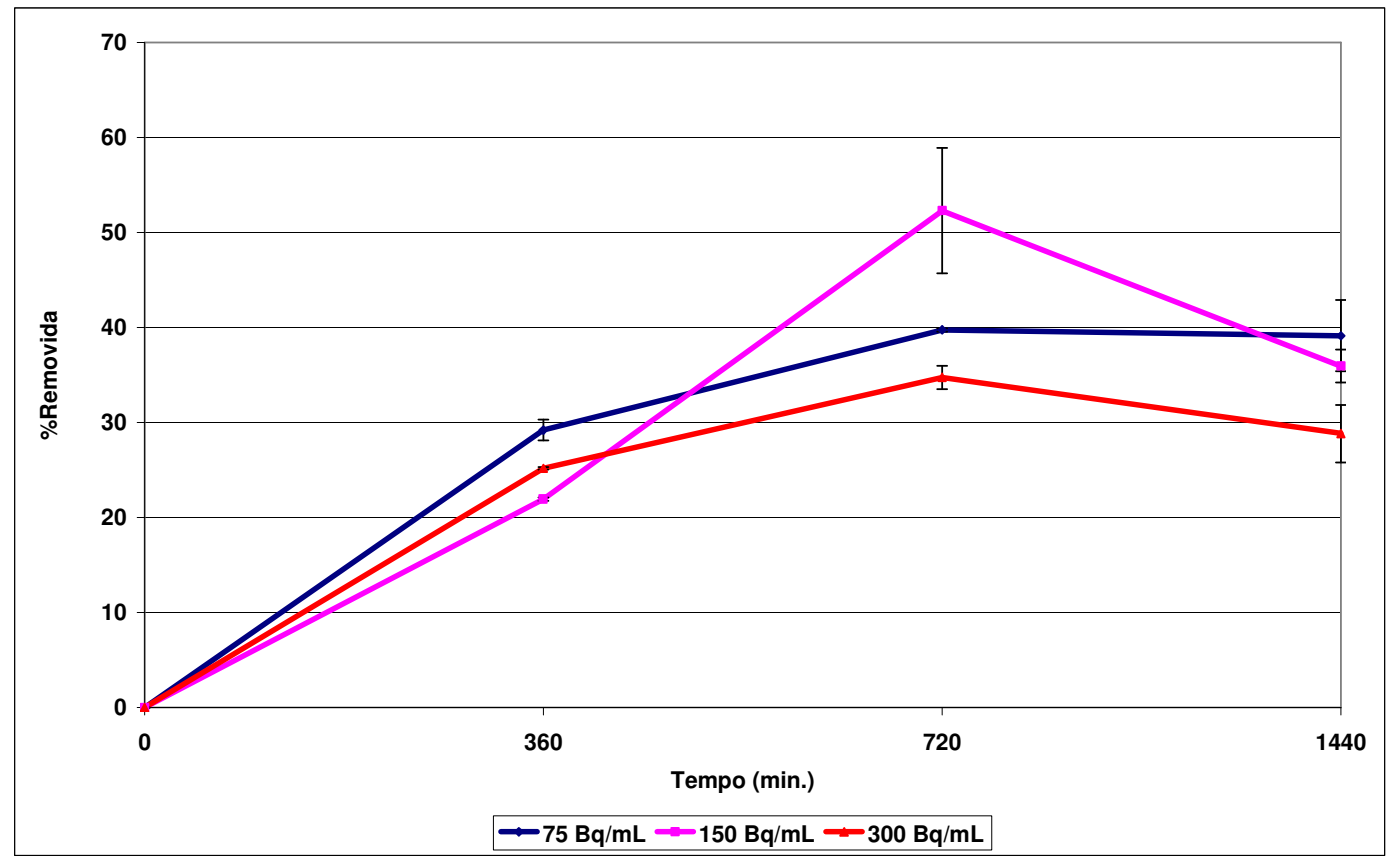

Figura 27. Biorremoção de ${ }^{241}$ Am com concentrações iniciais de 75, 150 e 300 $\mathrm{Bq} / \mathrm{mL}$ por Bacillus subtilis.

Tabela 7 - Resultados da biorremoção de ${ }^{241}$ Am por Bacillus subtilis.

\begin{tabular}{cccc}
\hline \hline $\begin{array}{c}\text { Tempo } \\
\text { (min) }\end{array}$ & $75 \mathrm{~Bq} / \mathrm{mL}$ & $150 \mathrm{~Bq} / \mathrm{mL}$ & $300 \mathrm{~Bq} / \mathrm{mL}$ \\
360 & $29,2 \pm 1,1$ & $21,9 \pm 0,2$ & $25,2 \pm 0,1$ \\
720 & $39,7 \pm 0,2$ & $52,3 \pm 6,6$ & $34,7 \pm 1,2$ \\
1440 & $39,13 \pm 3,7$ & $35,9 \pm 1,7$ & $28,8 \pm 3,0$ \\
\hline \hline
\end{tabular}

Os resultados dos experimentos de bioacumulação de ${ }^{241} \mathrm{Am}$ por Bacillus subtilis (bactéria Gram-positiva) foram bem inferiores aos resultados observados com as duas bactérias Gram-negativas (Ochrobactrum anthropi e Cupriavidus metallidurans). 
Estes resultados são corroborados por Hu (1992), que justifica o fato de as bactérias gram-negativas apresentarem maior capacidade de adsorção do que as bactérias gram-positivas, devido ao maior teor de lipídios da parede celular.

A figura 28 mostra, a título de curiosidade, a redução de volume e mudança de estado físico proporcionada pelo uso das micro esferas de alginato de cálcio em solução de ${ }^{241} \mathrm{Am}$. O volume inicial de $22 \mathrm{~mL}$ de solução foi reduzido a 17,6 $\mathrm{mg}$, ou seja, ocorreu uma redução de 99,92\% do volume inicial.

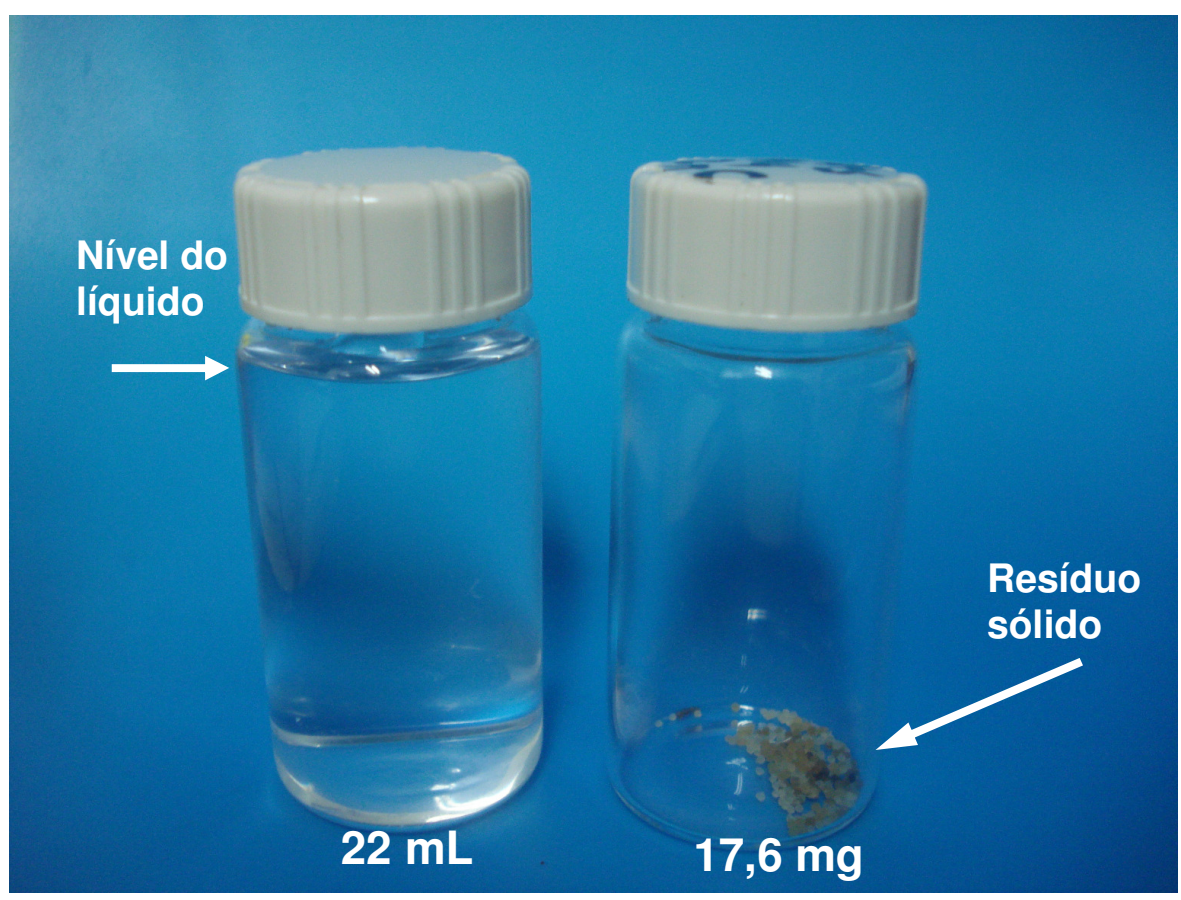

Figura 28 - Redução de volume e mudança de estado físico do rejeito líquido contendo ${ }^{241} \mathrm{Am}$, utilizando-se micro esferas de alginato de cálcio. 


\section{CONCLUSÕES}

Saccharomyces cerevisiae livres inativadas por radiação realizam o processo de biossorção com mais eficiência na solução de ${ }^{241} \mathrm{Am}$ em pH 2 do que em pH 4 e, quanto maior a atividade de amerício presente na solução estudada, menor a porcentagem de biossorção.

Quando imobilizadas em alginato de cálcio, as células de Saccharomyces cerevisiae são capazes de remover valores muito próximos de $100 \%$ do ${ }^{241} \mathrm{Am}$ em solução de pH 4, a partir de 1 hora de contato, independente da concentração das soluções estudadas.

As micro esferas de alginato de cálcio sem levedura têm desempenho muito semelhante ao apresentado por Saccharomyces cerevisiae imobilizadas em alginato de cálcio.

As cepas das bactérias estudadas Ochrobactrum anthropi foi a cepa que se mostrou mais eficiente, sendo capaz de remover, média, 95\% do radionuclídeo em apenas 2 minutos de contato e, em média, 97\% em 60 minutos de contato, independente da concentração estudada.

Cupriavidus metallidurans remove em média, $90 \%$ em 1 hora de contato e 100\% em 6 horas de contato independente da atividade estudada.

Bacillus subtilis apresentou menor capacidade de remoção de ${ }^{241} \mathrm{Am}$, removendo, no máximo, $52,3 \%$ para solução com atividade de $150 \mathrm{~Bq} / \mathrm{mL}$. Sendo assim, as duas bactérias Gram negativas apresentaram melhores resultados de remoção de ${ }^{241} \mathrm{Am}$.

Pela técnica de citometria de fluxo foi possível demonstrar que além da bioacumulação, também ocorreu biossorção por células inviáveis

De todos os biossorventes estudados, o biopolímero alginato de cálcio apresenta melhor trabalhabilidade, visto que pode ser removido facilmente do rejeito líquido além de apresentar alta capacidade de remoção de ${ }^{241} \mathrm{Am}$ e proporcionar uma grande redução de volume $99,9 \%$. 


\section{SUGESTÕES PARA TRABALHOS FUTUROS}

Estudar os mecanismos de biossorção e bioacumulação do ${ }^{241} \mathrm{Am}$ pelas bactérias Ochrobactrum anthropi e Cupriavidus metallidurans.

Definir as isotermas de sorção de todas as biomassas estudadas neste trabalho.

Testar a imobilização das biomassas contendo ${ }^{241} \mathrm{Am}$ em cimento para deposição final destes rejeitos já reduzidos.

Estudar a possibilidade de recuperação do ${ }^{241} \mathrm{Am}$.

Testar as biomassas utilizadas neste trabalho para a biorremoção em rejeitos reais contendo variados radionuclídeos. 


\section{REFERÊNCIAS BIBLIOGRÁFICAS}

ADAMIS, P. D. B.; PANEK, A.D.; LEITE, S. G. F.; ELEUTHERIO, E.C.A. Factors involved with cadmium absorption by a wild-type strain of Saccharomyces cerevisiae. Brazilian Journal of Microbiology, v. 34, p. 55-60, 2003.

ADAMS, B. A.; HOLMS, E. L. Adsorptive properties of synthetic resins. I. J. Soc. Chem. Znd., n.54, p.1-6T, 1935.

AHALYA, N.; RAMACHANDRA, T.V. and KANAMADI, R.D. Biosorption of heavy metals. Research Journal of Chemistry and Environment, v. 7, p. 71-78, 2003.

AKHTAR, K., M. WAHEED AKHTARB, AHAMD M. KHALIDC, Removal and recovery of zirconium from its aqueous solution by Candida tropicalis. Journal of Hazardous Materials, v.156, p. 108-117, 2008.

AL-SARAJ, M.; ABDEL-LATIF, M.S.; EL-NAHAL, I.; BARAKA, R. Bioaccumulation of some hazardous metals by sol-gel entrapped microorganisms. Journal of NonCrystalline Solids, v. 248, p.137-140, 1999.

APARICIO, S. Chromium biosorption by the algal biomass Sargassum sp. 45p. Master of Science ProGramme - Department of Kemioch metallurgi, Division of Kemisk teknologi, Luleà University of Techonology, 2000.

ARAÚJO, F. F. Seed inoculation with Bacillus subtilis, formulated with oyster meal and growth of corn, soybean and cotton. Ciência Agrotec, v. 32 n.2, 2008.

ARIEF, V.O.; TRILESTARI, K.; SUNARSO, J.; INDRASWATI, N.; ISMADJI, S. Review: Recent Progress on Biosorption of Heavy Metals from Liquids Using Low Cost Biosorbents: Characterization, Biosorption Parameters and Mechanism Studies. Clean Journal, v. 32, p. 937-962, 2008.

ATBACK, R., BOUNIOL, P., VITORGE, P. Cement use for radioactive waste embedding and disposal purposes. Cement and Concrete Research, v. 22, 419429, 1992.

ATKINSON, B.W.; KASAN, H.C. Considerations for application of biosorption technology to remediate metal-contaminated industrial effluents, Water SA v. 24, n. 2, ISSN 0378-4738, 1998.

BANERJEE, A. and NAYAK, D. Biosorption of no-carrier-added radionuclides by calcium alginate beads using 'tracer pocket' technique. Bioresourse Technology v. 98 p. 2771-1774, 2007. 
BASÍLIO, M. S.; FRIESI, K.; DE LENA, J. C.; NALINI Jr., H. A.; ROESER, H. M. $\mathrm{P}$. Adsorção de As, $\mathrm{Cu}, \mathrm{Pb} \mathrm{E}$ Cr na avaliação da capacidade de fixação de metais por resíduo de mineradoras de ferro. Química Nova, v. 28, p. 822, 2005.

BAYAN, Y.K.;KESKINLER, B.;CAKICE,A. LEVENT M.;AKAY, G. Removal of divalent heavy metal mixtures from water by Saccharomyces cerevisiae using crossflow micofiltration. Water Resourse v. 35, p. 2191, 2001.

BEEK, B. Bio-accumulation: new aspects and developments. The book of Environmental Chemistry. Springer-Verlag Berlin-Heidelberg, 2000.

BENEDICT, M.; PIGFORD, H.P.; LEVI, H. W. Nuclear Chemical Engineering, $2^{\text {nd }}$ ed., McGraw-Hill Book Comp., p.465, 1981.

BEVERIDGE, J. T.; MURRAY, R. G. E.Uptake and retention of metals by cell walls of Bacillus subtilis. Journal of Bacteriology, v.127, n. 3 p.1502-1518, 1976.

BIONDO, R. Engenharia genética de Cupriavidus metallidurans $\mathrm{CH} 34$ para a biorremediação de efluentes contendo metais pesados. Tese apresentada ao ProGrama de Pósgraduação Interunidades em Biotecnologia EP/ FMVZ /IPT /IB /ICB / Butantan da Universidade de São Paulo para obtenção do título de Doutor em Biotecnologia., 2008.

BRADY, D. and DUNCAN, J.R. Bioaccumulation of metal-cations by Saccharomyces cerevisiae. Applied Microbiology and Biotechnology, v. 41 p. 149-154, 1984.

BREIEROVÁ, E.; VAJCZIKOVÁ, I.; SASINKOVÁ, E.; FISERA, M.; GREGOR, T.; SAJBIDOR, J. Biosorption of cadmium ions by different yeast species. Zeitschrift Naturforch, v.57, p.634-639, 2002.

BRIERLEY, C.L. Bioremediation of metal-contaminated surface and ground waters. Geomicrobiology Journal, v. 8, p. 201-23, 1990.

BROCK, T. D.; MADIGAN, M. T.; MARTINCO, J. M.; PARKER, J. Biology of Microrganisms, $7^{\mathrm{a}}$ Ed. New Jersey, Prentice Hall, p. 909, 1994.

BUSTARD, M.; MCHALE, A. P. Biosorption of uranium by cross-linked and alginate immobilized residual biomass from deistillery spent wash. Bioprocess Engineering v.17, p.127-130, 1997.

CANIZARES-VILLANUEVA, R. O., Biosorción de metales pesados mediante el uso de biomassa microbiana. Revista Latinoamericana de Microbiologia v. 42, p. 131-143, 2000.

CHENG, Y., YAN, F.; HUANG, F.; CHU, W.; PAN, D.; CHEN, Z.; ZHENG, J.; YU, M.; LIN, Z.; WU, Z. Bioremediation of $\mathrm{Cr}$ (IV) and Immobilization as $\mathrm{Cr}$ (III) by Ochrobactrum anthropi. Envirn. Sci. Technology, n. 44, p. 6357-6363, 2010. 
CHOJNACKA, K. Bosorption and bioaccumulation - the prospects for practical applications. Environmental International, v. 36, p. 299-307, 2010.

CLAIN, A. F.; AQUINO, J. O. Recuperação de ${ }^{241} \mathrm{Am}$ de para raios e detectores de fumaça. Química Nova, v. 22, p. 677-678, 1999.

COMISSÃO NACIONAL DE ENERGIA NUCLEAR, "Licenciamento de Instalações Radiativas" - CNEN-NE-6.02, Rio de Janeiro 1985.

COSSICH, E.S.; TAVARES, C.R.G.; SILVA, E.A., RAVAGNANI, T.M.K. Biossorção de Cromo (III) pela biomassa de alga marinha Sargassum sp. Tese apresentada para obtenção do grau de Doutor da Faculdade de Engenharia Química Universidade Estadual de Campinas, 2000.

COSTA, A. C. A.; DUTA, F. P. Bioaccumulation of copper, zinc, cadmium and lead by Bacillus sp., Bacillus cereus, Bacillus sphaericus and Bacillus subtilis. Brazilian Journal of Microbiology, v. 32, p. 1-5, 2001.

DAS, S. K., KEDARI, C. Z., SHINDE, S. S., GHOSH, S., JAMBUNATHAN, U. Performance of immobilized Saccharomyces cerevisiae in the removal of long lived radionuclides from aqueous nitrate solutions. J. Radioanalytical and Nuclear Chemistry, v. 253, n.2, p. 235-240, 2002.

DHAMI, P. S.; KANNAN, R. ; NAIK, P. W.; DAS, S. K.; GOPALAKRISHNAN, V.; RAMANUJAM, A.; SALVI, N. A.; CHATTOPADHYAY, S. Biosorption of Americium using Various Biomasses of Rhizopus Species, Biotechnology Letters, p. 885889, 2004.

EIDE, D. J. The molecular biology of metal ion transport in Saccharomyces cerevisiae.

Annual Review of Nutrition, v.18, p. 441-469, 1998.

EHRLICH, H. L. Geomicrobiology, $2^{\text {nd }}$ ed rev. Marcel/dekker Inc. New York, 1990.

FALDYNA, M.; LEVA, L.; KNOTGOVA, P.; TOMAN, M. Lymphocyte subsets in peripheral blood of dogs - a flow cytometric study. Veterinary Immunology and Immunopathology, v.82, p. 23-37, 2001.

FENG, D.; ALDRICH, C.; Adsorption of heavy metals by biomaterials derived from the marine alga Ecklonia maxima. Hydrometallurgy, v. 73, p. 1, 2004.

FERREIRA, R. V. P.; MARUMO, J. T., BELLINI, M. H., POTIENS, A. J., TAKARA, A. S., GOES, M. M., BORBA, T. R., NASCIMENTO, C. M., SAKATA, S. K. Use of Saccharomyces cerevisiae in radioactive waste treatment. International Nuclear Atlantic Conference - INAC, 2007.

FERREIRA, R. V. P.; SAKATA, S. K.; ISIKI, V. L. K.; MIYAMOTO, H.; BELLINI, M. H.; LIMA, L. F. C. P.; MARUMO, J. T. Influence of americium-241 on the microbial population and biodegradation of organic waste. Environmental Chemistry Letters, 2009. 
GADD, G.M.; MOWLL, J.L.; WHITE, C. Fifth International Conference on Heavy Metals in the Environment Athens, v. 2, p.37, 1985.

GADD, G. M. Microbial interactions with tributyltin compounds: detoxification, accumulation, and environmental fate. The Science of The Total Environment, v. 258, p. 119-127, 2000.

GOK, C.; AYTAS, S. Biosorption of uranium (IV) from aqueous solution using calcium alginate beads. Journal of Hazardous Materials, v.168, p. 369-375, 2009.

GÖKSUNGUR, Y.; UREN, S.; GUVENÇ, U. Biossorption of cooper ions by caustic treated waste baker's yeast biomass. Turkish Journal of Biology, v. 27, p. 2329, 2003.

GOMES, L.H.; DEL RIO, D.T.; DUARTE, K.M.R., ANDRINO, F.G.; TAVARES, F.C.A. Biossorção de cádmio por leveduras Saccharomyces cerevisiae, ICTR, 2006.

GOMES, L. H. ; ALEXANDRINO, N. ; DUARTE, K.M. R.; ANDRINO, F. G. ; TAVARES, F.C. A .Imobilização de Saccharomyces cerevisiae em diferentes suportes visando o tratamento de efluentes contaminados com cádmio. In: Anais do 15o SIICUSP, 2007.

GRINDEM, C. B. Blood cell markers. Veterinary Clinics of North America: Small Animal Practice, Philadelphia, v. 26, n. 5, p. 1043-1065, 1996.

HU, T. L. Sorption of reactive dyes by Aeromonas biomass. Water Science Technology, v. 26, p. 357-366, 1992.

HUANG, P. M.; BOLLAG, J. M.; SENESI, N. Interactions between soil particles and microorganisms: impact on the terrestrial ecosystem, John Wiley and Sons. Press, 2002.

IBÁÑEZ, J.P.; UMETSU, Y.; Potential of protonated alginate beads for heavy metals uptake. Hidrometallurgy, v. 64, p. 89-99, 2002.

IBÁÑEZ, J.P.; UMETSU; Uptake of trivalent chromium form aqueous solution using protonated dry alginate beads. Hydrometallurgy, v. 72, p. 227-234, 2004.

INTERNATIONAL ATOMIC ENERGY AGENCY . Radioactive waste management glossary. $2^{\text {nd }}$ ed. Vienna, (IAEA - TECDOC - 447) 1988.

INTERNATIONAL ATOMIC ENERGY AGENCY Classification of radioactive waste - General safety guide. Vienna, 2009.

ITOH, M.; YUASA, M.; KOBAYASHI, T. Adsorption of metal ions on yeast cells at varied cell concentration. Plant Cell Physiology, v.16, p.1167-1169, 1975. 
JEPRAS, R. I.; CARTE, J.; PEARSON, S. C.; PAUL, F. E.; WILKINKSON, M. J. Development of a robust flow cytometry assay for determining numbers of viable bacteria. Applied and Environmental Microbiology, v. 61, n. 7, p. 2696-2701, 1995.

KAÇAR, Y.; ARPA, Ç.; TAN, S.; DENIZLI, A.; GENÇ, Ö.; ARICA, Y. M. Biosorption of $\mathrm{Hg}(\mathrm{II})$ and $\mathrm{Cd}(\mathrm{II})$ from aqueous solutions: comparison of biosorptive capacity of alginate and immobilized live and heat inactivated Phanerochaete chysosporium. Process Biochemistry, v. 37, p. 601-610, 2002.

KADUKOVÁ, J, VIRCÍKOVÁ, E. Comparison of differences between copper bioaccumulation and biosorption. Environmental International v. 31, p. 277-232, 2005.

KAPOOR, A.; VIRARAGHAVAN, T.; CULLIMORE, D. R. Removal of heavy metals using the fungus Aspergillus niger. Bioresour Technology, v. 70, p. 95, 1999.

KAPOOR, A.; VIRARAGHAVAN, T. Fungi biosorption-an alternative treatment option for heavy metal bearing wastewaters: a review. Bioresour Technol; v. 53, p.195-206, 1995.

KEDARI, C. S.; DAS, S. K.; GOSH, S. Biosorption of long lived radionuclides using immobilized cells of Saccharomyces cerevisiae Journal of Microbiology \& Biotechnology, v. 17, p. 789, 2001.

KELLER, C. The Chemistry of the Actinide Elements; Verlag /Chemie Gmbh, Weinhein, 1971.

KIRAN, I., AKAR, T., TUNALI, S. Biosorption of PB(II) and $\mathrm{Cu}$ (II) from aqueous solutions by preteated biomass of Neurospora crassa. Process Biochemistry, $\mathrm{v}$. 40, p.3550-3558, 2005.

KLIS, F. M.; MOL, P.; HELLINGWERF, K.; BRUL, S. Dynamics of cell wall structure in Saccharomyces cerevisiae. FEMS Microbiology Reviews, v. 26, p.239-256 2002.

KOTRBA, P.; DOLECKOVÁ, L.; LORENZO, V.; RUML, T. Enhanced Bioaccumulation of Heavy Metal lons by Bacterial Cells Due to Surface Display of Short Metal Binding Peptides. Applied and Environmental Microbiology, v. 65, n. 3, p. 1092-1098, 1999.

KOURKOUTAS, Y.; BEKATOROU, A.; BANAT, I.M.; MARCHANT, R.; KOUTINAS, A.A. Immobilization technologies and support materials suitable in alcohol baverages production: a review. Food Microbiology, v. 1, p. 377-397, 2004.

KRATOCHVIL D., VOLESKY, B. Advances in the biosorption of heavy metals.Trends Biotechnology, v.16, n. 7, p. 291-300, 1998. 
LEE, S. S., ROBINSON, F.M., WANG, H.Y. Rapid determination of yeast viability Biotechnology and Bioenineering. Symposium., v. 11 p. 641-649, 1981.

LI, B.; PAN, D.; ZHENG, J.; CHENG, Y.; MA, X.; HUANG, F.; LIN, Z. Microscopic Investigations of the $\mathrm{Cr}(\mathrm{IV})$ Uptake Mechanism of Living Ochrobactrum anthropi. Langmuir, n. 24, p. 9630-9635, 2008.

LIAO, J.; YANG, Y.; LOU, S.; LIU, N.; JIN, J.; ZHANG, T.; ZHAO, P., Biosorption of americium-241 by immobilized Rhizopus arrihizus. Applied Radiation and Isotopes, v. 60, p. 1-5, 2004.

LIMA, A. M. F. Estudo das propriedades físico-químicas do alginato de sódio, pectina e blendas em solução e no estado sólido para aplicação em sistemas de liberação de fármacos. Tese apresentada para obtenção do título de doutora em química da Universidade Federal de Santa Catarina, 2006.

LIU, N; YANG, Y.; LOU, S.; ZHANG, T.; JIN, J.; LIAO, J.; HUA, X. Biosorption of ${ }^{241}$ Am by Rhizopus arrihizus: preliminary investigation and evaluation. Applied Radiation and Isotopes, v. 57, p. 139-143, 2002(a).

LIU, N.; LOU, S.; YANG, Y.; ZHANG, Y.; JIN, J.; LIAO, J. Biosorption of americium-241 by Saccharomyces cerevisiae. Journal of Radionalytical and Nuclear Chemistry, v. 252, n.1, p. 187-191, 2002(b).

LIU, N. ; LIAO, J.; LUO, S.; YANG Y.; JIN, J.; ZHANG, T.; ZHAO, P. Biosorption of ${ }^{241} \mathrm{Am}$ by immobilized Saccharomyces cerevisiae Journal Radional. Nucl. Chem., v. 258, p. 59, 2003.

LLOYD, J. R. Microbial reduction of metals and radionuclides, FEMS Microbiology, v. 27, p. 411-425, 2003.

LLOYD, J. R., RENSHAW, J.C. Microbial transformations of radionuclides: fundamental mechanisms and biogeochemical implication. Met. Ions Biol. Syst., v. 44 p. $205-240,2005$.

LOU, S.; LIU, N.; YANG, Y; ZHANG, T.; JIN, J.; LIAO, J. Biosorption of americium241 by Candida sp, Radiochimica Acta, v. 91, n. 6, p. 315-318, 2003.

LUK'YANOVA, E. A.; ZAKHAROVA, E. V.; KONSTANTINOVA, L. I.; NAZINA, T. $\mathrm{N}$. Sorption of radionuclides by microorganisms from a deep repository of liquid low-level waste. Radiochemistry, v. 50, n. 1, p. 85-90, 2008.

MADIGAN, M. T.; MARTINKO, J. M.;PARKER, J. Microbiologia de Brock, Prentice Hall, 2008.

MARUMO, J.T. Difusão de cloretos e ataque por sulfatos em pastas e argamassas de cimento Portland. Dissertação para obtenção de grau de Mestre em Ciências na Área de Reatores Nucleares de Potência e Tecnologia do Combustível - IPEN/CNEN, 1997. 
MARUMO, J. T. Avaliação da contaminação provocada por pára-raios radioativos de Amerício-241 descartados em lixões. Tese apresentada para obtenção do grau de Doutor em Ciências na Área de Tecnologia Nuclear Materiais - IPEN/CNEN, 2006.

MACHADO, M. D.; JANSSENS, S.; SOARES, H. M.V.M. and SOARES, E. V. Removal of heavy metals using a brewer's yeast strain of Saccharomyces cerevisiae: advantages of using dead biomass. Bioresource Technology, v. 99, p. 2107-2115, 2008.

MALIK, A. Metal bioremediation through growing cells. Environment International v. 30, p. 261-278, 2004.

MARTINSEN, A.; STORRO, I.; SKJAK-BROEK,G. Alginate as immobilization material: III. Diffusional properties. Biotechnology and Bioengineering, v. 39, p.186-194, 1992.

MATSUMURA, T.; USUDA, S. Applicability of insoluble tannin to treatment of waste containing americium. Journal of Alloys and Compounds, v. 271-273, p. 244-247, 1998.

MEENA, K.; RAJA, T.K. Immobilization of Saccharomyces cerevisiae cells by gel entrapment using various metal alginates. World Journal of Microbiology v. 22, p.651-652, 2006.

MERGEAY, M.; NIES, D.; SCHLEGEL, H.G.; GERITS, J.; CHARLES, P.; GIJGESEM, VAN. Alcaligenes eutrophus $\mathrm{CH} 34$ is a Facultative Chemolithotroph with Plasmid-Bound Resistance to Heavy Metals. Journal of Bacteriology, v. 162, p 338-324, 1985.

MERGEAY, M.; MONCH, S.; VALLAEYS, T.; AUQUIER, V. BENOTMANE, A; BERTIN, P.; DUNN, J.; TAGHAVI, S.; LELIE, D. V.D.; WATTIEZ, R. Ralstonia metallidurans, a bacterium specifically adapted to toxic metals: towards a catalogue of metal-responsive genes. FEMS Microbiology Reviews, v. 27, p385410, 2003.

MERROUN, M. L.; SELENSKA-POBELL, S. Bacterial interactions with uranium: An environmental perspective. Journal of Contamination Hydrology, v. 102, p.285-295, 2008.

MIMURA, H.; OHTA, H.; AKIBA, K.; ONODERA, Y. Uptake behavior of americium on alginic acid and alginate polymer gels. Journal of Radioanalytical and Nuclear Chemistry, v. 247, p. 33-38, 2001.

MIMURA, H.; OHTA, H.; AKIBA, K.; ONODERA Removal of radioactive nuclides by multi-functional microcapsules enclosing inorganic íon-exchangers and organic extractants. WM Conference, Tucson, AZ, 2002. 
MIRANDA, L. E. T.; VICENTE, R. Processo para a gestão de pára-raios radioativos no Brasil. Instituto de Pesquisas Energéticas e Nucleares. Departamento de Rejeitos Radioativos. São Paulo, 1999.

MONCHY, S.; VALLAEYS, T.; BOSSUS, A.; MERGEAY, M. Metal transport ATPase genes from Cupriavidus metallidurans $\mathrm{CH} 34$ : a transcriptomic approach. Int. J. Environ. Anal. Chem., v. 86, p. 677-692, 2006.

MONCHY, S. ; BEN OTMANE, M. A.; JANSSEN, P.; VALLAEYS, T.; TAGHAVI, S.; LELIE, D. V. D; MERGEAY, M. Plasmids pMOL28 and pMOL30 of Cupriavidus metallidurans are specialized in the maximal viable response to heavy metals. Journal of Bacteriology, v. 189, p. 7417-7425, 2007.

MOURA, L. A. A. Proposta de Implantação de um Sistema de Gestão Ambiental no Laboratório de Rejeitos Radioativos do IPEN/SP - Dissertação apresentada como parte dos requisitos para obtenção do grau de Mestre em Ciências na Área de Tecnologia Nuclear - Aplicações, 2008.

MURALEEDHARAN, T.R; LVENGAR, L. VENKOBACHAR. Biosorption: an attractive alternative for metal removal and recovery. Curr. Scien., v. 61, p. 379-381, 1991.

NAKAJIMA, A., SAKAGUCHI, T. Selective accumulation of heavy metals by microorganisms. App. Microbiol. Biotechnol., v. 24, p. 59-64, 1986.

NATIONAL COMMITTEE FOR CLINICAL LABORATORY STANDARDS. Metodologia dos Testes de Sensibilidade a Agentes Antimicrobianos por Diluição para Bactéria de Crescimento Aeróbico. 6 ed. Villanova: NCCLS, 2003. .Disponível em:<http:/www.anvisa.gov.br/reblas/reblas_publicacoes_bac_cresc. pdf>. Acesso em: 23 ago. 2009.

NAYAK, D.; LAHIRI, S. Biosorption of toxic, heavy, no-carrier-added radionuclides by calcium alginate beads. Journal of Radioanalytical and Nuclear Chemistry, v. 267, p. $59-65,2005$.

OLIVEIRA, L. P. Seleção e aproveitamento biotecnológico de frutos encontrados na Amazônia para elaboração de bebida alcoólica fermentada utilizando levadura imobilizada. Tese apresentada ao proGrama de pósgraduação da Universidade Federal do Amazonas para a obtenção do título de doutor em biotecnologia, área de concentração Ciências Agrárias, 2006.

ÖNAL, S.; BAYSAL, S. H.; OZDEMIR, G. Studies on application of alginateentrapped Chryseomonas luteola TEM 05 for heavy metal biosorption. Journal of Hazardous Materials, v.146, p. 417-420, 2007.

OZDEMIR, D.; SOYPACACI, Z.; SAHIN, I.; BICIK, Z.; SENCAN, I. Ochrobactrum anthropi Endocarditis and Septic Shock in a Patient in no Prosthetic Valve or Rheumatic Heart Disease: Case Report and Review of the Literature. Jpn. J. Infect. Dis., n. 59, p. 254-265, 2006. 
OZDEMIR, G.; OZTURK, T., CEYTHAN, N.; ISLER, R.; COSAR, T. Heavy metl biosorption by biomass of Ochrobactrum anthropi producing exoplysaccharide in activated sludge. Bioresource Techonology, n. 90, p. 71-74, 2003.

OZDEMIR, G.; CEYHAN, N.; MANAV, E. Utilization of an exopolysaccharide produced by Chryseomonas luteola TEM05 in alginate beads for adsorption of cadmium and cobalt ions". Biores. Technolology, v. 96, p. 1677-1682, 2005.

PACCEZ, J. D., NGUEYN, H. D., LUIZ, W. B., FERREIRA, R. C. C., SBROGIOALMEIDA, M. E.; SCHUMAN, W.; FERREIRA, L. C. S. Evaluation of different promoter sequences and antigen sorting signals on the immunogenicity of Bacillus subtilis vaccine vehicles. Vaccine, v. 25, p. 4671-4680, 2007.

PAPAGEORGIOU, S. K.; KATSAROS, F. K.; KOUVELOS, E. P. ; NOLA, J. W.; DEIT, H. L.; KANELLOPOULOS, N. K. Heavy metal sorption by alginate beads from Laminaria digitata. Journal of Hazardous Materials, v. 137, p.175-1772, 2006.

PAPAGEORGIOU, S. K.; KOUVELOS, E. P.; KATSARUS, F. K. Calcium alginate beads form Laminaria digitata for the renoval of $\mathrm{Cu}_{+}{ }^{2}$ and $\mathrm{Cd}_{+}{ }^{2}$ from dilute aqueous metal Solutions. Desalination, v. 224, p. 293-306, 2008.

PERRIER, T.; GARIN-MARTIN, A.; MOERELLO. Am-241 remobilization in a calcareous soil under simplified rhiszospheric conditions studied by column experiments. Journal of Environmental Radioactivity, n. 79, p. 205-221, 2005.

RENSHAW, J. C., LLOYD, J. R., LIVENS, R. L., Microbial interactions with actinides and long-lived fission products, C. R. Chimie, v. 10, p. 1067e1077, 2007.

ROZYCKI, T. V.; NIES, D. H., Cupriavidus metallidurans: evolution of a metalresistant bacterium. Antonie van Leeuwenhoek, v. 96, p.115-139, 2009.

SEKHAR, K.C.; KAMALA, C.T., CHARY, N.S.; ANJANEYULU, Y. Removal of heavy metals using a plant biomass with reference to environmental control, Int. J. Process v. 68, p.37-45, 2003.

SELEEM, M. N.; ALI, M.; BOYLE, S. M.; MUKHOPADHYAY, WITONSKY, S. G.; SCHURING, G.G.; SRIRANGANATHAN, N. Establishment of a Gene Expression System in Ochrobactrum anthropi. Appl. Environ. Microbiol, n. 72., v. 10, p. 6833-6836, 2006.

STRINGFELLOW, W.T.; KOMADA, T.; CHANG, L.-Y. Biological treatment of concentrated hazardous, toxic, and radionuclide mixed wastes without dilution, Ernest Orlando Lawrence Berkeley National Laboratory Formal Report No. LBNL-55928 Berkeley National Laboratory, Berkeley, CA, USA., 2000. 
TAKENAKA, Y.; SAITO, T.; NAGASAKI, S.; TANAKA, S. Metal sorption to Pseudomonas fluorescens: influence of $\mathrm{pH}$, sonic strength and metal concentrations, Geomicrobiology Journal, v. 24, p. 205-210, 2007.

TEIXEIRA, J. A.; ARAÚJO, M. M. Remoção de crômio de efluentes industriais utilizando géis de alginato. V CONFERÊNCIA NACIONAL SOBRE A QUALIDADE DO AMBIENTE, 5, Aveiro, 1996. v.. 2. ISBN 972-569-088-5. Disponível em:< http://hdl.handle.net/1822/3846 >, acesso em 20/02/2010.

TSEZOS, M.; BELL, J. P. I.. Significance of biosorption for the hazardous organics removal efficiency of a biological reactor. Water Res. 22:391-394, 1988.

TSEZOS, M.; Biosorption of metals. The experience accumulated and the outlook for technology development. Hydrometallurgy, v. 59, p. 241-243, 2001.

VECCHIO, A.; FINOLI, C.; DI SIMINE, D. Heavy metal biosorption by bacterial cells. Fresenius J. Anal Chem., v. 361, p. 338-342, 1998.

VEGLIÓ, F.E; BEOLCHINI, F. Removal of metals by biosorption: a review. Hydrometallurgy, v. 44, p. 301-316, 1997(a).

VEGLIÓ, F.; BEOLCHINI, F.; GASBARRO, A.; Biosorption of toxic metals: an equilibrium study using free cells of Athrobacter sp. Process Biochemistry, v. 32, p.99-105, 1997(b).

VEGLIÓ, F; ESPOSITO, A.; REVERBERI, A. P. Copper adsorption on calcioum alginate beads: equilibrium $\mathrm{Ph}$ - related models. Hydrometallurgy, v. 65, p. 43-57, 2002.

VELÁSQUEZ, L.; DUSSAN, J. Biosorption and bioaccumulation of heavy metals on dead and living biomass of Bacillus sphaericus. Journal of Hazardous Materials, doi:10.1016/j.jhazmat.2009.01.44, 2009.

VELINGS, N.M.; MESTDAGH, M.M. Phisyco-Chemical Properties of Alginate Gel Beads. Polymer Gels and Netwrks, v. 3, p. 311-330, 1995.

VENKOBACHAR, C., IYENGA, L., MISHRA, U. K., CHAUHAN, M. S. Release of $\mathrm{U}(\mathrm{VI})$ form spent biosorbent immobilized in cement concret blocks. Cement and Concret Research, v. 25, p. 1639-1646, 1995.

VIEIRA, R.H.S.F.; VOLESKY, B. Biosorption: a solution to pollution? Internatinonal Microbiology, v. 3, p. 17-24, 2000.

VIJAYARAGHAVAN, K. and YUN, Y.S. Bacterial biosorbents and biosorption. Biotechnology Advances, v. 26, p. 266-291, 2008.

VOLESKY, B. Biosorption and biosorbents. In: Volesky B., editor Biosrption of Heavy Metals. Florida: CRC press; 1990. 
VOLESKY, B.; MAY, H.; HOLAN, Z.R. Cadmium biosorption by Saccharomyces cerevisiae - Biotechnology and Bioengineering, v. 41, p. 345-355, 1993.

VOLESKY, B. Advances in biosorption of metals: selection of biomass types. FEMS Microbiol, Rev., v.14, p. 291-302, 1994.

VOLESKY, B.; MAY-PHILLIPS, H.A Biosorption of heavy metals by Saccharomyces cerevisiae. Journal Applied Microbiology Biotechnology, $\mathrm{n}$. 42, p. 797-806, 1995.

VOLESKY, B.; HOLAN Z.R. Biosorption of heavy metals. Biotechnology Prog., v. 11, p. 235-250, 1995.

VOLESKY, B.; CHONG, H. K. Description of Two-Metal Biosorption Equilibria by Langmuir-Type Models. Biotechnology and Bioengineering, v. 47, p. 451-460, 1995.

VOLESKY, B. Detoxification of metal-bearing effluents: biosorption for the next century. Hydrometallurgy, v. 59, p. 203-216, 2001.

VOLESKY, B. Biosorption and me. Water Res., v. 41, p. 4017-4029, 2007.

WANG J.; CHEN, C.. Biosorption of heavy metals by Saccharomyces cerevisiae: A review. Biotechnology Advances, v. 24, p. 427, 2006.

WEST, J.M.; McKINLEY, I.G.; STROES-GASCOYNE, S. Microbial Effects on Waste Repository Materials. In: Keith-Roach, M., Livens, F. (Eds.), Interactions of microorganisms with radionuclides. Elsevier Sciences, Oxford. UK, p. 255-277, 2002.

WILKERSON, M. J. Principles of flow cytometry and cell sorting. In: $55^{\text {th }}$ Annual Meeting of the American College of Veterinary Pathologists (ASVCP), 2004.

YAMAURA, M. Determinação de tório em soluções do processo thorex por espectometria de fluorescência de raios $-X$. Dissertação para obtenção de grau de Mestre em Ciências na Área de Reatores Nucleares de Potência e Tecnologia do Combustível - IPEN/CNEN, 1982. 